Technical Report

March 1993

\title{
The Subduction Experiment
}

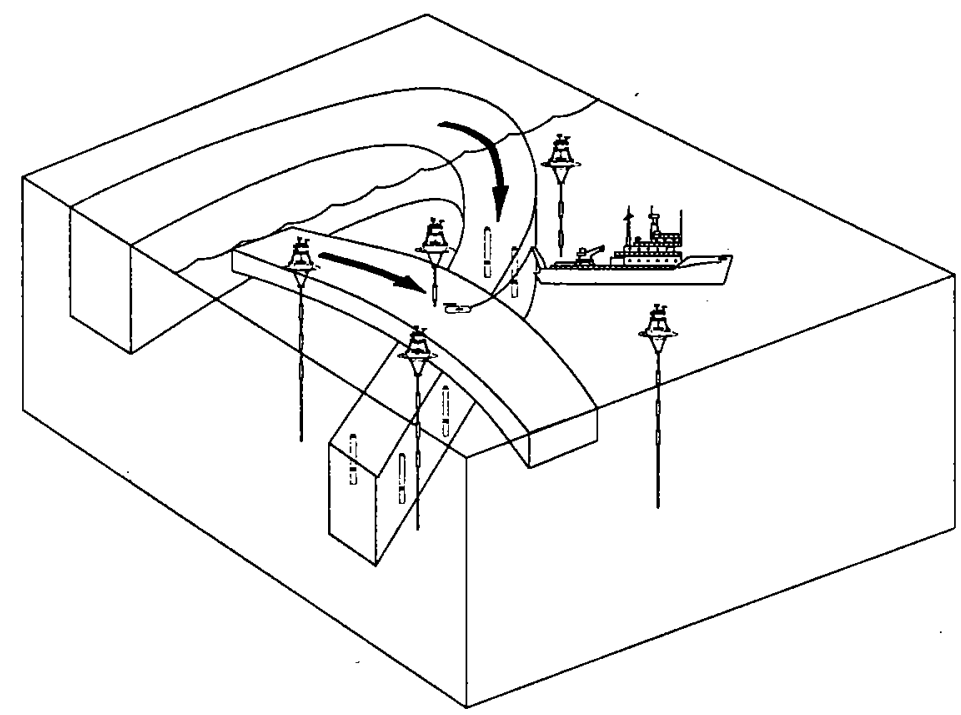

Cruise Report

R/V Oceanus

Cruise Number 250 Legs 1 and 2

Subduction 2 Mooring Deployment and Recovery Cruise

25 January - 26 February 1992

by

Richard P. Trask Nancy J. Brink Lloyd Regier Neil McPhee

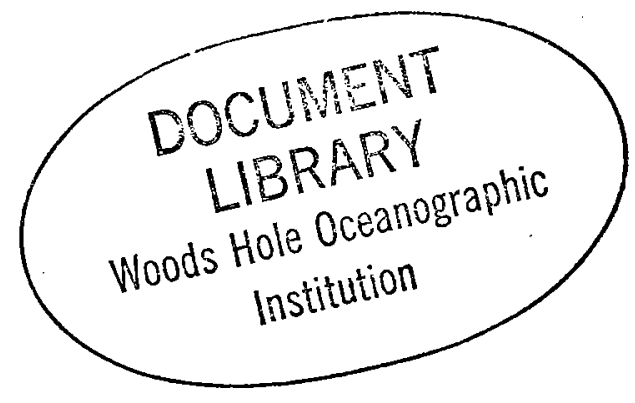


WHOI-93-13

UOP Report 93-2

\title{
The Subduction Experiment \\ Cruise Report \\ R/V Oceanus
}

Cruise Number 250 Legs 1 and 2

Subduction 2 Mooring Deployment and Recovery Cruise

25 January - 26 February 1992

by

\author{
Richard P. Trask \\ Nancy J. Brink \\ Lloyd Regier \\ Neil McPhee
}

Upper Ocean Processes Group

Woods Hole Oceanographic Institution

Woods Hole, Massachusetts 02543

March 1993
Technical Report

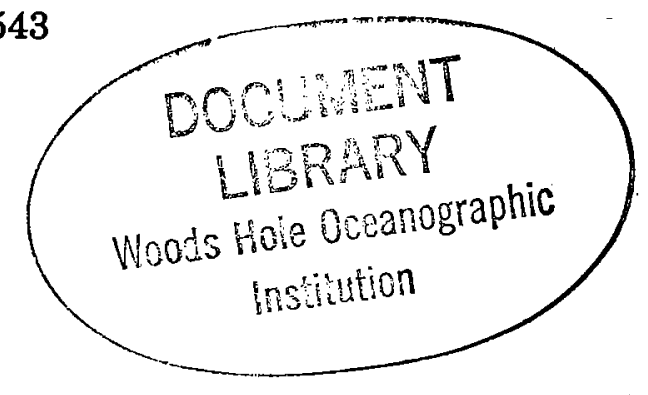

Funding was provided by the Office of Naval Research under contract N00014-90-J-1490.

Reproduction in whole or in part is permitted for any purpose of the

United States Government. This report should be cited as:

Woods Hole Oceanog. Inst. Tech. Rept., WHOI-93-13.

Approved for publication; distribution unlimited.

Approved for Distribution:

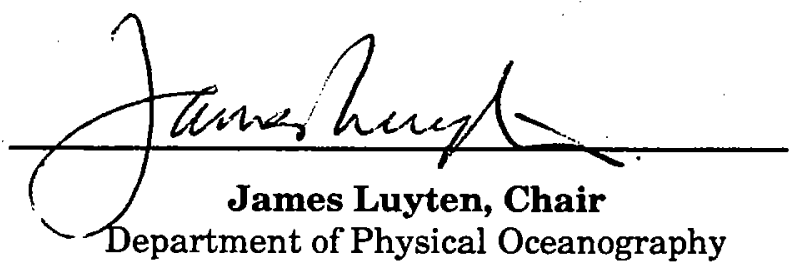





\begin{abstract}
Subduction is the mechanism by which water masses formed in the mixed layer and near the surface of the ocean find their way into the upper thermocline. The subduction process and its underlying mechanisms were studied through a combination of Eulerian and Langrangian measurements of velocity, measurements of tracer distributions and hydrographic properties and modeling.

An array of five surface moorings carrying meteorological and oceanographic instrumentation were deployed for a period of two years beginning in June 1991 as part of an Office of Naval Research (ONR) funded Subduction experiment. Three eight month deployments were planned. The moorings were deployed at $18^{\circ} \mathrm{N} 34^{\circ} \mathrm{W}, 18^{\circ} \mathrm{N} 22^{\circ} \mathrm{W}, 25.5^{\circ} \mathrm{N} 29^{\circ} \mathrm{W}$, $33^{\circ} \mathrm{N} 22^{\circ} \mathrm{W}$ and $33^{\circ} \mathrm{N} 34^{\circ} \mathrm{W}$.
\end{abstract}

A Vector Averaging Wind Recorder (VAWR) and an Improved Meteorological Recorder (IMET) collected wind speed and wind direction, sea surface temperature, air temperature, short wave radiation, barometric pressure and relative humidity. The IMET also measured precipitation. The moorings were heavily instrumented below the surface with Vector Measuring Current Meters (VMCM) and single point temperature recorders.

Expendable bathythermograph (XBT) data were collected and meteorological observations were made while transitting between mooring locations.

This report describes the work that took place during $\mathrm{R} / \mathrm{V}$ Oceanus cruise number 250 which was the second scheduled Subduction mooring cruise. During this cruise the first setting of the moorings were recovered and redeployed for a second eight month period. This report includes a description of the instrumentation that was deployed and recovered, has information about the underway measurements (XBT and meteorological observations) that were made including plots of the data and presents a chronology of the cruise events. 


\section{Table of Contents}

\section{page}

List of Figures $\quad 3$

List of Tables $\quad 5$

$\begin{array}{ll}\text { Section 1: Introduction } & 6\end{array}$

$\begin{array}{ll}\text { Section 2: The Mooring Program } & 8\end{array}$

A. Moorings and Buoys $\quad 8$

$\begin{array}{ll}\text { B. Instrumentation } & 12\end{array}$

C. Underway Measurements 16

$\begin{array}{ll}\text { Section 3: Chronological Log } & 17\end{array}$

$\begin{array}{ll}\text { References } & 39\end{array}$

$\begin{array}{ll}\text { Acknowledgments } & 39\end{array}$

$\begin{array}{ll}\text { Appendix 1: Cruise Participants } & 40\end{array}$

Appendix 2: SIO Mooring Designs 41

Appendix 3: IMET Buoy System $\quad 44$

Appendix 4: Wind Direction Comparison Tests 47

Appendix 5: ALACE Deployments

Appendix 6: XBT Data $\quad 54$

Appendix 7: IMET Shipboard System Comparison with Manual Observations 97

Appendix 8: ADCP Data Files 99

$\begin{array}{ll}\text { Appendix 9: Chronological Log } & 100\end{array}$ 


\section{List of Figures}

page

$\begin{array}{lr}\text { Figure 1. Mooring Cruise Schedule } & 6\end{array}$

Figure 2. Oceanus 250 ship track and mooring positions 9

Figure 3. Instrument Positions on Subduction 1 Moorings 10

Figure 4. Instrument Positions on Subduction 2 Moorings 11

$\begin{array}{ll}\text { Figure 5. Subduction } 1 \text { Southwest Mooring Schematic } & 18\end{array}$

Figure 6. Subduction 2 Southwest Mooring Schematic 20

Figure 7. Subduction 2 Southwest Acoustic Release Survey 21

Figure 8. Subduction 1 Southeast Mooring Schematic 23

- Figure 9. Subduction 2 Southeast Mooring Schematic 24

Figure 10. Subduction 2 Southeast Acoustic Release Survey 26

Figure 11. Subduction 1 Central Mooring Schematic 27

Figure 12. Subduction 2 Central Mooring Schematic 29

Figure 13. Subduction 2 Central Acoustic Release Survey 30

Figure 14. Subduction 1 Northeast Mooring Schematic 31

$\begin{array}{ll}\text { Figure 15. Subduction } 2 \text { Northeast Mooring Schematic } & 33\end{array}$

Figure 16. Subduction 2 Northeast Acoustic Release Survey 34

Figure 17. Subduction 1 Northwest Mooring Schematic 36

Figure 18. Subduction 2 Northwest Mooring Schematic 37

Figure 19. Subduction 2 Northwest Acoustic Release Survey 38

Figure A4-1. Wind Direction Comparison Tests for the Southwest Buoy 48

Figure A4-2. Wind Direction Comparison Tests for the Southeast Buoy 49

Figure A4-3. Wind Direction Comparison Tests for the Central Buoy 50

Figure A4-4. Wind Direction Comparison Tests for the Northeast Buoy · 51

Figure A4-5. Wind Direction Comparison Tests for the Northwest Buoy 52 


\section{List of Figures (Continued)}

Figure A6-1 a-ee. XBT Profiles in subsets of 10s 55-85

Figure A6-2 a-d. XBT survey area during Oceanus 250 and contour plots 93

Figure A6-3. XBT section locations 94

Figure A6-4 a-b. Contoured XBT sections $\quad$ 95-96

Figure A7-1. IMET shipboard comparison plot vs. manual observations 98 


\section{List of Tables}

page

Table 1. Subduction 1 Deployment and Recovery Information

7

Table 2. Subduction 2 Deployment Information

7

Table 3. Subduction 1 Instrumentation 13

Table 4. Subduction 2 Instrumentation 14

Table A5-1. ALACE Deployment Information 53

Table A6-1. Oceanus 250 XBT Positions 86

Table A8-1. ADCP Data Files $\quad 99$ 


\section{Section 1: Introduction}

R/V Oceanus cruise number 250, Leg 1 departed Woods Hole, Massachusetts, on 25 January 1992 to recover and redeploy five surface moorings as part of the Office of Naval Research (ONR) funded ASTEX and Subduction Experiments. This cruise involved personnel and equipment from both the Woods Hole Oceanographic Institution (WHOI) and Scripps Institution of Oceanography (SIO). Appendix 1 lists the cruise participants.

The first setting of Subduction moorings were deployed in June/July 1991 during Oceanus cruise number 240 (see Trask and Brink, 1993 for details). The first setting has been referred to as Subduction 1. The Subduction 1 moorings were recovered and replaced with 5 new surface moorings during Oceanus cruise 250. The deployment schedule for the entire experiment is shown below (figure 1). Table 1 lists the Subduction 1 mooring positions and the dates they were deployed and recovered. Table 2 lists the deployment positions and dates for the second setting (aka Subduction 2). In addition to the initial deployment and first turnaround cruise a second turnaround cruise in October 92 and the final recovery cruise in June 93 are shown.

This report has in addition to this introduction two other sections. The second section describes the mooring program including the instrumentation that was deployed and recovered, as well as the underway measurements that were made including the XBT and meteorological observations. The third section is a chronology of the entire cruise.

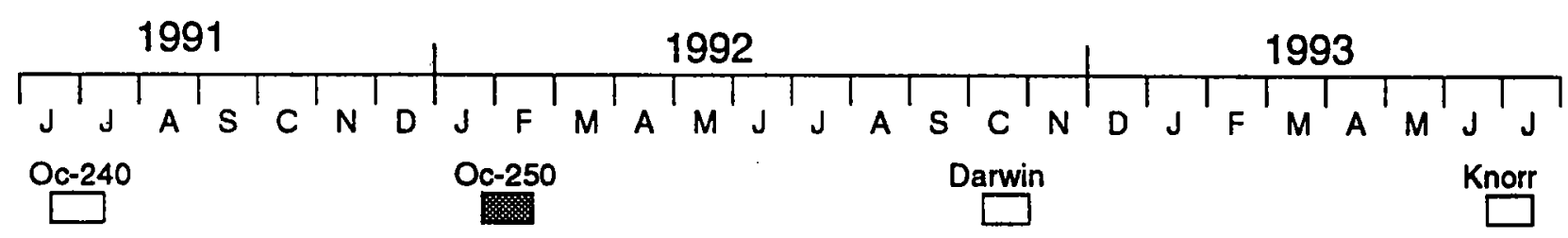

First Setting

Subduction 1

Second Setting

Subduction 2

Third Setting

Subduction 3

Figure 1. Mooring and Cruise Schedule 
Table 1. Subduction 1

\section{Mooring Deployment and Recovery Information}

\begin{tabular}{|c|c|c|c|c|}
\hline Buoy & Mooring \# & $\begin{array}{l}\text { Deployment Time } \\
\text { (UTC) }\end{array}$ & $\begin{array}{l}\text { Recovery Time } \\
\text { (UTC) }\end{array}$ & Position (GPS) \\
\hline NE & 914 & 18 Jun1991 1642 & 14 Feb 19922315 & $\begin{array}{l}33^{\circ} 00.07^{\prime} \mathrm{N} \\
21^{\circ} 59.75^{\prime} \mathrm{W}\end{array}$ \\
\hline $\mathrm{C}$ & 915 & 23 Jun 19910026 & 11 Feb $1992 \quad 1120$ & $\begin{array}{l}25^{\circ} 31.90^{\prime} \mathrm{N} \\
28^{\circ} 57.17^{\prime} \mathrm{W}\end{array}$ \\
\hline SW & 916 & 25 Jun 19911312 & $\begin{array}{l}2 \text { Feb } 19920727 \\
\text { 4 Feb } 19921844^{\circ}\end{array}$ & $\begin{array}{l}18^{\circ} 00.03^{\prime} \mathrm{N} \\
33^{\circ} 59.96^{\prime} \mathrm{W}\end{array}$ \\
\hline SE & 917 & 29 Jun 19910137 & $\begin{array}{l}30 \text { Oct } 19910000 \\
8 \text { Feb } 19920843^{\star *}\end{array}$ & $\begin{array}{l}18^{\circ} 00.13^{\prime} \mathrm{N} \\
22^{\circ} 00.00^{\prime} \mathrm{W}\end{array}$ \\
\hline NW & 918 & 3 Jul 19911323 & $\begin{array}{l}15 \text { Sept } 19912035 \\
23 \text { Feb } 19921022^{* * *}\end{array}$ & $\begin{array}{l}32^{\circ} 54.611^{\prime} \mathrm{N} \\
33^{\circ} 53.50^{\prime} \mathrm{W}\end{array}$ \\
\hline
\end{tabular}

SW Mooring broke free on 3 November 1991. Top 110m recovered 2 February 1992 remainder of mooring recovered 4 February 1992.

- SE Mooring broke free on 10 October 1991. Top 50m recovered on 30 October 1991 remainder of mooring recovered 8 February 1992

NW Mooring broke free on 3 August 1991. Top 400m recovered 15 September 1991 remainder of mooring recovered 23 February 1992

Table 2. Subduction 2

Mooring Deployment Information

\begin{tabular}{|c|c|c|c|}
\hline Buoy: & $\begin{array}{l}\text { Mooring } \\
\text { Number }\end{array}$ & $\begin{array}{l}\text { Deployment Time } \\
\text { (UTC) }\end{array}$ & Position (GPS) \\
\hline SW & 924 & 05 Feb 19921318 & $\begin{array}{l}17^{\circ} 59.93^{\prime} \mathrm{N} \\
34^{\circ} 00.65^{\prime} \mathrm{W}\end{array}$ \\
\hline SE & 925 & 09 Feb 19920244 & $\begin{array}{l}17^{\circ} 59.72^{\prime} \mathrm{W} \\
22^{\circ} 00.29^{\prime} \mathrm{W}\end{array}$ \\
\hline C & 926 & 12 Feb 19921915 & $\begin{array}{l}25^{\circ} 31.95^{\prime} \mathrm{N} \\
28^{\circ} 57.23^{\prime} \mathrm{W}\end{array}$ \\
\hline NE & 927 & 20 Feb 19921547 & $\begin{array}{l}33^{\circ} 01.98^{\prime} \mathrm{N} \\
22^{\circ} 00.27^{\prime} \mathrm{W}\end{array}$ \\
\hline NW & 928 & 23 Feb 19922328 & $\begin{array}{l}32^{\circ} 54.42^{\prime} \mathrm{N} \\
33^{\circ} 53.35^{\prime} \mathrm{W}\end{array}$ \\
\hline
\end{tabular}




\section{Section 2: The Mooring Program}

\section{A. Moorings and Buoys}

The goal of the mooring program conducted during Oceanus cruise number 250 (Oc-250) was to recover five moorings that were deployed during Oceanus cruise $240 \mathrm{leg} 3$ in June/July of 1991, and deploy replacement moorings. The five surface moorings deployed in 1991 included two WHOI discus buoy moorings designated the Northeast and Central moorings and three SIO toroid buoy moorings designated Southwest, Southeast and Northwest. The names of the moorings denote their relative placement in the moored array. Figure 2 shows the location of the individual moorings.

In August 1991 the Northwest mooring parted and the toroid buoy and upper mooring components went adrift. The drifting buoy was subsequently recovered on 15 September during R/V Endeavor cruise number 228. Failure of the Southeast mooring occurred on 10 October 1991. The toroid buoy from this mooring was recovered by the Soviet Research Vessel Mendeleev on 30 October 1991. This was followed by the failure of the Southwest surface mooring which occurred on 3 November 1991. The first stop of Oceanus cruise 250 was to recover the toroid buoy from the Southwest mooring which had drifted 642 miles to the southwest. Appendix 2 describes the SIO mooring designs for Subduction 1 and details the improvements made for Subduction 2.

Since all three of the SIO moorings had failed during the first setting, major design changes were made before the second setting. In addition, the complement of surface buoys was changed such that four of the five moorings deployed during Oc-250 had a WHOI 10' diameter discus buoy as their primary flotation at the surface. The fifth mooring had a SIO 7'6" diameter toroid buoy (from the first setting) for its surface flotation. Additional buoyancy was provided to the toroid by means of a large boat fender that was inserted in the center hole of the toroid and inflated. Figure 3 schematically shows the five Subduction 1 moorings and the distribution of the subsurface instrumentation. Figure 4 shows the five Subduction 2 moorings and their distribution of instrumentation.

Meteorological instrumentation was mounted to both the toroid and discus buoys. A two part aluminum tower was attached to both buoy types. The top half, which had the meteorological sensors, marine lantern and satellite antennae was the same for both buoy types so as to minimize the differences between buoys and to facilitate assembly. The lower half was specific to the buoy type and acted as an interface between the buoy hull and the tower top. The tower tops were separate assemblies so that they could easily be replaced with new units containing freshly calibrated sensors when the moorings were recovered and redeployed.

The two additional discus buoys and one toroid buoy deployed during Oc-250 were prepared in Woods Hole and loaded on Oceanus. These buoys serviced the first three moorings encountered. The toroid was used for the Southwest mooring and the discus' were used on the Southeast and Central moorings. The Central and Northeast discus' deployed in 1991 which were still on station were recovered and taken into Madeira where they were serviced and made ready for use on the Northeast and Northwest moorings. A port stop in Madeira was necessary because the ship could not carry all the equipment for the entire cruise due to deck space and weight limitations. Previous arrangements had been made to ship the equipment needed for the rest of the cruise to Madeira so that it was there when the Oceanus arrived. 
Figure 2. Oceanus 250 ship track and mooring locations.

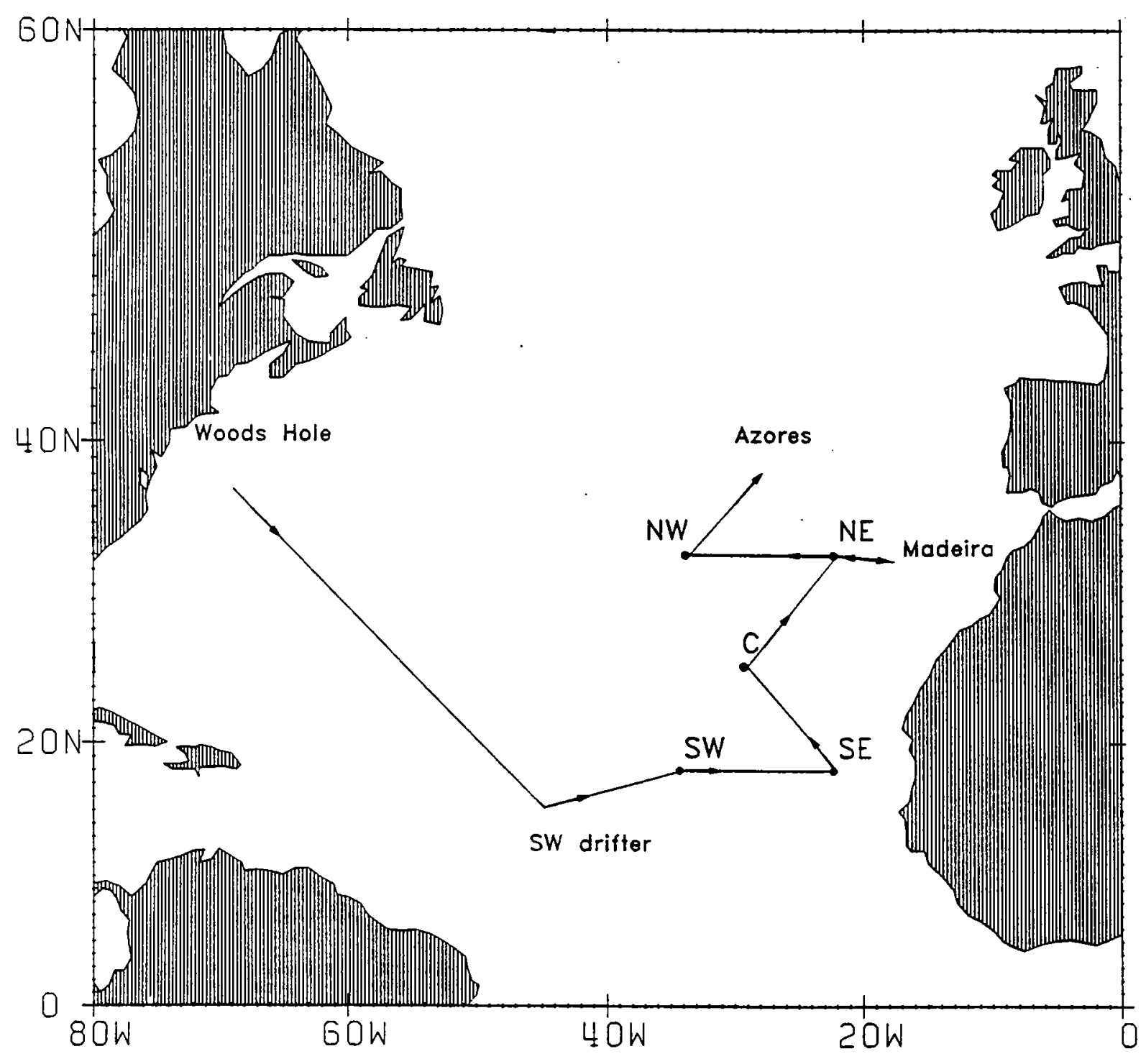


Figure 3. Instrument Positions on the Subduction 1 Moorings

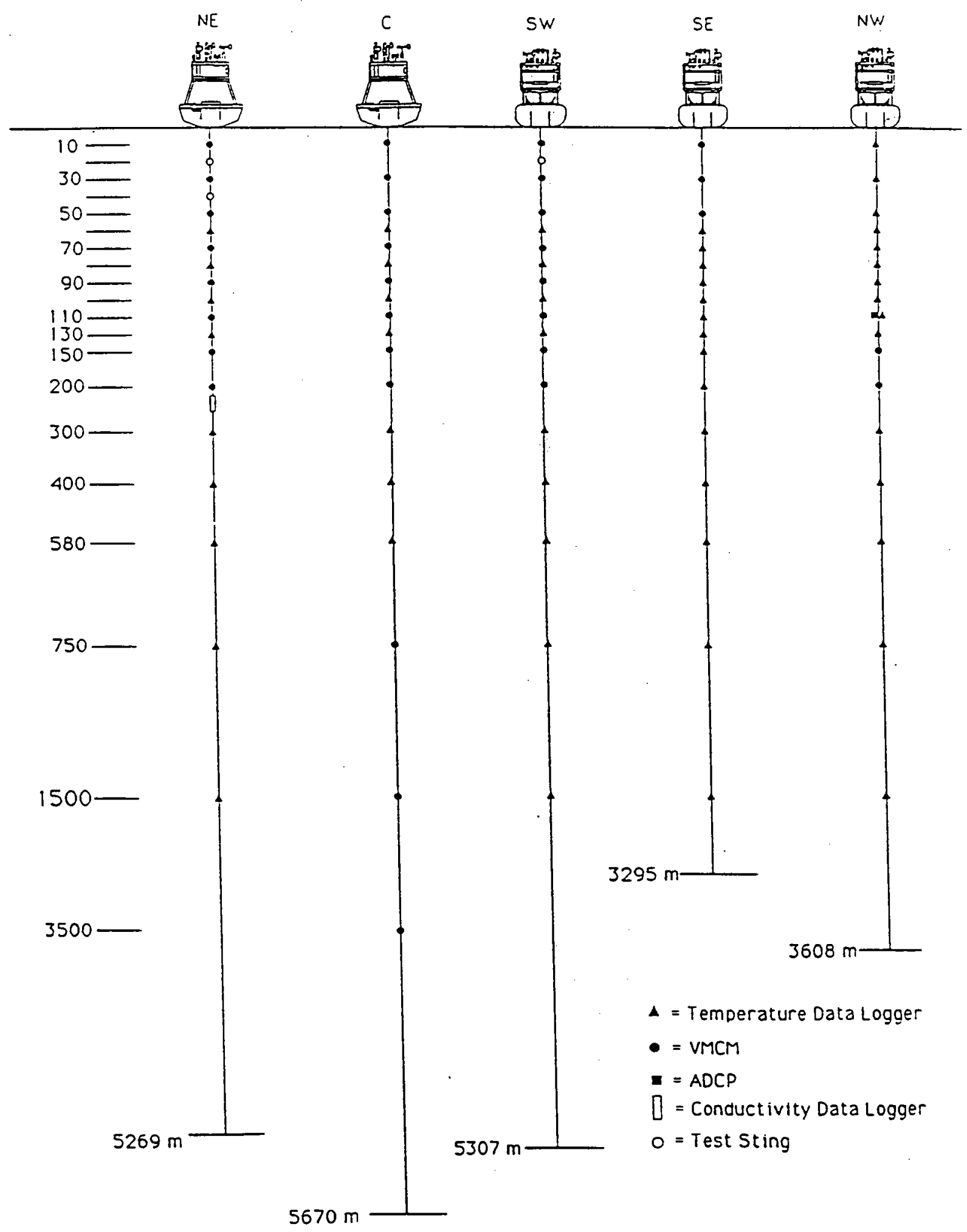


Figure 4. Instrument Positions on the Subduction 2 Moorings

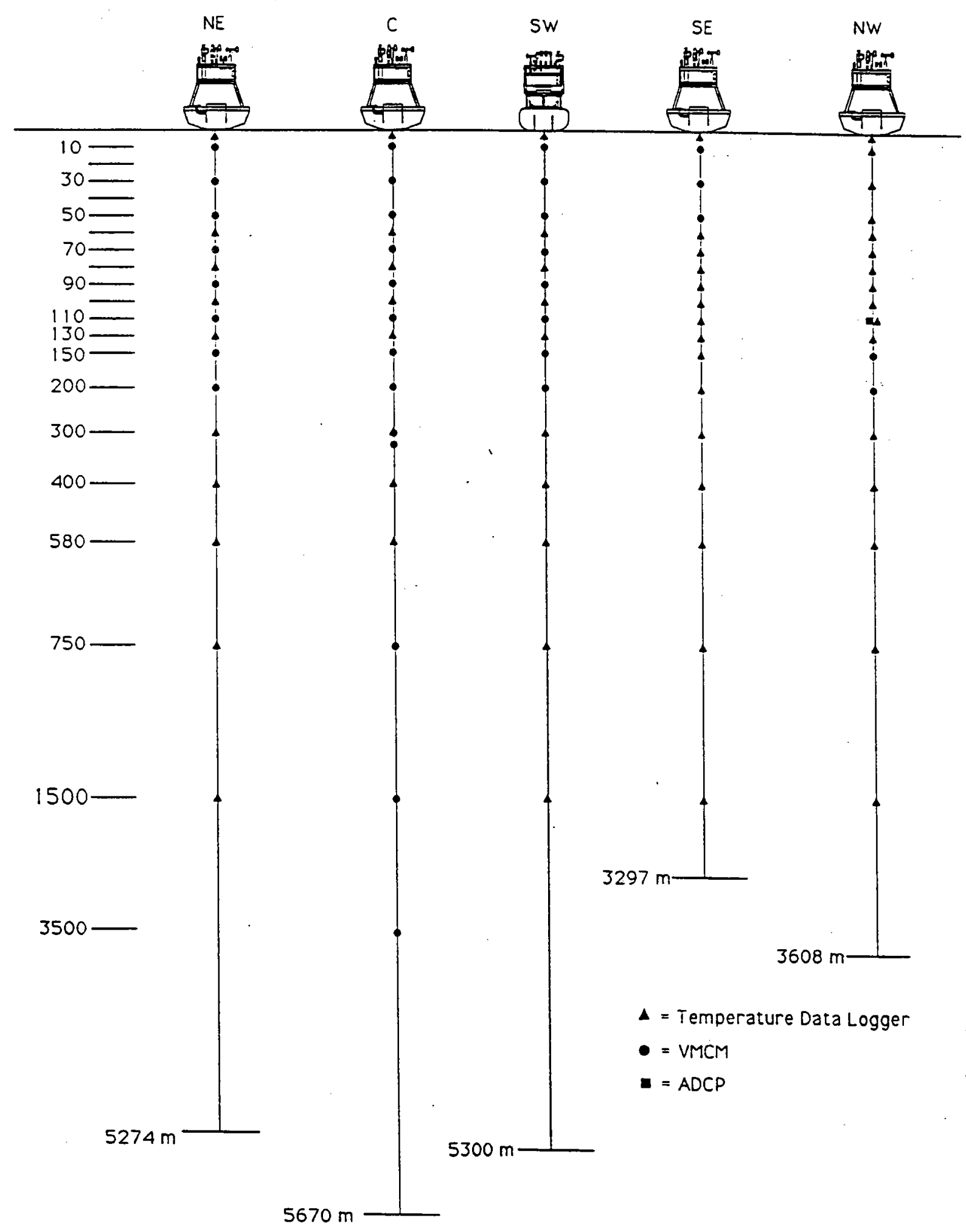




\section{B. Instrumentation}

A total of 102 recording instruments were deployed on the five Subduction 2 moorings. There were 9 meteorological packages, 34 current meters, 58 temperature data loggers, and one Acoustic Doppler Current Profiler. The specific instrumentation deployed and recovered from the first Subduction setting is shown in table 3. The instrumentation on the second setting is shown in table 4.

\section{Meteorological Instrumentation}

Each discus buoy was outfitted with two separate meteorological instruments. One system was a Vector Averaging Wind Recorder (VAWR) which recorded measurements of wind speed and direction, air temperature, relative humidity, barometric pressure, sea surface temperature, shortwave radiation, and longwave radiation. Additional information about the VAWR can be found in Trask et al, (1989). The other meteorological package was an IMET system which made measurements of the same variables as the VAWR plus precipitation. The IMET systems on the second Subduction deployment did not have longwave radiation sensors. Both the VAWR and IMET systems individually recorded all data internally as well as telemetered their data via Argos. The VAWR stored its data on cassette tape every 15 minutes and the IMET system recorded on optical disk every minute.

For both the discus and toroid buoys the VAWR sensors (except sea temperature) and electronics with battery pack were attached to the tower top. The sea surface temperature sensors for both the VAWR and IMET systems were attached to the buoy bridle approximately 1 meter below the surface. All other meteorological sensors were placed at the same heights on the tower tops as in Subduction 1 (see Trask and Brink, 1993). During the second Subduction setting the Southwest toroid did not have an IMET system. The IMET sensors on all the discus buoys were configured the same and mounted on the tower top. The IMET electronics and rechargeable batteries were housed in the discus buoy water tight instrument well.

Details regarding the IMET performance during the first setting can be found in Appendix 3.

Prior to deployment the air and sea temperature sensors as well as the relative humidity sensors were calibrated at WHOI. The calibrations of the barometric pressure sensors were checked and if found out of specification were returned to the manufacturer for recalibration. The shortwave and longwave radiation sensors were calibrated by the manufacturer. The wind direction sensor readings were compared with a known bearing to a fixed target. Details of the direction comparison tests can be found in Appendix 4.

\section{Current Meters}

A total of 34 Vector Measuring Current Meters (VMCM) provided by both WHOI and SIO were deployed on the five Subduction 2 surface moorings. The 22 WHOI VMCMs were a modified version of the EG\&G Sea Link instrument whereas the 12 SIO VMCMs were built by Scripps personnel. The sampling interval of the WHOI VMCMs was 7.5 minutes, and for the SIO VMCMs it was 15 minutes.

The WHOI VMCMs incorporated several changes to the standard EG\&G Sea Link product. These included different propeller bearings, a different plastic for the propeller blades, an external temperature pod for faster temperature response, and a redesigned the instrument cage. The cage redesign and external temperature pod is described in Trask et al, (1989) as is some historical information on propeller bearings and blade materials. 
Table 3.

Subduction 1 Instrumentation

\begin{tabular}{|c|c|c|c|c|c|}
\hline Depth & $\mathrm{NE}$ & C & SW & SE & NW \\
\hline $\begin{array}{l}\text { VAWR } \\
\text { IMET }\end{array}$ & V-704WR & V-722WR & V-720WR & V-721WR & V-121WR \\
\hline 10 & VM-041 & VM-035 & SVM-04 & SVM-12 & S-3285 \\
\hline 20 & TEST STING1 & & & TEST STING2 & \\
\hline 30 & VM-021 & VM-033 & SVM-07 & VM-007 & S-3315 \\
\hline 40 & TEST STING3 & & & & \\
\hline 50 & VM-039 & VM-024 & SVM-06 & SVM-16 & S-3294 \\
\hline 60 & W-3274 & W-3309 & S-3314 & W-3297 & W-3262 \\
\hline 70 & VM-032 & VM-012 & SVM-22 & S-3282 & S-3313 \\
\hline 80 & W-3265 & W-3308 & W-3279 & S-3270 & S-3260 \\
\hline 90 & VM-022 & VM-038 & SVM-02 & S-3298 & $S-3261$ \\
\hline 100 & W-3288 & W-3296 & W-3303 & S-3284 & W-3258 \\
\hline 110 & VM-030 & VM-009 & SVM-05 & S-2425 & $\begin{array}{l}\text { ADCP } \\
\text { S-3277 }\end{array}$ \\
\hline 130 & W-3269 & $W-3280$ & S-2427 & S-2432 & S-2434 \\
\hline 150 & VM-028 & VM-037 & SVM-20 & $S-2418$ & SVM-11 \\
\hline 200 & VM-018 & VM-016 & SVM-13 & $S-2424$ & SVM-10 \\
\hline 206 & COND & & & & \\
\hline 300 & W-3300 & W-3289 & S-2435 & S-2433 & $S-2421$ \\
\hline 400 & W-3305 & W-3283 & S-2437 & S-2422 & S-2431 \\
\hline 580 & W-3268 & W-3271 & W-3341 & W-3290 & W-3272 \\
\hline 750 & W-3286 & VM-015 & $S-2436$ & $S-2426$ & $S-2420$ \\
\hline $\begin{array}{l}1500 \\
3490 \\
3500\end{array}$ & W-3293 & $\begin{array}{l}\text { VM-034 } \\
\text { TENS } 1029 \\
\text { VM-011 }\end{array}$ & W-3287 & W-3259 & W-3273 \\
\hline & $\begin{array}{l}\mathrm{W} \#=\text { WHOI B } \\
S-\#=\text { SIO Branc } \\
\text { VM\# = WHOI } \\
\text { SVM-\#= SIO V }\end{array}$ & $\begin{array}{l}\text { ancker Tempera } \\
\text { er Temperature } \\
\text { Vector Measuri } \\
\text { ector Measuring }\end{array}$ & $\begin{array}{l}\text { e Recorder } \\
\text { corder } \\
\text { Current Meter } \\
\text { urrent Meter }\end{array}$ & & \\
\hline
\end{tabular}


Table 4.

Subduction 2 Instrumentation

\begin{tabular}{|c|c|c|c|c|c|}
\hline Depth & NE & C & sw & SE & NW \\
\hline $\begin{array}{l}\text { VAWR } \\
\text { IMET }\end{array}$ & V-380WR & V-712WR & V-713WR & V-707WR & V-717WR \\
\hline 1 & W-3507 & W-3506 & W-3665 & W-3704 & W-3508 \\
\hline 10 & VM-034 & VM-002 & SVM-01 & SVM-03 & S-3709 \\
\hline 30 & VM-027 & VM-023 & SVM-16 & VM-010 & W-3274 \\
\hline 50 & VM-036 & VM-020 & SVM-08 & SVM-17 & W-3288 \\
\hline 60 & W-2539 & W-2541 & S-3285 & W-3279 & W-3296 \\
\hline 70 & VM-014 & VM-013 & SVM-15 & S-3707 & W-3309 \\
\hline 80 & W-2542 & W-2534 & $W-3263$ & S-3261 & W-3269 \\
\hline 90 & VM-045 & VM-019 & SVM-14 & S-3706 & W-2536 \\
\hline 100 & $W-3280$ & W-2537 & W-3291 & $S-3714$ & $W-2540$ \\
\hline 110 & VM-035 & VM-008 & SVM-12 & S-3710 & $\begin{array}{l}\text { ADCP-195 } \\
\text { W-2535 }\end{array}$ \\
\hline 130 & W-3265 & W-2538 & S-3310 & S-3294 & S-3313 \\
\hline 150 & VM-009 & VM-026 & SVM-11 & S-3715 & SVM-09 \\
\hline 200 & VM-011 & VM-025 & SVM-18 & S-3708 & SVM-21 \\
\hline 300 & S-3260 & VM-017 & $S-3713$ & S-3712 & S-3276 \\
\hline 310 & & VM-031 & & & \\
\hline 400 & S-3711 & W-2533 & $S-2430$ & $S-2423$ & S-3277 \\
\hline 580 & S-3298 & W-3262 & W-3299 & W-3303 & S-3316 \\
\hline 750 & $S-2426$ & VM-029 & S-2429 & S-2434 & S-3282 \\
\hline 1500 & S-2427 & VM-001 & W-3258 & W-3341 & S-3284 \\
\hline \multirow[t]{2}{*}{3500} & & VM-003 & & & \\
\hline & \multicolumn{5}{|c|}{$\begin{array}{l}\text { W\# = WHOI Brancker Temperature Recorder } \\
\text { S-\#= SIO Brancker Temperature Recorder } \\
\text { VM-\# = WHOI Vector Measuring Current Meter } \\
\text { SVM-\#= SIO Vector Measuring Current Meter }\end{array}$} \\
\hline
\end{tabular}


For the Subduction experiment the WHOI VMCMs in the upper 100 meters were outfitted with cages that had $3 / 4$ " cage rods. The deeper instruments had cages with $1 / 2$ " cage rods. All cages had a single cross brace to support the sting between the two sets of propellers.

An alternative propeller bearing chosen for use in the Subduction experiment was an all silicon nitride ball bearing ( $\mathrm{SiNi}$ balls and races with a Duroid ball retainer) available from Miniature Precision Bearing (MPB), of Keene, New Hampshire, as part number J0001-809. This was selected over the typical stainless steel bearing based on previous test results, actual deployments and the fact that the eight month Subduction deployment would be $30 \%$ longer than most previous deployments.

The same type of VMCM propellers used in the first setting of the Subduction experiment were used again for the second setting. They were made of an unpigmented Delrin $100 \mathrm{ST}$ which is impact modified. See Trask and Brink (1993) for more details about the bearing and blade materials.

The Subduction 1 VMCMs that were recovered during Oc-250 were in excellent condition with respect to propeller bearings and blades. None of the propellers had broken blades and the silicon nitride bearings were like new. They were in such good condition after the first 8 month deployment that two of the four instruments (VM009 and VM011) that had to be turned around at sea and redeployed used their original stings that had previously been in the water for eight months during Subduction 1. The other two instruments (VM034 and VM035) that were turned around at sea had new stings installed.

The data tapes from seven WHOI VMCMs recovered from the first setting of the Central and Northeast moorings were impossible to read with the equipment aboard ship. The problem was related to a bad batch of certified data cassettes. The data tapes that could not be read had the same code printed on the cassette whereas the readable data tapes had different codes. Five of the seven instruments affected by the bad cassette tapes were on the Central Subduction 1 mooring. They were VM033 at 30 meters, VM038 at 90 meters, VM037 at 150 meters, VM016 at 200 meters and VM015 at 750 meters. The Northeast mooring had two instruments with bad cassettes; VM032 at 70 meters and VM030 at 110 meters. The details of this problem are described in the cruise chronology by mooring.

\section{Temperature Loggers}

A total of 58 temperature data loggers manufactured by Richard Brancker Research Ltd. were provided by both WHOI and SIO for the five Subduction moorings. The locations of the loggers are shown in figure 4 and table 4 . The loggers provided by WHOI were attached to the mooring line using a hinge type clamp that was tightened around the wire. The SIO clamping arrangement consisted of two 2 piece monel blocks which had been machined to accept the mooring wire. The two pieces were clamped around the wire with $.25^{\prime \prime}$ hardware.

Several different models were deployed. The SIO 2000 series instruments sampled at 30 minute intervals. The WHOI 2000 series instruments which were modified for extra memory sampled at 15 minutes, and both the SIO and WHOI 3000 series instruments sampled at 15 minutes. The SIO 2000 series instruments had SIO fabricated pressure cases and endcaps.

A total of 15 temperature loggers recovered during Oc-250 leaked a small quantity of water, and the data could not be read. In response to this problem while at sea the instruments that were deployed for the second setting had a vacuum drawn during assembly to better seat the O-rings. This procedure was adopted from SIO whose nearly identical temperature loggers did not display the problem as severely. In addition, the endcaps were tightened considerably more than previously deployed units using a large adjustable wrench. The performance of the temperature 
loggers recovered from the first setting is described in the Section 3 of this report by mooring on which they were deployed.

\section{ALACE Floats}

A total of 11 SIO Autonomous LAgrangian Circulation Explorers were deployed during Oc-250. Details of those deployments can be found in Appendix 5 of this report.

\section{Underway Measurements}

\section{Expendable Bathythermographs (XBT)}

Three hundred XBTs were deployed during Oc-250. The T-7 probes were purchased from Spartan of Canada. XBT data was logged on a NEC APC IV which had a Spartan data acquisition microprocessor card installed. The digital data was simultaneously logged in memory and plotted on the screen. In all there were very few probes that failed to produce reasonable data.

R/V Oceanus transited from Woods Hole to the drifting Southwest buoy before reaching the Subduction site, during this time XBTs were dropped every four hours. Following the deployment of the Southwest mooring XBTs were made hourly. The details of the XBTs can be found in Appendix 6.

\section{Meteorological Observations}

From the time the ship left Woods Hole meteorological data from a shipboard IMET system mounted on the bow mast were recorded on optical disk. The IMET sensors included wind speed and direction, seawater temperature (made in the seawater intake of the main engine), barometric pressure, air temperature, relative humidity, precipitation and shortwave radiation. Minute data was logged to a dedicated PC with optical disk. The data was also displayed on the PC monitor.

Manual meteorological observations were also taken hourly on the hour. The manual observations consisted of recording the time, GPS position, ship's speed, ship's heading, wind speed and wind direction from the bridge readout, barometric pressure from the bridge, wet and dry bulb temperatures from a Bendix psychrometer, sea surface temperature from a bucket thermometer, cloud type, and visual cloud cover estimates. Relative humidity was computed using a conversion program on the MacIntosh computer. In addition the corresponding ship mounted IMET data displayed on the PC monitor were also recorded by hand. Information on the shipboard IMET system and a comparison of the data collected with the manual observations is .presented in Appendix 7.

\section{Acoustic Doppler Current Profiler}

Velocity and temperature data were collected by an Acoustic Doppler Current Profiler mounted in the hull. See Appendix 8 for a summary of the data files collected. 


\section{Section 3: Cruise Chronology}

Oceanus cruise number 250 departed Woods Hole on Saturday, 25 January 1992 at 1130 UTC. The purpose of the cruise was to recover and redeploy an array of five surface moorings deployed in June/July 1991 as part of the ONR funded ASTEX and Subduction Experiment. This was the second of four scheduled mooring cruises planned for this experiment. Details of the cruise are described below by mooring. For an abridged version of the cruise chronology see Appendix 9.

\section{Southwest Mooring}

The Oceanus arrived at the drifting toroid buoy at 0515 UTC on Sunday, 2 February 1992 at position $15^{\circ} 13.09^{\prime} \mathrm{N}, 44^{\circ} 47.48 \mathrm{~W}$. The buoy's marine lantern was first sited at a distance of approximately 5 miles. After a brief opportunity for fishing the buoy and parted mooring were brought aboard. Figure 5 is a schematic of the mooring as it was deployed in June 1991. An XBT $(\# 44)$ was taken while along side the buoy prior to recovery. A total of 6 SIO Vector Measuring Current Meters (VMCMs at $10 \mathrm{~m}, 30 \mathrm{~m}, 50 \mathrm{~m}, 70 \mathrm{~m}, 90 \mathrm{~m}$, and $110 \mathrm{~m}$ ), 2 WHOI Brancker temperature recorders $(80 \mathrm{~m}, 100 \mathrm{~m})$ and 1 SIO Brancker temperature recorder $(60 \mathrm{~m})$ were recovered. The last item to be recovered was the 110 meter current meter which did not have a shackle in the bottom bale. The top bale of the 110 meter VMCM had a shackle and bolt but had lost its nut and cotter pin. The titanium pin in the lower bale of the $110 \mathrm{~m} \mathrm{VMCM}$ was extremely worn. In addition to the load cage wear the VMCM sting (orthogonal propeller assembly) was missing from the instrument which caused the instrument to flood. Both WHOI Brancker temperature recorders (\#3279 at $80 \mathrm{~m}$ and $\# 3303$ at $100 \mathrm{~m}$ ) as well as the SIO Brancker ( $\# 3314$ at $60 \mathrm{~m}$ ) were opened and the data read without any problem. The VAWR meteorological package recorded data the entire time the buoy was on station but failed on 30 November 1991.

With the upper part of the mooring aboard the Oceanus got underway at 0730 UTC for the original Southwest mooring site at $18^{\circ} 00.03^{\prime} \mathrm{N}, 33^{\circ} 59.96^{\prime} \mathrm{W}$. The ship arrived at the site on 4 February 1992 at 1152 UTC. Upon arriving at the site the location of the anchor was checked by ranging on the acoustic release from approximately 2 miles away. The range obtained confirmed the original anchor position obtained during the setting cruise in June/July 91. The ship was then positioned one-half mile down wind of the anchor position and the release was fired at 1235 UTC. Confirmation of release was not detected right away. A continual decrease in slant ranges indicated that the release was rising. Slant ranges to the release were monitored the entire time the mooring was coming to the surface. The ship continued to drift away from the site and had to be repositioned to the location where the release was fired several times. A set of 4 glass balls was sited at 1332 UTC. One by one the clusters of 4 balls were spotted strung out in line with the wind direction. All but two clusters were sited. The ship then cautiously proceeded parallel to the mooring until the large bottom cluster of 12 balls was spotted. Recovery of the bottom of the mooring was initiated at 1430 UTC. By 1843 UTC the entire parted mooring was on board. The uppermost part of the mooring was a cluster of 3 glass balls (one of the original four was missing and those remaining had cracked hardhat flanges), a shackle with master link and the top shackle with no bolt in place. The top shackle was originally attached to the bottom of the $110 \mathrm{~m}$ VMCM that was recovered below the drifting buoy. The entire mooring was therefore recovered.

The lower part of the mooring contained 4 SIO Brancker Temperature Recorders (at $130 \mathrm{~m}$, $300 \mathrm{~m}, 400 \mathrm{~m}, 750 \mathrm{~m}), 2$ SIO VMCMs (at $150 \mathrm{~m}$ and $200 \mathrm{~m}$ ) and 2 WHOI Brancker Temperature Loggers (at $580 \mathrm{~m}$ and $1500 \mathrm{~m}$ ). WHOI temperature logger $\$ 3287$ at $1500 \mathrm{~m}$ and SIO temperature logger \#2436 at $750 \mathrm{~m}$ had several drops of water inside when the instruments were opened. The water appeared to have just entered the pressure case sometime during recovery since there was no indication of corrosion. The data however could not be read from these instruments. This 


\section{Figure 5. Subduction 1 Southwest Mooring Schematic}

\section{SOUTHWEST SUBDUCTION MOORING}

WHOI MOORING NO. 916

\begin{tabular}{|c|c|}
\hline \multicolumn{2}{|c|}{$\begin{array}{c}\text { Temperature Poos } \\
\text { No }\end{array}$} \\
\hline 1 & Depth $(\mathrm{m})$ \\
\hline 2 & 80 \\
\hline 3 & 100 \\
\hline 4 & 130 \\
\hline 5 & 300 \\
\hline 6 & 400 \\
\hline 7 & 580 \\
\hline 8 & 750 \\
\hline 9 & 1500 \\
\hline
\end{tabular}

Water Depth $=5307 \mathrm{~m}$

$580 \mathrm{~m}$
SIO Toroid Buoy

with 1 VAWR with Argos

Telemetry and I IMET System

Swive

$6.3 \mathrm{~m} 3 / 4^{\prime \prime}$ Chain

$17.2 \mathrm{~m} 3 / 8^{-}$wire

$17.2 \mathrm{~m} \mathrm{3/8"} \mathrm{Wire}$

$17.2 \mathrm{~m} \mathrm{3/8"wire}$

$17.2 \mathrm{~m} \mathrm{3/8"wire}$

$17.2 \mathrm{~m} \mathrm{3/8"Wire}$

(4) 17 " glass balls

$37.2 \mathrm{~m} \mathrm{3/8"Wire}$

$47.3 \mathrm{~m} 3 / 8$ " wire

(4) 17" glass dalls

$101 \mathrm{~m} 3 / 8^{\circ}$ Wire

$250 \mathrm{ml} \mathrm{3/8"} \mathrm{wire}$

(4) 17" glass balls

8

Temperature Poo

Temperalure Poa

$250 \mathrm{~m} \mathrm{3/8"} \mathrm{wire}$

(4) 17" glass balls

$250 \mathrm{M} \mathrm{3/8"} \mathrm{Wire}$

(4) 17" glass Dalls

$250 \mathrm{~m} \mathrm{3/8"} \mathrm{wire}$

(4) 17 glass dails

$250 \mathrm{mi} 3 / 8^{\circ}$ wire

(4) 17 qlass balls

$250 \mathrm{~m} 3 / 8$ " wire

(4) 17 qlass balls

$200 \mathrm{mi} 3 / 8$ " wire

(6) $500 \mathrm{~m}$ shols of $3 / 4$ " Nylon

$200 \mathrm{~m} 3 / 4$ " Nylon

$68 \mathrm{~m} 3 / 4^{\circ}$ Nylon

Swivel

(12) 1? glass balls

$20 \mathrm{~m} 3 / 8 "$ wire

$4 \mathrm{~m} \mathrm{3/4"} \mathrm{Cnain}$

$30 \mathrm{~m} \mathrm{9/8"} \mathrm{Nylon}$

$30 \mathrm{~m} 3 / 4^{\prime \prime}$ Chain

$30 \mathrm{~m} \mathrm{3/4"} \mathrm{Chain}$

6000 pouna Anchor

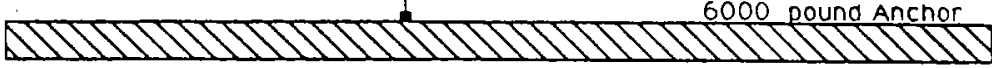

22 October 91 
particular SIO Brancker that leaked had an SIO fabricated pressure case and endcaps. Inspection of the pressure case face seals revealed markings in the anodizing. The same pressure case design as that used by Brancker was also used to fabricate the SIO pressure case. All SIO purge plugs were not the standard Brancker issue. SIO replaced the Brancker purge plug with one fabricated of Ertalyte (P.E.T.).

With the mooring aboard attention was turned to preparing for redeployment. The deck was cleared and off-spooling the wire on the winch was begun. Simultaneously three acoustic releases were wire tested using the CTD winch. Two SIO releases and one WHOI release were tested to a depth of 1000 meters. These operations were followed by rewinding the wire and nylon for the next mooring. The mooring schematic for the second setting of the Southwest mooring is shown in figure 6. Due to space limitations on the TSE winch drum only the upper 3200 meters of wire and nylon were wound on the winch. While the winding was taking place the ship was positioned 7 miles to the south southwest. This was downwind of the target and slightly south to compensate for a small northerly current.

The deployment of the upper instrumentation (10m and $30 \mathrm{~m} \mathrm{VMCMs)} \mathrm{and} \mathrm{buoy} \mathrm{(in} \mathrm{that}$ order) went quite smoothly. With the buoy in the water the ship initially had just enough way on to maintain steerage. As more instrumentation and wire were deployed the speed through the water was increased to $.5 \mathrm{knot}$ and then to $1.0 \mathrm{knot}$. Mid-way through the deployment the mooring was towed while 1800 meters of nylon and 500 meters of polypropylene were wound onto the winch. During towing the ship's speed was decreased to $.7 \mathrm{knot}$ due to an increase in the tension in the nylon. This speed was maintained as the remainder of the mooring was deployed.

With the reduction in the ship's speed, progress over the bottom was slower than expected. The mooring had been cut for deployment in water similar to the original water depth of 5307 meters. The plan was to continue to tow until the water depth was within 40 meters of the planned depth. Unfortunately during our approach the water was several hundred meters shallower than what was needed. Towing had to continue at a slow pace until the design depth was obtained. As the ship approached the original target the water depth increased for a sufficient distance to permit the deployment of the mooring. The anchor was deployed at 1318 UTC on 5 February 1992.

Following the anchor deployment the ship was repositioned to watch the toroid buoy ride through the water as the anchor went to the bottom. The toroid behaved considerably different during this deployment than it had in previous deployments in June/July 91 . In comparison with the Subduction 1 toroid deployments the speed through the water was much less $(.7 \mathrm{kt})$, the toroid was not heeled over as much, and it did not submerge.

Two hours of intense meteorological observations were made as the buoy settled into position. Meteorological observations were obtained by hand held and bridge mounted sensors and logged with the IMET data every 15 minutes. At the same time the VAWR Argos transmissions were received directly from the buoy via the Telonics receiver aboard ship. These data were compared at the end of the two hour period. All observations compared well. These observations are used as a final check of instrument performance before leaving the site.

An acoustic release survey followed. Three positions were selected approximately 2-3 miles away from the suspected anchor location. From each position a horizontal range to the release was obtained. Figure 7 shows the results of the survey which located the anchor of the Southwest mooring (WHOI Mooring number 924) at $17^{\circ} 59.93 ' \mathrm{~N}$ and $34^{\circ} 00.65^{\prime} \mathrm{W}$. Following the survey the acoustic release was disabled and confirmation obtained. The anchor fall back for this mooring was 238 meters or $4.5 \%$ of the water depth. The water depth at the site was 5300 meters corrected. The total depth correction was +50 meters $(+3$ transducer depth +47 Matthew's correction) and the sound speed used was $1514 \mathrm{~m} / \mathrm{sec}$. 
Figure 6. Subduction 2 Southwest Mooring Schematic

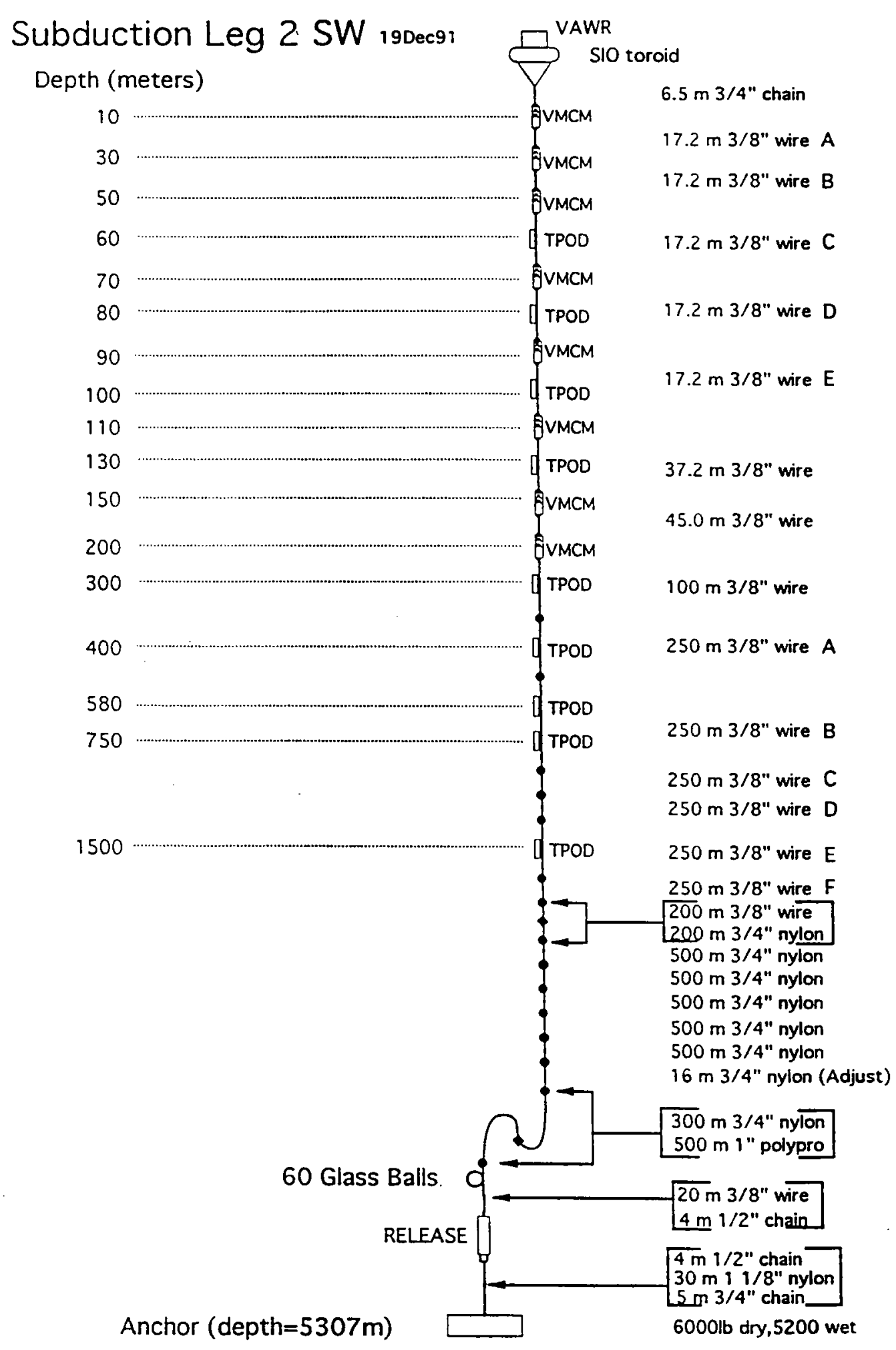


Figure 7. Subduction 2 Southwest Acoustic Release Survey

Subduction 2

Southwest Mooring

Mooring Number 924

Acoustic Release Survey

5 February 1992

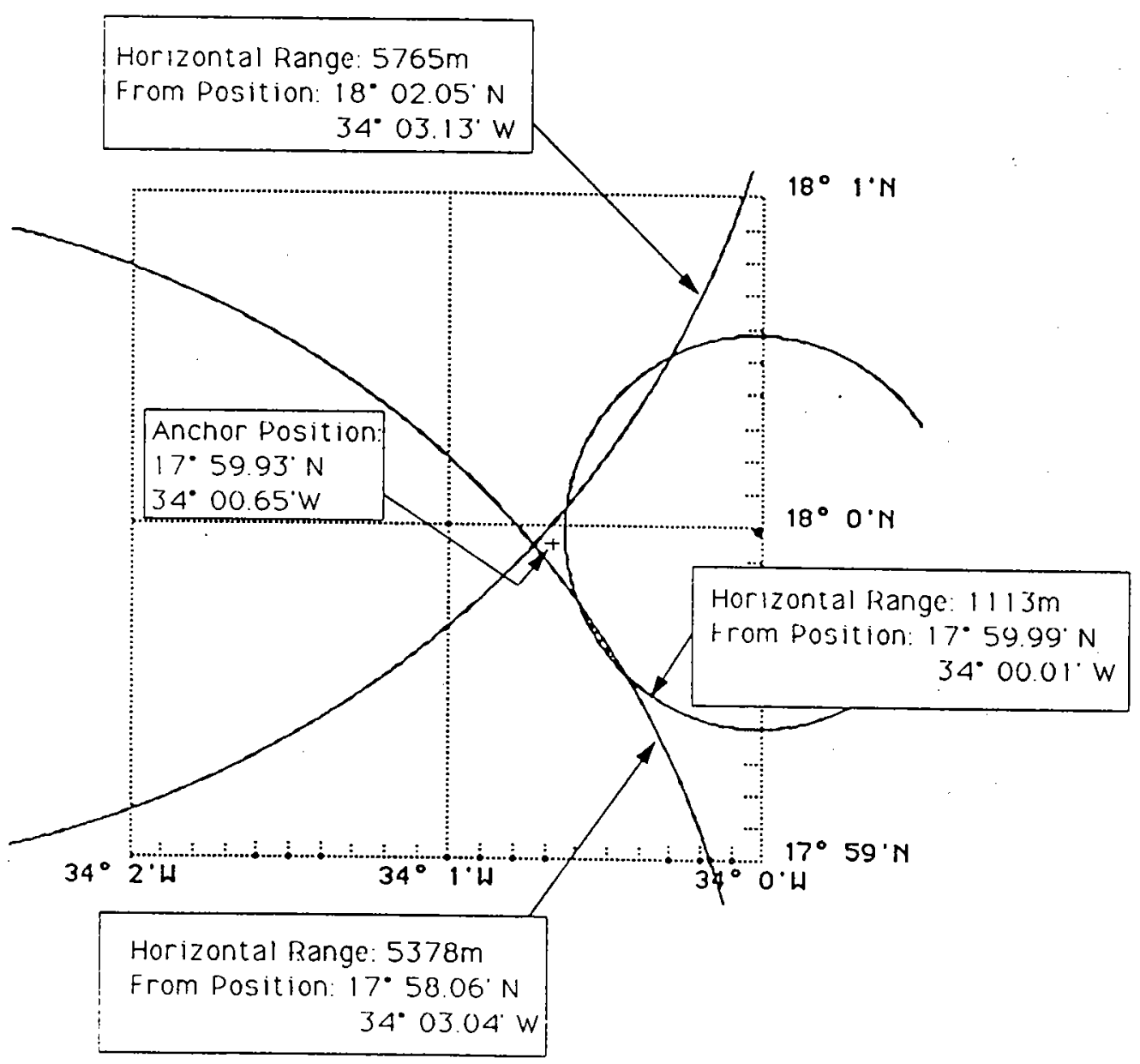


The ship immediately got underway for the Southeast mooring location $\left(18^{\circ} \mathrm{N}\right.$ and $\left.22^{\circ} \mathrm{W}\right)$ at 1750 UTC 5 February 1992. The meteorological watch was resumed and hourly XBTs were started at 1900 UTC.

\section{Southeast Mooring}

Oceanus arrived at the Southeast site at 0507 UTC on 8 February 1992. This mooring shown in figure 8 was originally set on 29 June 1991 and had parted on 10 October 1991. Since all that remained were the subsurface components with no recovery aids such as a flashing light we waited until daylight to release it.

While we waited a three point acoustic release survey was conducted. The results of that survey showed that the release was within 150 meters of the position determined when the mooring was set. Also during the wait for daylight time was spent determining the set and drift of the ship which would aid in the deployment.

The acoustic release was fired at 0853 UTC 8 February 1992 and the mooring was sighted at 0936 . Recovery was initiated at the release end of the mooring and proceeded very smoothly. The entire mooring was on board by 1155 UTC. The last component to be recovered was a cluster of three glass balls ( one was missing) the top of which had no shackle or master link. These balls were originally just below the $50 \mathrm{~m}$ VMCM which had been recovered with the top of the mooring in October 1991.

All three WHOI Brancker temperature loggers recovered from this mooring (\#3297 at $60 \mathrm{~m}$, $\# 3290$ at $580 \mathrm{~m}$, and $\# 3259$ at $1500 \mathrm{~m}$ ) appeared to have taken on small drops of water during recovery and the data could not be read from the instruments. The failure mode appeared to be the same as that seen at the previous mooring. The SIO Brancker temperature loggers did not leak and their data could be read from memory. The SIO Branckers were a combination of loggers with SIO fabricated pressure cases and Brancker fabricated cases. Both types worked equally well. The SIO instruments with the 2000 series serial numbers had the SIO fabricated pressure cases.

The deck was cleared, glass balls transferred, and the discus buoy was moved into deployment position. A test lowering of three acoustic releases followed along with the off spooling of the recovered mooring and the rewinding of the new mooring. The SIO mooring schematic for the second setting of the Southeast mooring is shown in figure 9 . While the wire was being wound one shot was found to have a serious tendency to twist and kink. It was unclear whether the problem was in the wire or in the manner in which it was wound onto the winch. The winding setup was from the tensioning payout cart through a 4" block and then onto the winch. The angle between the wire from the cart and the wire going onto the winch was less than $45^{\circ}$. This same winding arrangement had been used for the Southwest mooring without any noticeable damaging effects to the wire. The bad shot of Southeast wire was replaced and two blocks were used to route the wire onto the winch. No further problems were seen with the remaining shots of wire. All the wire shots and the wire to nylon shot were wound on the winch. The remaining part of the mooring was wound while the mooring was in tow.

Deployment of the Southeast mooring began at 2224 UTC on 8 February 1992. The ship was positioned 4 miles to the southwest of the target. This starting position was downwind and slightly to the north to compensate for a southerly drift experienced earlier. The deployment went along quite smoothly. Since the bottom was very flat and exact positioning was not important the deployment proceeded right through to anchor drop without any towing except that which was needed to wind the remainder of the mooring onto the winch. The anchor was deployed at 0244 UTC on 9 February 1992. 


\section{Figure 8. Subduction 1 Southeast Mooring Schematic}

SOUTHEAST SUBDL
MOORING
WHOI MOORING NO. 917
\begin{tabular}{|l|l|}
\hline TemDerature Poos \\
No & Depen (m) \\
\hline 1 & 60 \\
\hline 2 & 70 \\
\hline 3 & 80 \\
\hline 4 & 90 \\
\hline 5 & 100 \\
\hline 6 & 110 \\
\hline 7 & 130 \\
\hline 8 & 150 \\
\hline 9 & 200 \\
\hline 10 & 300 \\
\hline 11 & 400 \\
\hline 12 & 580 \\
\hline 13 & 750 \\
\hline 14 & 1500 \\
\hline
\end{tabular}

\section{UCTION}
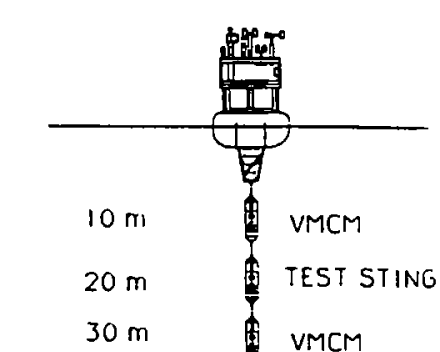

SIO Toroid BuOY

with I VAWR with Argos

Telemetry and I IMET System

Wivel

$6.3 \mathrm{~m} 3 / 4 "$ cnain

$7.3 \mathrm{~m} \mathrm{3/8" \text {WIre }}$

$7.3 \mathrm{~m} \mathrm{3/8"Wire}$

$17.2 \mathrm{~m} \mathrm{3/8*}$ Wire

(A) 17" glass dalls

$60 \mathrm{~m}$

VMCM

Partec $\longrightarrow$

Temperature Pod

i emperalure Pod

Temperature Pod

Temperalure Pod

Temperalure Pod

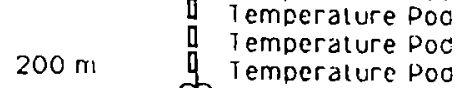

$\$$

$300 \mathrm{~m}$ Temperalure poo

$400 \mathrm{~m}$

$\$ 8$

Temperalure poo

$580 \mathrm{~m}$

I I emperalure Poo

$750 \mathrm{~m}$

7 emperature Poo

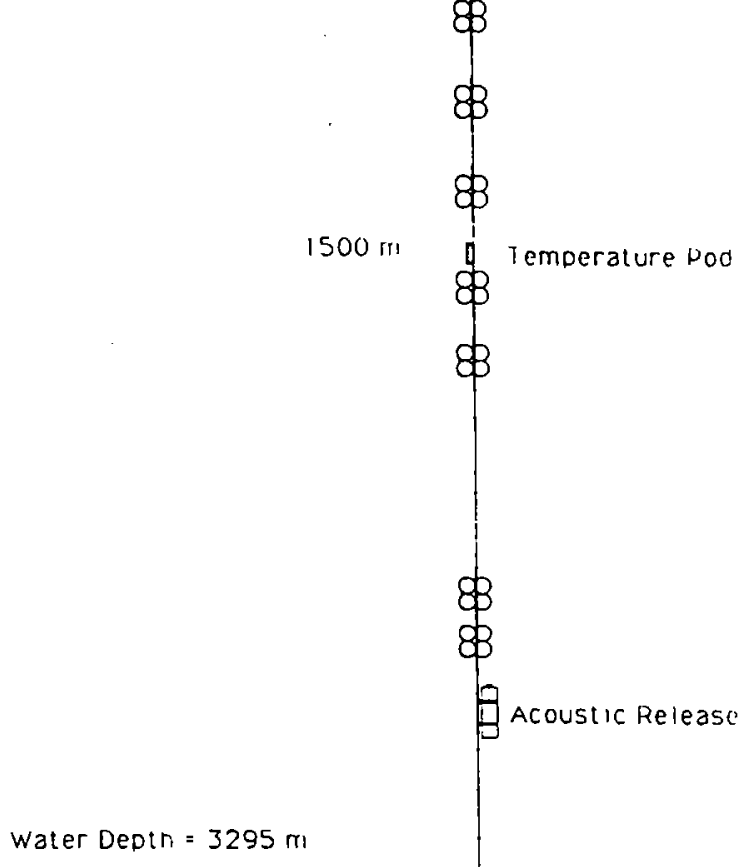

(A) $1 \%$ glass valls

$250 \mathrm{~m} \mathrm{3} / 8^{\circ}$ " wirc

(4) 1\%" olass balls

$250 \mathrm{~m} 3 / 8^{\circ} \mathrm{WIrc}$

(4) $17^{\prime \prime}$ glass balls $250 \mathrm{~m} \mathrm{3/8"} \mathrm{WIrc}$

(4) 17" glass balls $250 \mathrm{M} 3 / 8^{\circ}$ Wire

(4) 17" olass balls $250 \mathrm{mi} 3 / 8$ " wire

(4) 17" glass balls

$250 \mathrm{ml} 3 / 8 " \mathrm{w}$ "We

(a) $17 "$ glass balls

$250 \mathrm{~m} \mathrm{3/8"W}$ "Wr

$500 \mathrm{~m} 3 / 4 " \mathrm{Ny} / 0 n$

$500 \mathrm{~m} 3 / 4 "$ Nylon $200 \mathrm{~m} \mathrm{3/4"} \mathrm{Nylon}$

$20 \mathrm{mi} 3 / \mathrm{a}^{2} \mathrm{Nylon}$

Swivel

(4) $1 \%$ giass bal!s

(4) $17^{\prime \prime}$ alass Dalls

$20 \mathrm{~m} 3 / 8^{*}$ wire

$4 \mathrm{~m} 3 / 4^{\prime \prime}$ Chain

Swivel

$30 \mathrm{~m} 9 / 8^{-}$Nylon

$30 \mathrm{~m} \mathrm{3/4"} \mathrm{Chain}$

$30 \mathrm{~m} \mathrm{3/4" \text {Chain }}$

6000 pound Anchor

22 October 91 


\section{Figure 9. Subduction 2 Southeast Mooring Schematic}

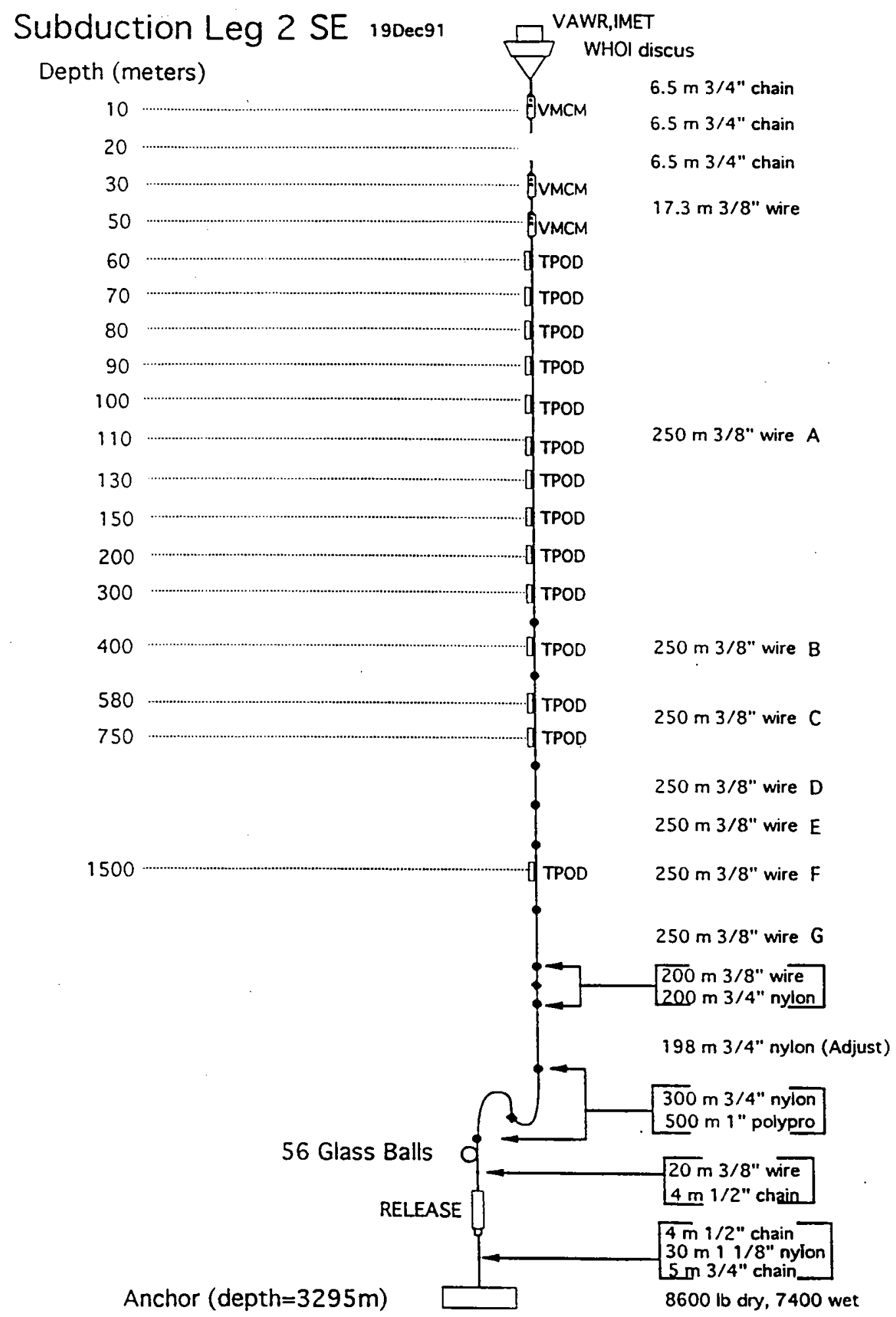


Following the deployment, four hours were spent taking meteorological observations every 15 minutes while standing by the surface buoy. An acoustic release survey was then conducted. The results of that survey are shown in figure 10. The anchor position for the Southeast mooring (WHOI Mooring number 925) was $17^{\circ} 59.72^{\prime} \mathrm{N}, 2^{\circ} 00.29^{\prime} \mathrm{W}$. The anchor fall back for this mooring was 311 meters or $9.4 \%$ of the water depth. The water depth is 3297 meters corrected (total correction $=+4$ meters) and the sound speed used was $1501.8 \mathrm{~m} / \mathrm{sec}$. At the conclusion of the release survey the ship got underway for the Central mooring site.

\section{Central Mooring}

The R/V Oceanus arrived at the Central mooring site at 1100 UTC on 11 February 1992.

Figure 11 is a schematic of the first setting of the Central mooring. At a distance of approximately 1.5 miles an acoustic range to the release was taken to ascertain whether the anchor was in the same position as when it was deployed. The range obtained confirmed the original anchor position. The ship then got into position to make an approach for recovery. With the buoy just off the bow of the ship the release commands were sent and confirmation of release received. The ship then moved in for recovery. The buoy appeared in good condition and came aboard without any damage.

Half way through the recovery the mooring was stopped off and towed in order to offspool the wire on the winch. The total recovery operation took 7 hours and 10 minutes. The bottom cluster of glass balls had a number of broken super-ribbed hardhats in the flange that attaches to the chain. There were, however, no broken glass balls.

There was a minimal amount of growth on the buoy which indicated that the antifouling paint worked well during the eight months the buoy was in the water. On some sections of the hull the paint had worn away and it was unclear whether the same application of paint would work for a much longer deployment. The same was noticed with the VMCMs that were recovered. All the VMCMs appeared in good condition. All propeller blades were intact, propellers were freely spinning and propeller bearings did not exhibit any noticeable wear. The Brancker temperature logger clamps were however difficult to remove from the wire. This was believed to be due to the dimensions specified for the delrin bushings. This problem was rectified by adjusting the bushing dimensions so as to increase clearances where needed.

The VAWR and IMET meteorological packages recorded full data records for the deployment of the Central mooring. Five VMCMs (at $10 \mathrm{~m}, 70 \mathrm{~m}, 110 \mathrm{~m}, 1500 \mathrm{~m}$, and $3500 \mathrm{~m}$ ) worked throughout the deployment, one VMCM recorded less than a full data tape $(50 \mathrm{~m})$ and five VMCMs (at $30 \mathrm{~m}, 90 \mathrm{~m}, 150 \mathrm{~m}, 200 \mathrm{~m}$ and $750 \mathrm{~m}$ ) had data tapes which were unreadable with the equipment on board ship. Close inspection of the five cassette data tapes that were unreadable indicated that they had the same manufacturers code printed on the cassette housing. The code was 2931-3823. The readable tapes had different codes. Numerous attempts at reading the cassette tapes were unsuccessful.

Three Brancker temperature recorders (at $60 \mathrm{~m}, 100 \mathrm{~m}$, and $130 \mathrm{~m}$ ) had full data records, one (at $80 \mathrm{~m}$ ) had a partial record, and three instruments (at $300 \mathrm{~m}, 400 \mathrm{~m}$, and $580 \mathrm{~m}$ ) flooded with a small quantity of water and could not be read.

Half of the glass balls and hardhats from this mooring were turned around with new chain and hardware. The other half were taken from the already refurbished glass balls that were brought from Woods Hole. The mooring was off-spooled and the new mooring components were wound onto the winch beginning with the wire to nylon shot. The buoy bridle and bridle mounted instruments were given a coat of anti-fouling paint. At the completion of the preparatory work a decision was made to rest for the remainder of the evening and begin the deployment after breakfast the following day. 
Figure 10. Subduction 2 Southeast Acoustic Release Survey
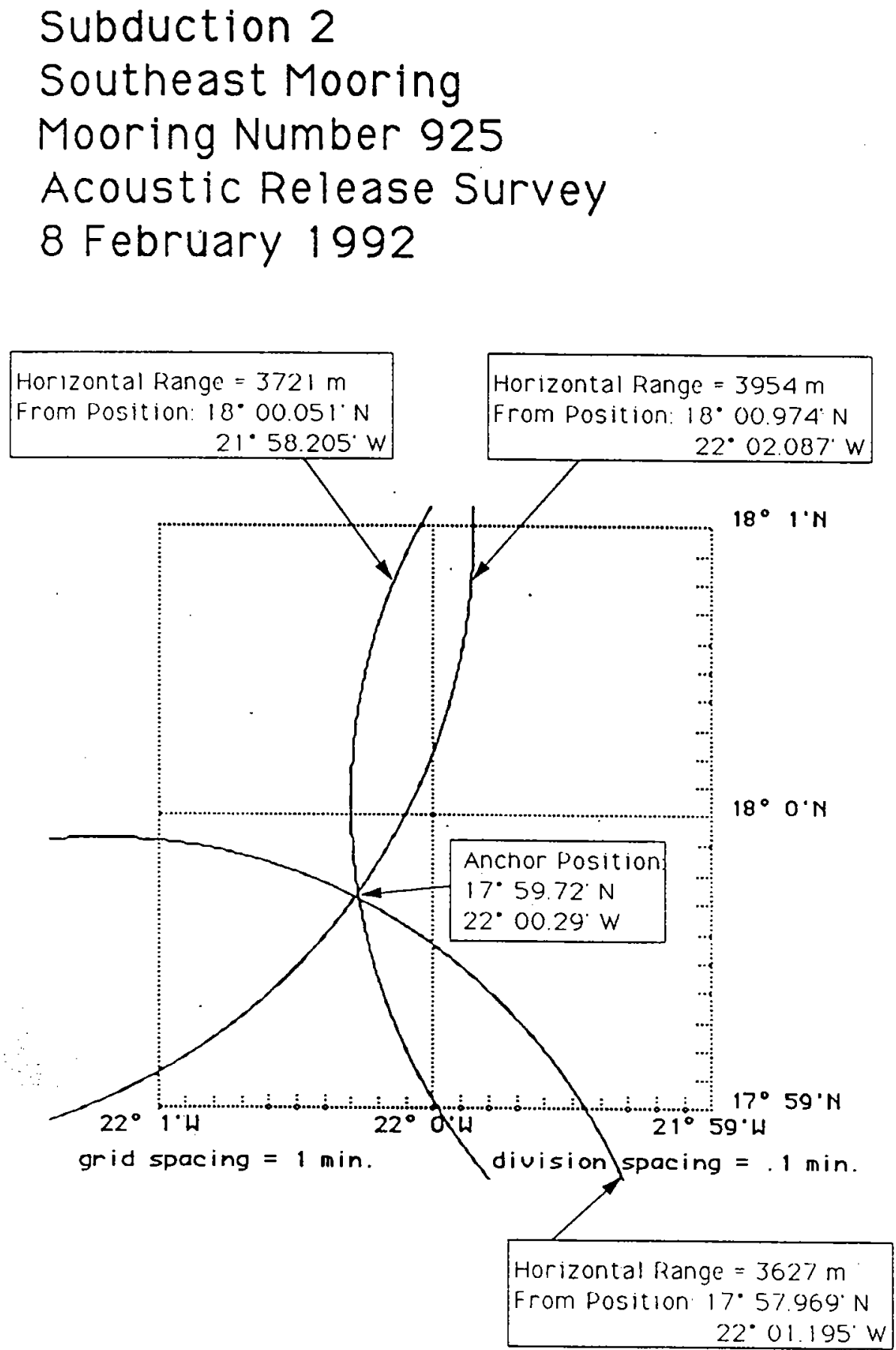
Figure 11. Subduction 1 Central Mooring Schematic

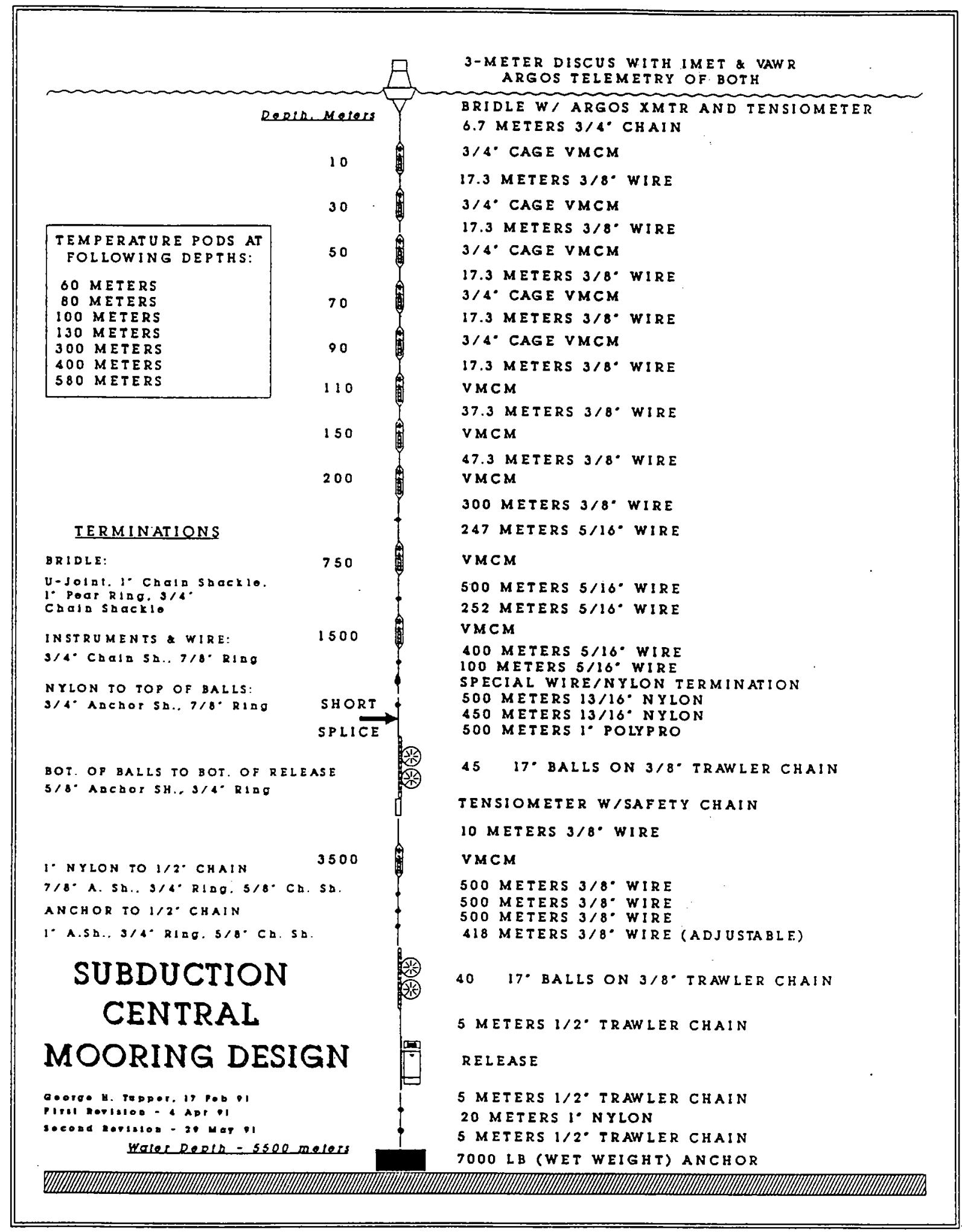


The deployment of the second setting of the Central mooring (figure 12) began at 1037 UTC on 12 February 1992. The ship was positioned 5 miles downwind (east-southeast of the site) and proceeded at an average speed of about $.6 \mathrm{knots}$ over the bottom. After the wire to nylon shot was deployed it was necessary to tow the mooring for about 2 hours while the remainder of the mooring was wound onto the winch. The last cluster of balls were deployed along with the release and the mooring was towed for about 30 minutes until the appropriate water depth was obtained. The anchor was deployed at 1915 UTC, 12 February 92.

Following the deployment an acoustic release survey was conducted. The results of that survey are shown in figure 13. The anchor position for the second setting of the Central mooring (WHOI Mooring number 926) was $25^{\circ} 31.95^{\prime} \mathrm{N}, 28^{\circ} 57.23^{\prime} \mathrm{W}$. The mooring anchor fell back $778 \mathrm{~m}$ or $13.7 \%$ of the water depth from its anchor drop position. The corrected water depth was 5670 (total correction $=+70$ meters) and the sound speed used was $1518 \mathrm{~m} / \mathrm{sec}$. The release used on the Central Mooring was a Model 323 which did not have the disable option.

The ship then returned to within .25 miles of the surface buoy. Meteorological observations were made every 15 minutes until 0100 UTC 13 February 92 at which time the Oceanus got underway for the Northeast mooring. Hourly meteorological observations were resumed and hourly XBTs were started at 0200 UTC.

\section{Northeast Mooring}

The ship arrived at the Northeast mooring at 2253 UTC on 14 February 92 . Figure 14 is a schematic of the first setting of the Northeast mooring. At a distance of approximately 1.5 miles an acoustic range to the release was made to ascertain whether the anchor was in the same position as when it was deployed. The range obtained confirmed the original anchor position. The ship then got into position to make an approach for recovery. With the buoy just off the bow of the ship the release commands were sent. The ship then moved in for recovery. The buoy was brought aboard without any problems.

There were considerably more goose neck barnacles on the underside of the Northeast buoy than was observed on the Central buoy and the VMCM at $10 \mathrm{~m}$ also had quite a few growing on it as well. The VMCMs at $10 \mathrm{~m}$ and $30 \mathrm{~m}$ and the test sting at $20 \mathrm{~m}$ had the majority of growth. The tension in the mooring line remained high throughout the recovery presumably due to the drag caused by the cluster of 61 glass balls at the bottom of the mooring. The bottom of the mooring with glass balls and the release was brought on board at 0541 UTC. Aside from two shredded glass ball hardhats that appear to have had glass balls that imploded at depth there were no other broken glass balls.

The IMET package produced a readable data record for the entire deployment. The VAWR however produced a short record having failed on 30 October 1991 . Two VMCMs (at $70 \mathrm{~m}$ and $110 \mathrm{~m}$ ) from the Northeast mooring had cassette data tapes with the same code as the five that were recovered from the Central mooring and could not be read with the equipment on board the ship. Two Brancker temperature recorders (at $80 \mathrm{~m}$ and $130 \mathrm{~m}$ ) had readable data, five instruments at $300 \mathrm{~m}, 400 \mathrm{~m}, 580 \mathrm{~m}, 750 \mathrm{~m}$, and $1500 \mathrm{~m}$ flooded with small quantities of water and two temperature recorders at $60 \mathrm{~m}$ and $100 \mathrm{~m}$ failed to record any data at all.

Following the recovery of the Northeast mooring the Oceanus got underway for Madeira. The ship arrived in Funchal, Madeira, at 0800 UTC on 16 February 92 . Work was immediately begun to turnaround the two recovered buoys and instrumentation for deployment on the Northeast and Northwest moorings. Tower tops were removed from the buoys and packed for surface shipment back to Woods Hole. The tower bottom from the Northeast had several cracked welds where the legs intersect the intermediate triangle. This was a one piece unit that had to be repaired in Madeira in June 1991 after being damaged during shipment. One of the welds that was cracked had previously been repaired. The cracked tower bottom was removed and replaced with a newer 


\section{Figure 12. Subduction 2 Central Mooring Schematic}

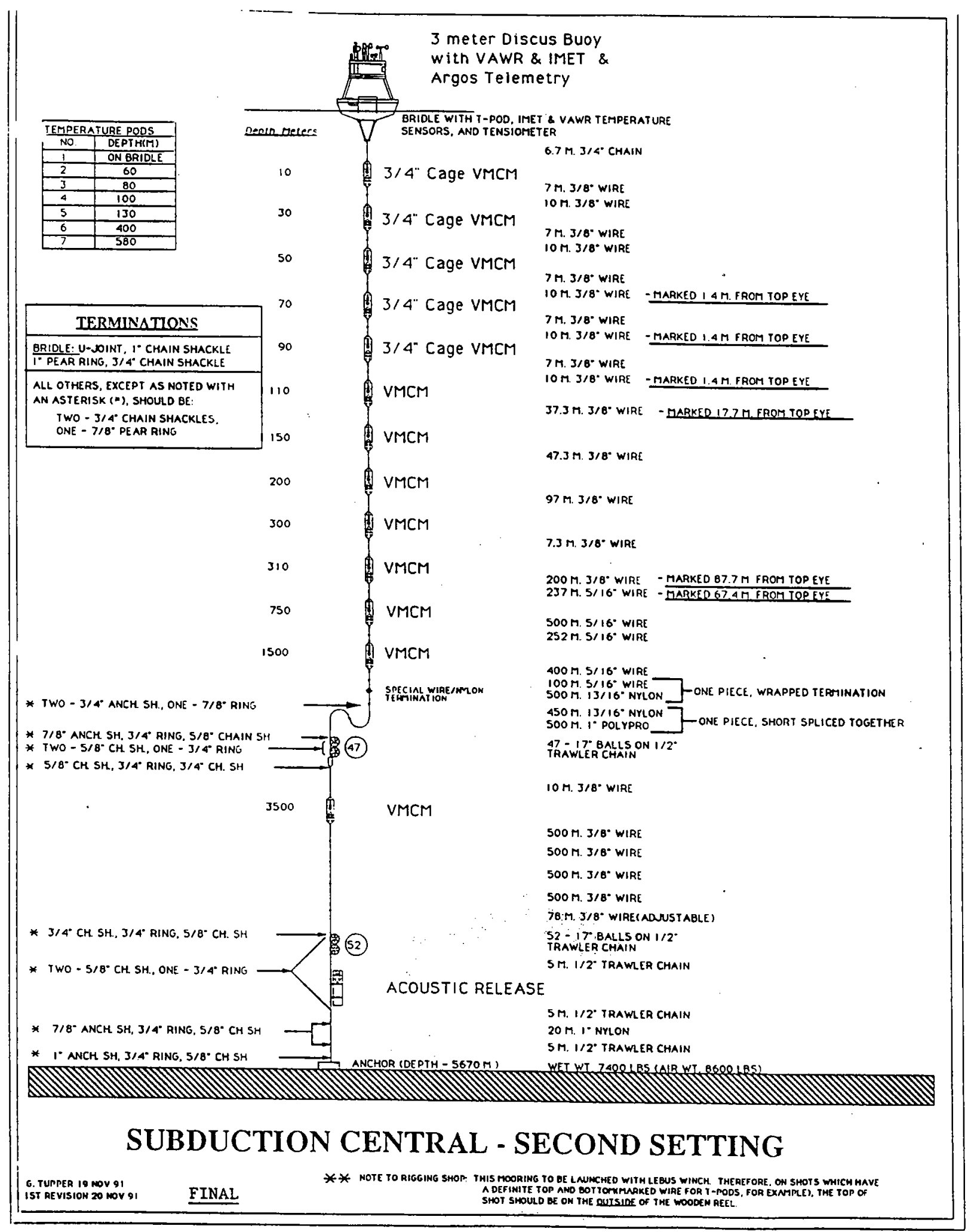


Figure 13. Subduction 2 Central Mooring Acoustic Release Survey

Subduction 2

Central Mooring

Mooring Number 926

Acoustic Release Survey

12 February 1992

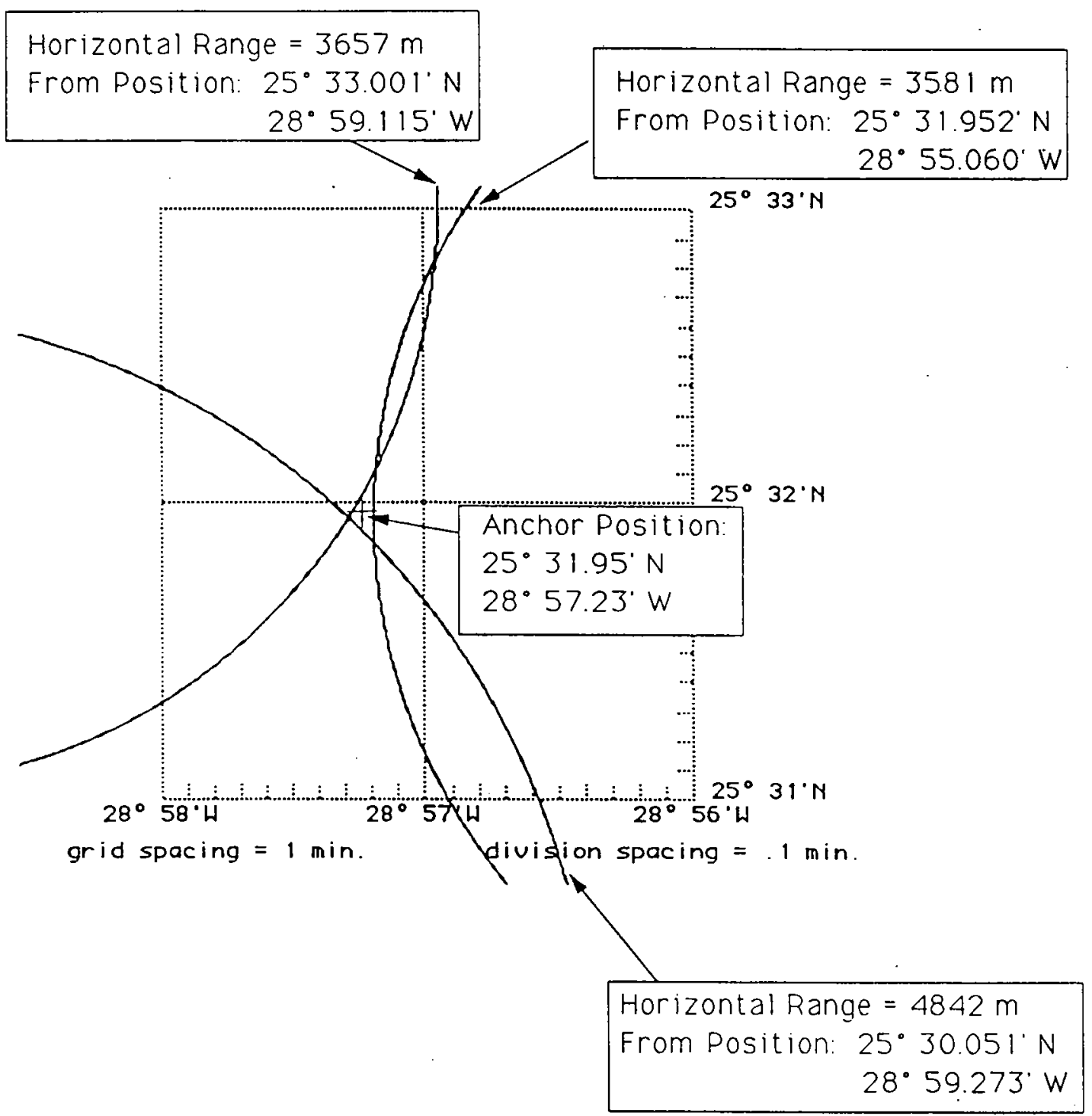


Figure 14. Subduction 1 Northeast Mooring Schematic

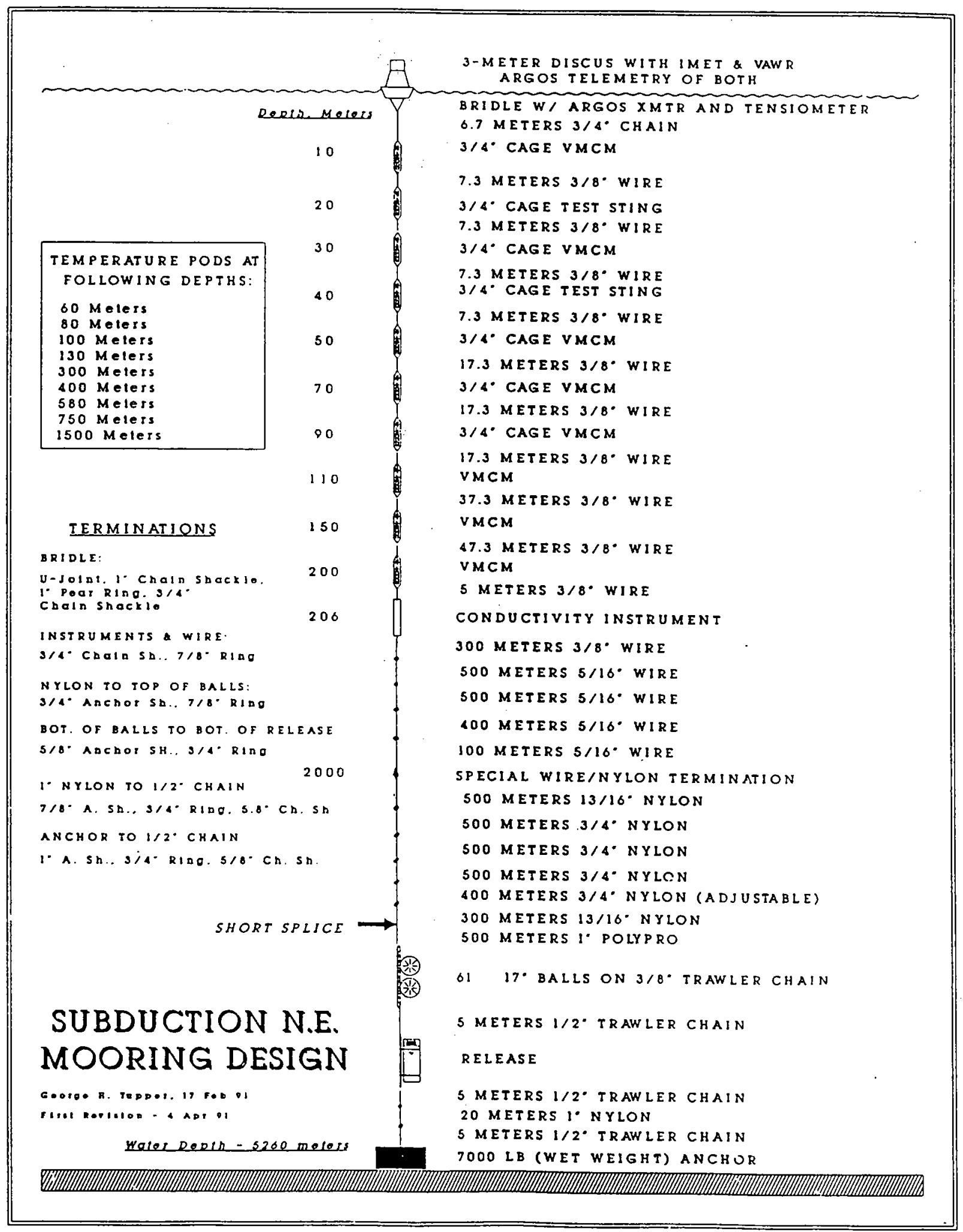


design with independent legs and intermediate triangle. The cracked tower bottom was again repaired and gussets welded in the vulnerable areas. The repaired bottom was a spare in the event that the primary unit was damaged during deployment.

New VAWR Argos transmitters were installed in the buoy wells as were new marine lantern batteries. New fully instrumented tower tops were installed and the meteorological instruments checked out and cabling secured. The IMET LOPACS was working satisfactorily and therefore not changed. The storage batteries were also checked out and they too were found to be in good condition and not replaced.

Five VMCMs (four plus one spare) were turned around for deployment on the Northeast mooring. Two of the four instruments reused the stings that had been previously deployed for eight months. Their condition upon recovery was like new so a decision was made to reuse two of them. The inventory of Brancker temperature recorders was reviewed and a strategy of where to place the remaining WHOI units and SIO units was developed. Instruments were painted with antifouling paint as were the buoy hulls.

The Southwest toroid buoy that was recovered early in the cruise was loaded into a 40 foot container along with a spare toroid anchor, two tower tops, recovered current meters and releases, used wire rope and nylon, and used hardware. The new wire, nylon and anchors for the Northeast and Northwest moorings which had arrived in the same container were loaded onto the ship. The upper part of the Northeast mooring was wound onto the winch. The remaining reels were secured on deck. In all there were three full days of work getting everything ready for the second leg.

The Oceanus departed Madeira at 0800 UTC on 19 February 1992 enroute to the Northeast mooring. The ship arrived at the Northeast site at 0600 UTC on 20 February 92 . As the ship approached the site a brief depth survey was conducted. While on location the set and drift of the ship was established to determine the start position for the mooring work. While steaming into the wind (northeast) at approximately 1 knot the ship was set to the northwest. A start position four miles to the southeast of the target was decided upon.

The deployment commenced at 0915 UTC and proceeded very smoothly. Figure 15 is a schematic of the second setting of the Northeast mooring. The buoy and upper instrumentation went in the water without any problems. Several shots of nylon and the nylon-to-polypropylene shot were wound onto the winch about half way through the deployment. During the deployment of the acoustic release the protective cage around the transducer head was damaged. A replacement was substituted and the deployment continued. Since the bottom was very flat and it was not necessary to hit any particular target the mooring anchor was deployed as soon as it was prepared. The anchor was deployed at 1547 UTC on 20 February 1992.

After the mooring had settled out an acoustic release survey was conducted. The results of that survey are shown in figure 16 . The anchor position for the second setting of the Northeast mooring (WHOI Mooring number 927 ) was $33^{\circ} 01.98^{\prime} \mathrm{N}, 22^{\circ} 00.27^{\prime} \mathrm{W}$. This position is slightly to the north of the original site so as to give some distance between it and a Kiel mooring located at $32^{\circ} 55.3^{\prime} \mathrm{N}, 22^{\circ} 08.17^{\prime} \mathrm{W}$. The Northeast mooring anchor fell back 393 meters or $10.9 \%$ of the water depth. The corrected water depth at the Northeast site was 5274 meters (total correction $=54$ meters) and the sound speed was $1515 \mathrm{~m} / \mathrm{sec}$.

Following the acoustic survey, meteorological observations were taken every 15 minutes for four hours while the ship was within .25 miles of the surface buoy. The Oceanus then got underway for the Northwest buoy at 2152 UTC on 20 February 1992 . Hourly XBTs were resumed at $2300 \mathrm{UTC}$. 


\section{Figure 15. Subduction 2 Northeast Mooring Schematic}

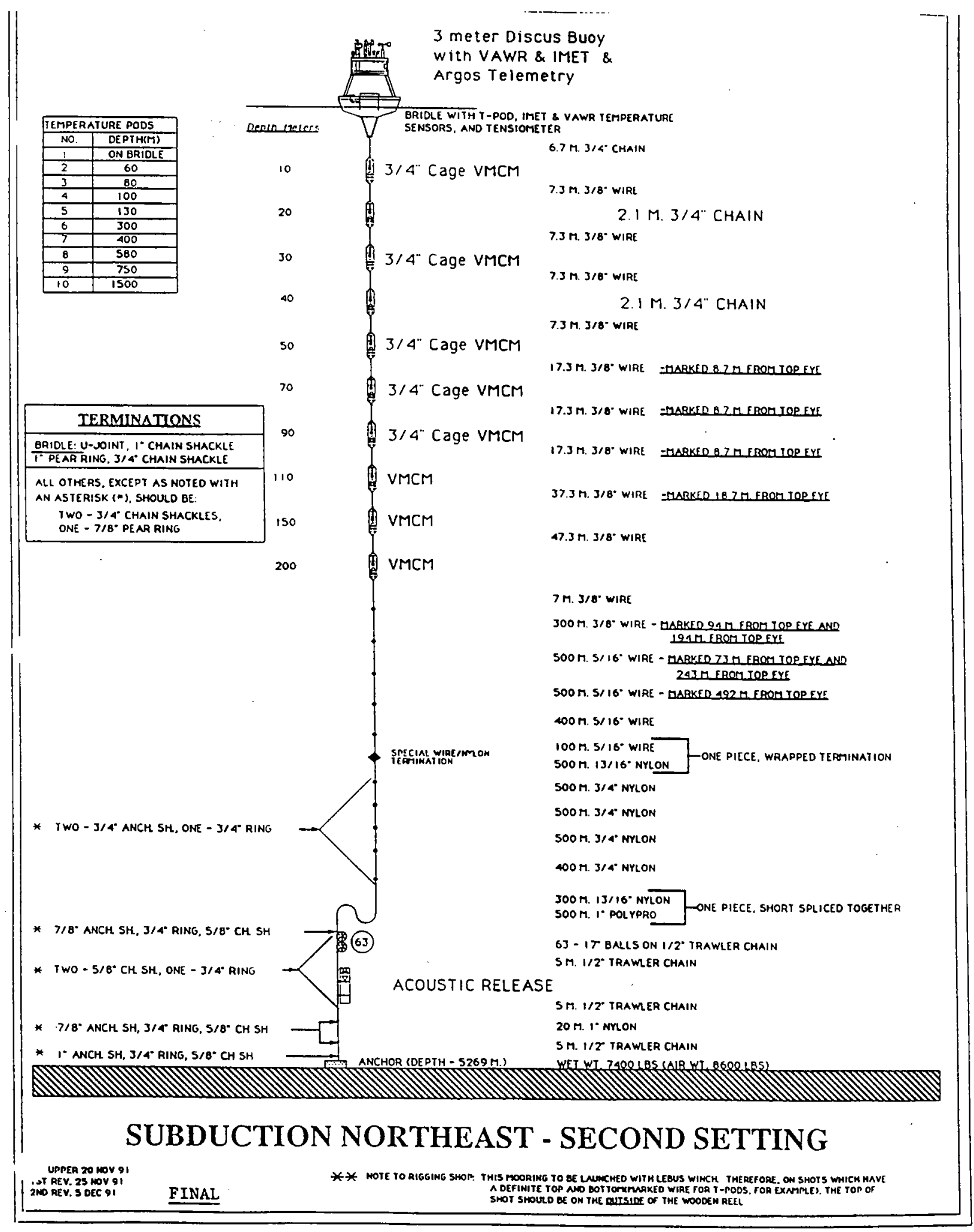


Figure 16. Subduction 2 Northeast Mooring Acoustic Release Survey

\section{Subduction 2 \\ Northeast Mooring \\ Mooring Number 927 \\ Acoustic Release Survey \\ 20 February 1992}

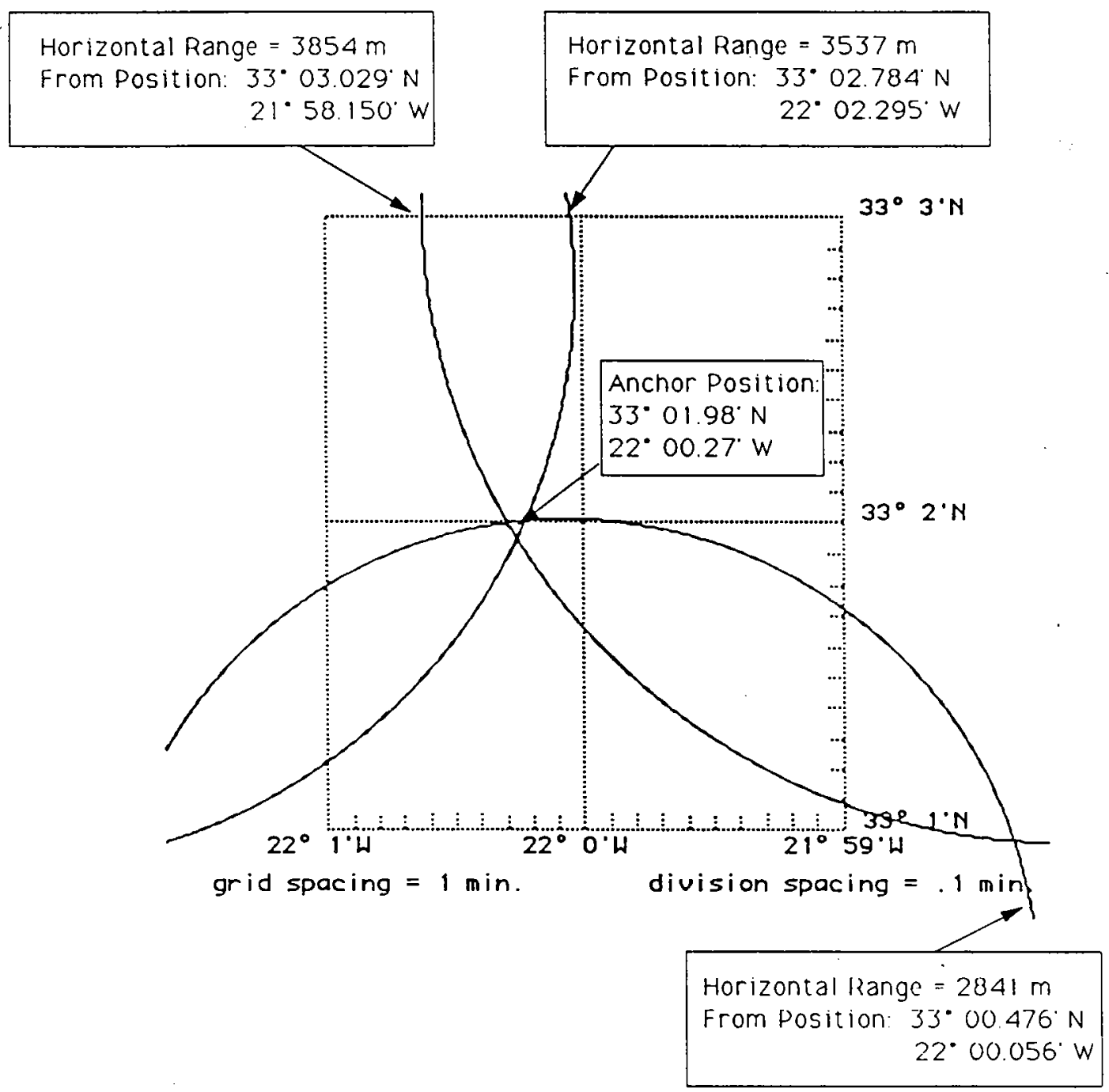




\section{Northwest Mooring}

The ship arrived at the Northwest mooring site at 0230 UTC on 23 February 1992. Since this mooring had parted in August 1991 there was nothing on the surface and it was preferable to wait until daylight before recovery was attempted. While waiting the ship interrogated the release to determine if it was still operable and to see if it was in the same location as when deployed. The release responded without any trouble and was in the same position. A depth survey was conducted to determine the depth variability in the immediate target area. The new mooring design for the northwest site permitted a \pm 60 meters depth window around the design depth without producing any significant effect on the mooring's performance. The area within those limitations was identified as the "strike zone". Deployment anywhere within the "strike zone" would be permissible. Time was also spent determining the set and drift of the ship at the drop site and the start position.

With daylight the ship was positioned .3 miles downwind of the anchor position and the release was fired at 0854 UTC. The mooring was sighted at 0909 UTC and was completely recovered by 1119 UTC. Figure 17 is a schematic of the failed mooring. The upper most part of the recovered mooring consisted of a cluster of four glass balls at $500 \mathrm{~m}$ and above that a wire rope swage with boot and about 3" of wire. The wire appeared as if it had been bent back on itself before parting. Presumably the wire took a turn around the balls, was damaged and then failed.

Two WHOI temperature loggers at $580 \mathrm{~m}$ and $1500 \mathrm{~m}$ and one SIO temperature logger at $750 \mathrm{~m}$ were the only instruments recovered from the parted Northwest mooring during Oc-250. The two WHOI loggers ( $\# 3272$ at $580 \mathrm{~m}$ and $\# 3273$ at $1500 \mathrm{~m}$ ) leaked a small quantity of water and the data could not be read. The SIO instrument had readable data.

With the mooring aboard the wire on the winch was off-spooled, glass balls were transferred to the ball container and the new mooring was wound onto the winch.

A set and drift exercise conducted during the off-spooling and winding indicated that the ship should be positioned to the southeast of the site and steam to the west. A slight northerly current would set the ship to the northwest. The ship was positioned 4 miles downwind of the mooring site to begin deployment.

Figure 18 shows the new mooring design for the second setting of the Northwest mooring. The deployment began at 1756 UTC on 23 February 1992. The upper temperature instruments and buoy were deployed very smoothly. During deployment it was discovered that the 37.2 meter shot of wire was wound onto the winch up side down. The shot was recovered and reversed and redeployed. Later in the deployment there was concern that the 80 meter shot with 7 temperature recorders attached may be inverted. If it is the temperature recorder depths will be recalculated. A recommendation for the future is to mark the top and bottom of critical wire shots that have instruments spotted at particular depths along its length.

The mooring was towed for approximately 45 minutes while the nylon-to-polypropylene shot was wound onto the winch. Deployment resumed and the mooring was again towed with the glass balls and release outboard. The anchor was deployed at 2328 UTC on 23 February 1992.

After the mooring had settled out an acoustic release survey was conducted. The results of that survey are shown in figure 19. The anchor position for the Northwest mooring (WHOI Mooring number 928 ) was $32^{\circ} 54.42 ' \mathrm{~N}, 3^{\circ} 53.35^{\prime} \mathrm{W}$. The Northwest mooring fell back 298 meters or $8.3 \%$ of the water depth. The water depth at the site was 3590 meters corrected (total correction is +13 meters). The sound speed was $1505.4 \mathrm{~m} / \mathrm{sec}$. 


\section{Figure 17. Subduction 1 Northwest Mooring Schematic}

\section{NORTHWEST SUBDUCTION 1 MOORING}

WHOI Mooring No. 918

\begin{tabular}{|l|l|}
\hline \multicolumn{2}{|c|}{$\begin{array}{c}\text { Temperature Pods } \\
\text { No }\end{array}$} \\
\hline 1 & 10 \\
\hline 2 & 30 \\
\hline 3 & 50 \\
\hline 4 & 60 \\
\hline 5 & 70 \\
\hline 6 & 80 \\
\hline 7 & 90 \\
\hline 8 & 100 \\
\hline 9 & 111 \\
\hline 10 & 130 \\
\hline 11 & 300 \\
\hline 12 & 400 \\
\hline 13 & 500 \\
\hline 14 & 750 \\
\hline 15 & 1500 \\
\hline
\end{tabular}

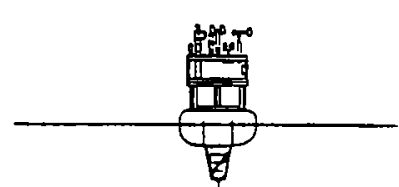

$10 \mathrm{~m}$

$50 \mathrm{~m}$

$100 \mathrm{~m}$

$110 \mathrm{~m}$

$111 \mathrm{~m}$

$130 \mathrm{~m}$

$150 \mathrm{~m}$

$200 \mathrm{~m}$

$A D C P$

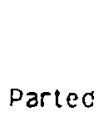

(1)

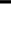

300

$400 \mathrm{~m}$

$580 \mathrm{~m}$

$750 \mathrm{~m}$

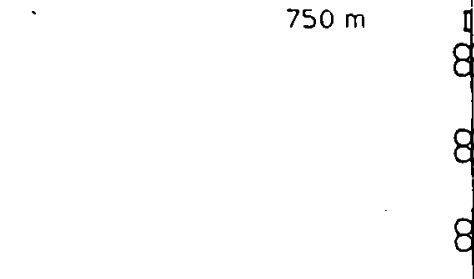

Water Depth $=3608 \mathrm{~m}$
SIO Toroid Buoy

with I VAWR and

Argos Telemetry

Swivel

$6.3 \mathrm{~m} \mathrm{3/4"Chain}$

$101.7 \mathrm{~m} \mathrm{3} / 8^{\circ}$ wire

with 8 Temperalure Recoraers

0 Temperature Pod

1] Temperature Pod

Temperature Poo

Temperature Pod

Temperature Pod

Temperature Pod

Temperature Pod

Temperature Pod

$37.1 \mathrm{~m} \mathrm{3/8"} \mathrm{wire}$

with 2 Temperature Recoroers

$47.3 \mathrm{~m} \mathrm{3/8*}$ wire

(4) $17^{\prime \prime}$ glass balls

$100 \mathrm{~m} \mathrm{3/8"} \mathrm{wire}$

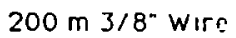

(4) $17^{\circ}$ glass Dalls

$250 \mathrm{~m} \mathrm{3/8"} \mathrm{wire}$

(4) 17" glass balls

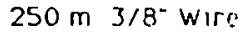

(4) $17 \%$ glass balls

$250 \mathrm{~m} \mathrm{3/8"} \mathrm{Wire}$

(4) $17^{-*}$ glass Dalls $250 \mathrm{~m} \mathrm{3/8"} \mathrm{wire}$

(4) 17" glass Dalls

$250 \mathrm{~m} \mathrm{3/8*} \mathrm{wire}$

(4) $17^{\prime \prime}$ glass balls

$250 \mathrm{~m} \mathrm{3/8}$ "Wire

(4) $17 \%$ glass balls $500 \mathrm{~m} \mathrm{3/4"} \mathrm{Nylon}$

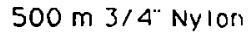
$500 \mathrm{~m} \mathrm{3/4"} \mathrm{Nyion}$ $10 \mathrm{~m} \mathrm{3/4"Nylon}$ Swivel

(8) $17^{\prime \prime}$ qlass Dalls

$20 \mathrm{~m} \mathrm{3/8^{ \circ } \text { Wire }}$

Acoustic Release

$4 \mathrm{~m} \mathrm{3/4"Criain}$

Swivel

$30 \mathrm{~m} 9 / 8^{\circ}$ Nylor.

$30 \mathrm{~m} \mathrm{3/4"} \mathrm{Chain}$

$30 \mathrm{~m} \mathrm{3/4"} \mathrm{Chain}$

6000 pound Anchor 
Figure 18. Subduction 2 Northwest Mooring Schematic

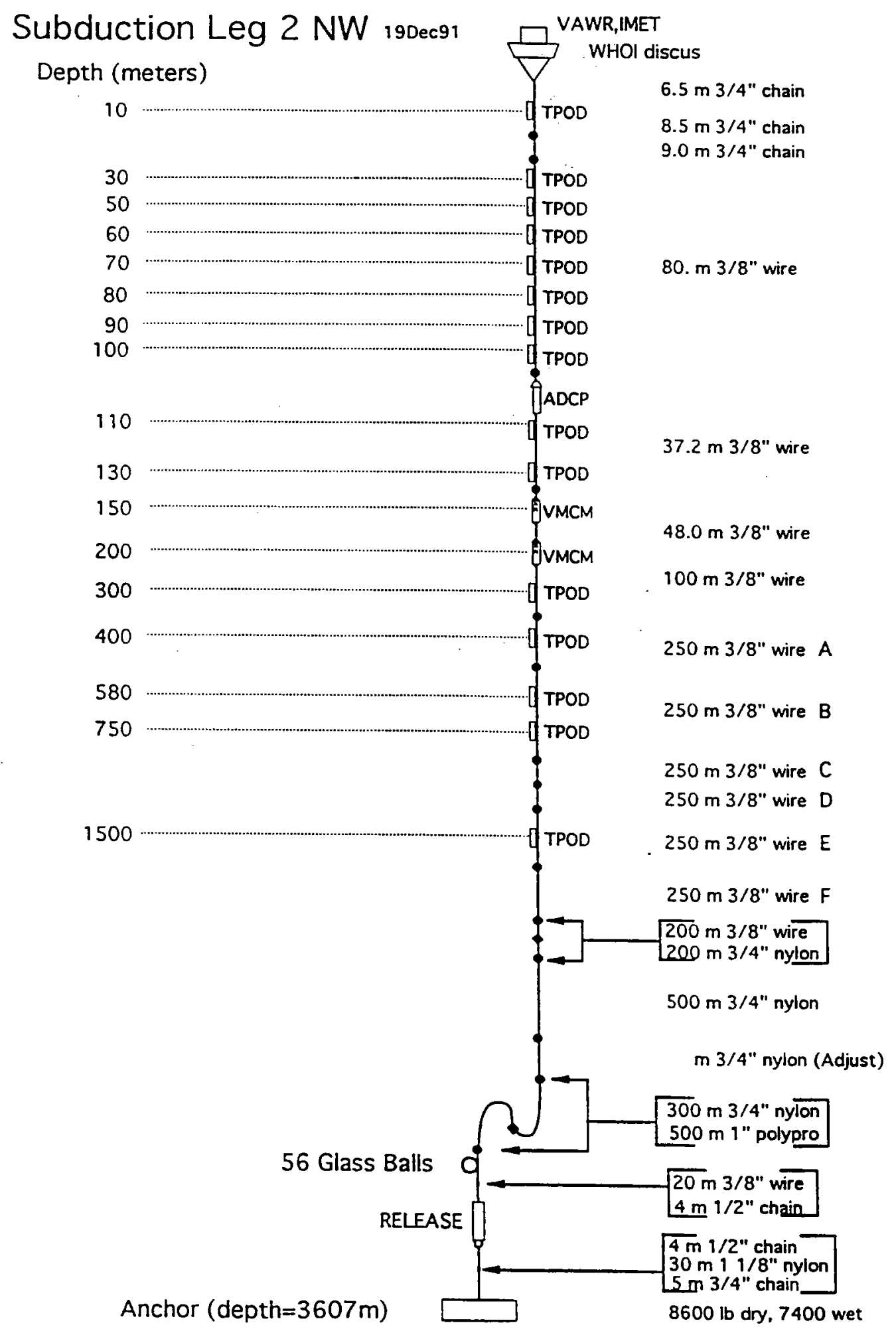


Figure 19. Subduction 2 Northwest Mooring Acoustic Release Survey

Subduction 2

Northwest Mooring

Mooring Number 928

Acoustic Release Survey

23 February 1992

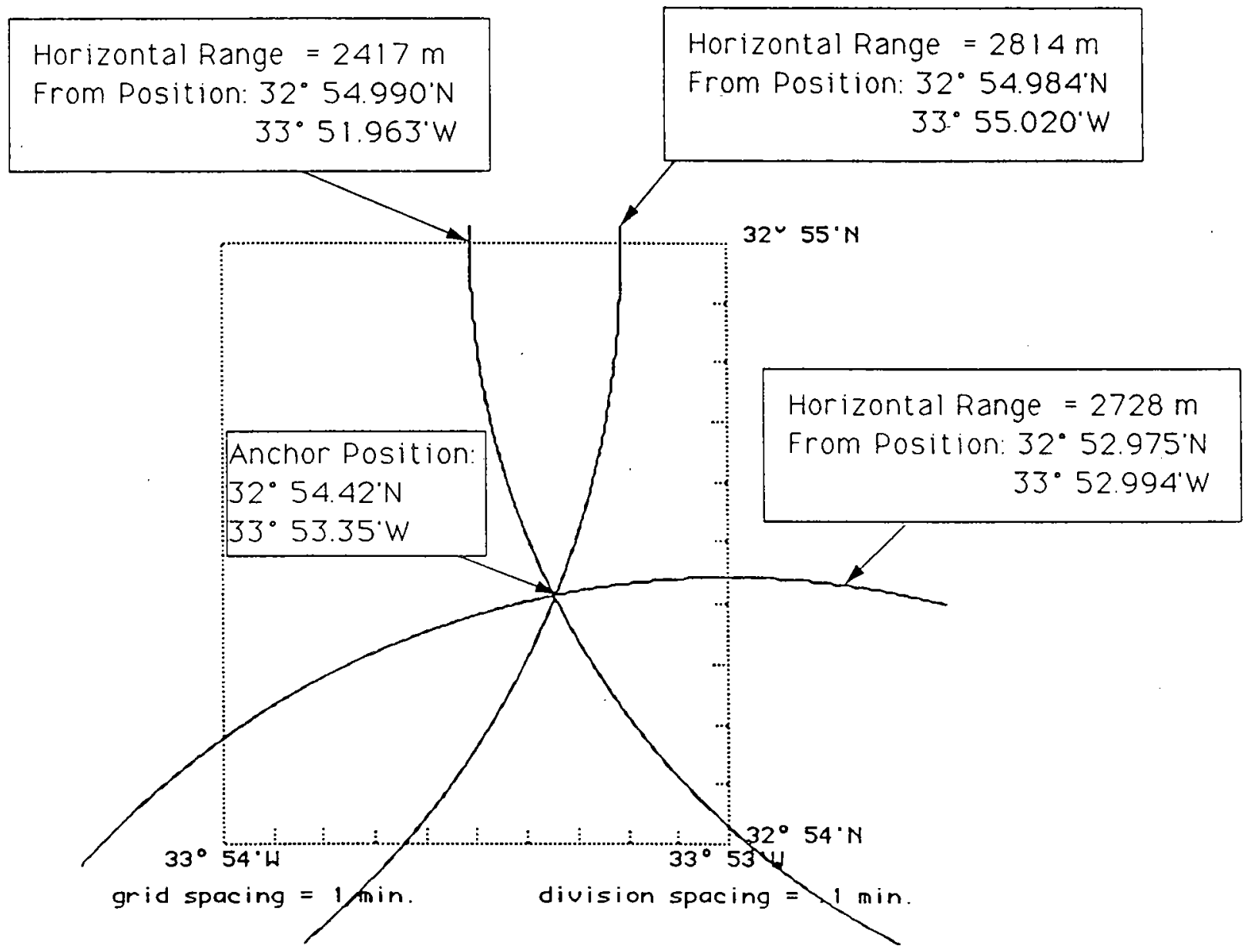


Meteorological observations were taken every 15 minutes for four hours while the ship was positioned .25 miles downwind of the buoy. At 0545 UTC 24 February 1992 the ship got underway for Ponta Delgada, Azores. Hourly XBTs were resumed at 0900 UTC with the last XBT deployed at 2000 UTC. The ship arrived in the Azores on 26 February 1992 at 0900 UTC.

\section{References}

Trask, Richard P., Jerome P. Dean, James R. Valdes, and Craig D. Marquette, 1989: FASINEX (Frontal Air-Sea Interaction Experiment) Moored Instrumentation. Woods Hole Oceanographic Institution Technical Report, WHOI-89-3, 60 pp.

Trask, Richard P., and Nancy J. Brink, 1993: The Subduction Experiment, Cruise Report, R/V Oceanus Cruise Number 240, Woods Hole Oceanographic Institution Technical Report, WHOI93-12, 77 pp.

\section{Acknowledgements}

The WHOI moorings deployed during Oceanus cruise number 250 were expertly designed by George Tupper and carefully prepared by the WHOI Rigging Shop under the direction of David Simoneau. The instrumentation that was deployed on these moorings was carefully prepared by Bryan Way and Paul Bouchard. They both provided invaluable assistance throughout the entire cruise.

We are grateful for the skill of Captain Paul Howland and the friendly assistance provided by all the crew members of the R.V Oceanus. Will Ostrom was instrumental in preparing the buoys for deployment and in supervisiong the recovery and deployment operations during the cruise. Glenn Pezzoli from Scripps Institution of Oceanography was helpful both on deck and in evaluating several instrumentation problems. Bob Weller's attention to detail prior to and throughout the cruise greatly benefited the project as instrumentation was prepared. Long hours spent by Nan Galbraith in the noisy lower lab of the Oceanus upgrading software and processing data is also greatly appreciated. We sincerely thank Mary Ann Lucas for her help in preparing this report.

This work was supported by the Office of Naval Research Grant No. N00014-90-J-1490. 


\section{Appendix 1 \\ Cruise Participants}

Robert A. Weller, Chief Scientist

Richard P. Trask

William Ostrom

Bryan Way

Paul Bouchard

Neil McPhee

Nancy Pennington

Nan Galbraith

Lloyd Regier

Glenn Pezolli
(WHOI)

(WHOI Research Specialist)

(WHOI Senior Engineering Assistant)

(WHOI Engineering Assistant)

(WHOI Engineering Assistant)

(WHOI Engineering Assistant)

(WHOI Senior Research Assistant)

(WHOI Information Systems Associate)

(SIO Design Engineer)

(SIO Development Technician) 


\section{Appendix 2 SIO Mooring Design}

The Instrument Development Group (IDG) of Scripps Institution of Oceanography prepared three surface moorings and provided the associated instrumentation for the first Subduction deployment. In Subduction 2 these moorings were recovered, the data extracted from the instruments, and the moorings and instruments were redeployed for another eight months.

\section{SUBDUCTION 1 SURFACE MOORINGS}

The IDG surface moorings were supported by a toroid buoy with a diameter of 2.4 meters. A triangular tower on top of the buoy supported IMET and VAWR instruments measuring meteorological variables. Solar panels were used to provide power for the IMET package and the associated ARGOS satellite transmitters which relayed the data to shore-based observers. An auxiliary lead-acid battery pack was installed in the bridle beneath the buoy to provided power during periods of low solar energy. These additions to the IDG toroid weighed a total of 1900 pounds which left the buoy with a reserve buoyancy of only 4200 pounds with which to support the mooring. By comparison, a similarly loaded WHOI discus buoy has a reserve buoyancy of 8700 pounds.

As these moorings were being designed, several key mistakes were made in an attempt to make these moorings survive the high currents which often characterize regions near fronts. The effective scope of the mooring was increased by adding 60 to 90 meters of $3 / 4$ inch chain to the bottom of the mooring just.above the anchor. This improved the holding power of the anchor by making the force on the anchor more horizontal. However it increased the weight of the anchor by so much that the toroid was incapable of supporting the mooring if it drifted into deep water. The increased anchor weight also increased the falling velocity of the anchor during launch.

The second mistake was that floatation, rather than being concentrated near the anchor, was distributed throughout the wire rope in the upper part of the mooring. This reduced the tension at the base of the surface float and thus made the mooring capable of standing large currents. But it also decreased the drag near the anchor which further increased the fall velocity of the anchor.

Some of the ramifications of these design errors became apparent as the moorings were deployed. The low static tensions at the base of the surface toroid, which were needed to make the overloaded buoy withstand the expected currents, gave little righting moment to the surface float. Thus the mooring had to be paid out very slowly. The multitude of flotation elements in the wire rope section resulted in multiple catenaries of wire hanging beneath the floating glass balls. One could not simultaneously maintain sufficient way on the ship to keep the catenaries from tangling without increasing the danger of capsizing the surface buoy. When the anchor was deployed, the terminal velocity of the very heavy, low drag anchor was truly astounding and resulted in the buoy being towed across the surface at speeds near 4 knots. This raised the drag-induced tension in the mooring and stretched the nylon sections much more than had been anticipated. Once the anchor had settled into the bottom, the stretched nylon began to contract. But the buoy was still out at the limits of its watch circle and was only barely at the surface. As the nylon contracted and the force on the buoy became more vertical, it pulled the buoy under the surface a few meters for a few minutes. It slowly surfaced as the buoy moved closer to the anchor position. The short term submergence of the buoy had a rather disastrous effect on the meteorological instruments.

Ultimately the folly of the mooring design became more evident as the moorings parted and began drifting around the Atlantic Ocean. The upper portion of the Northwest mooring (NW) was recovered by Woods Hole personnel onboard R. V. Endeavour. Part of the Southeast (SE) 
mooring was recovered by the Russian vessel Mendeleev and another portion was recovered from the shoals of the Cape Verde Islands by a local tug boat and diver. The upper portion of the Southwest mooring (SW) was recovered by R.V. Oceanus during Oc-250. The remaining portions of all three moorings were also recovered by Oceanus in this cruise. Ultimately all the pieces of all the moorings were recovered and examined to discover the causes for the failures. It appears that the moorings failed for two different reasons.

The NW mooring parted in a wire rope section about .3 meter away from a set of glass balls at 500 meters depth. The jacket on the rope was scratched and the wire itself bent in a tight radius which indicates that it may have tangled on a shackle during deployment. When the anchor was dropped, the wire was damaged when it kinked around this shackle and then ultimately failed a month later.

The SW and SE moorings failed in a different manner. Both these moorings parted at the base of a current meter to which was attached a set of glass balls. In both cases the set of glass balls was the shallowest set in the mooring, at 50 meters in one case and 110 meters in the other. In both cases some of the termination hardware, shackles or master links, were missing and the glass balls were heavily damaged. Both of these current meters were also severely damaged and the stings holding their propellers were missing. The explanation for this failure mode lies in the dynamic response of the mooring to wave-induced motion of the surface buoy. As waves move the buoy up and down, the wire rope attached to the buoy is moved vertically. The wire itself has very little drag and can't stretch so the vertical motion propagates downward through the mooring until the current meter just above the first set of glass balls is reached. The current meter is being yanked up and down by the wire from above. However, by design, the mooring tension is very low, too low to accelerate the glass balls downward sufficiently to keep the current meter from capsizing from its normal vertically upright position. When the crest of the next wave pulls the surface float upwards, the current meter is suddenly pivoted upwards, the slack is taken up with a slam, and the connection between the current meter and the glass balls is stressed impulsively. After several thousand such cycles, the hardware is hammered to extinction and fails.

\section{MOORING IMPROVEMENTS FOR SUBDUCTION 2}

As the fundamental cause for the mooring failures was the inadequate displacement of the surface toroid, in the Subduction 2 redeployments, two of the surface toroids were replaced by WHOI discus buoys which have an additional 4000 pounds of reserve buoyancy. No discus or other float was available to replace the third toroid. Rather than attempt to patch together a way to increase the displacement of the toroid, we reduced the load on the toroid by removing the IMET package and its associated lead-acid battery package. This reduced the payload by 700 pounds. However because of concerns that the toroid might capsize during a deployment in heavy seas, a lead counter weight was added to the base of the buoy bridle; this decreased the net payload to about 450 pounds less than that of the Subduction 1 configuration. An additional 1200 pounds of buoyancy was added by installing a ship's fender inside the central well of the toroid.

On all three moorings the glass balls were concentrated in a single mass above the release and anchor. Rather than getting extra scope during periods of high current by lifting a heavy chain off the bottom, a WHOI inverse catenary mooring design was used. A long section of buoyant line provided the extra line needed to increase the scope without creating opportunities for the line to snag on hardware terminations. This required the installation of two special terminations which had been developed at WHOI, a wire-to-nylon junction and a nylon-to-polypropylene junction. These terminations have proved successful in several WHOI moorings in rather difficult environments where more conventional approaches have failed. While the Subduction 1 moorings had a slack scope of .96 , the Subduction 2 toroid mooring had a slack scope of 1.01 . The extra scope also provided a greater tolerance for irregularities in the bottom profile. The glass ball buoyancy was increased on all moorings so that the entire mooring would float in water of infinite 
depth. All of the glass ball flotation was installed directly above the acoustic release and anchor. This reduced the holding power of the anchor but allowed the surface buoy to remain afloat should it hop into deeper water.

The deployment of the Subduction 2 moorings went without incident. The NW and SE moorings were supported by WHOI discus buoys. Only the SW mooring had a SIO toroid. When the SW mooring was deployed, the speed of the toroid through the water was a more sedate 1-2 knots which resulted from the reduced effective weight and increased drag of the anchor caused by moving the glass balls to just above the anchor. As the SW toroid was settling into position, there were several anxious minutes as the toroid rode very low in the water until it had moved from the periphery of its watch circle to a position closer to the anchor. Once it had settled, the toroid was riding very much like it had in previous deployments where it had survived 20 foot seas and 50 knot winds in the Gulf of Alaska. 


\section{Appendix 3 \\ IMET Buoy Systems}

Subduction 2 IMET/LOPACS status

The first turnaround of the Subduction buoys involved replacing the Southeast and Northwest toroids with discus buoys and "turning around" the existing discus buoys at the Central and Northeast positions. The Southwest buoy remained a toroid and was not fitted with an IMET system. This report will deal with the status of the recovered IMET modules and LOPACS and problems or fixes with the newly deployed systems.

Two complete buoys with IMET/LOPACS systems were assembled and tested at Woods Hole. The LOPACS used in these buoys were primarily assembled from existing spares and previously used ARAMP boards. Care was taken to ensure that the components were all properly modified to current standards. Two tower tops were also assembled to be used as replacements for those on the presently deployed discus'. Post assembly testing of the buoys and tower tops was completed and they were loaded aboard the Oceanus.

2 Feb. 1992: The first to be recovered was the Southwest toroid. It had broken free of its mooring and was drifting. It had also gone subsurface after anchor launch last June. IMET ARGOS transmissions from this buoy had ceased just after this but had resumed a week later. The transmissions were only half frame but contained some reasonable data. After the buoy was recovered and set on deck the LOPACS enclosure was opened and a visual inspection made. The only sign of water having gotten in was a slight bit of corrosion on the main power connectors on the power regulator boards. The lights were observed to flash on the $485 / 232$ converter indicating the system was still working. However when an attempt was made to monitor/communicate with the system via the external console cable the LOPACS began to experience hang-ups, i.e. the program would begin to run but stop after the first minute of module interrogation, it could not be restarted by keyboard commands so module status could not be checked at that time. It was possible to exit the program during initialization to check the Date/time. This was 20 secs faster than the standard (Heath GC-1000).

The Optical disk was easily removed for analysis. An initial check showed files were still being written the morning of recovery. Further investigation revealed that no short files were written from 25 June (launch) until 2 July. (See pg. 1, appendix).

It does not appear that much of the data written to optical is usable. A better understanding is gained by looking at the plots of the data but briefly it seems that only SWR returned good data until it quit in January.

After the tower top was removed and set on the lab van for transit to Madeira a cable was run from it to the main lab and each module interrogated via Procomm with the following results: WND: Answered all commands o.k. Compass and vane outputs varied as expected. The propeller was pretty much frozen with salt and would not spin freely.

HRH: Answered all commands o.k. Values pretty much in agreement with Ships' IMET system and varied in test mode. (ship: $81.4 \% / 23.183 \mathrm{deg}$; buoy: $84.8 \% / 23.284 \mathrm{deg}$ )

TMP: Answered all commands (ship: $23.234 \mathrm{deg}$; buoy:23.389 deg).

LWR: Answered all commands, output seemed reasonable, varied in test mode.

PRC: Answered all commands, raw values are all negative, no change when water was added to sensor.

SWR: No response. 
SST: Checked in main lab. Disassembled and found no sign of water. Had problems when communications were attempted, almost seemed as if the program were stuck in a loop. Removed program eprom and reinitialized and it began working o.k.

PTT: All responses good, power out $>1 \mathrm{~W}$, went to multiple id's and full frames when commanded.

These modules will be examined more closely and recalibrated but it seems that the initial submergence caused some problems which need to be better understood. 12.45 .

Both Junction boxes were clean and dry and the battery voltages were between 12.30 and

There is no explanation at present for the inability to communicate with the LOPACS after recovery but this may be due to either the physical jarring of the buoy during recovery or it's angle while secured on deck. wind prop.

All the modules and brackets were secure and intact, the only obvious problem being the

9 Feb. 1992: Deployed new Southeast Discus. This was one of the buoys which had been assembled and tested at Woods Hole. It worked properly when powered up. Observed and checked disk writes. ARGOS transmissions were good on all 4 id's. Rechecked 0 and nominal load of $700 \mathrm{lbs}$ on tension. Post deployment meteorological observations and ARGOS monitoring compared well.

11 Feb. 1992: Recovered Central discus. ARGOS transmissions were received when the buoy was in range (Woods Hole had reported that no transmissions had been received from Service ARGOS since 4 Feb.). Communications were established via ext. con. cable with LOPACS and Subduct.exe was observed to be running properly with only SST not responding. A check of DatelTime showed the following discrepancy:
LOPACS time:
2/13/92 16:53:16
Std time:
2/11/92 16:55:00

This shift occurred 1 week after deployment and had been noticed via ARGOS at that time. The clock/backup battery voltage was $3.02 \mathrm{v}$ at recovery with $3.0 \mathrm{v}$ being nominal. This could possibly be due to a recently found artwork mistake on the LOPACS memio board which had the clock driven watchdog circuit tied to the battery side of the isolation diode instead of the backplane $5 \mathrm{vdc}$. But I feel that while this is a possibility it is remote. This shift had not been observed in any other LOPACS with the same board error.

There were no missing files and data quality appeared good. Problems were noted with the following modules:

SST: Ceased functioning $27 \mathrm{July}$. When disassembled it was found to contain about $1 / 4$ cup of water. This water had set in the bottom of the module so there was not much corrosion on the boards themselves but the wires to the Sea-Con connector were quite corroded and the power wire had separated from its' solder cup.

SWR: Quit 4 Nov. Had been working fine until then. Have not investigated yet.

General: $\quad$ Sensor J-box was clean and dry.

Solar J-box had a little water in it and some corrosion but since the regulators are encapsulated it was still working. The $O$ ring and mating surface were intact, the lid was tightly fastened and the Woodheads and cable stoppers were tight and undamaged. It is possible the water could be coming through the cable from the panels and this will have to be looked at.

Gel Cells: Voltages were between 12.4 and 12.7.

This buoy was to be turned around and used as the Northwest (a change in plan as it was originally to become the Northeast). Since the LOPACS had worked properly, the time shift notwithstanding, it was readied for reuse. This involved modifying the artwork on the memio and adc boards, installing new Subduct.exe eproms, and memory back up batteries. A close physical 
inspection at this time showed no signs of corrosion or damage. It was connected to the tower top still on the lab van for burn-in. No problems were noted.

The original Central discus PTT was inspected and reprogrammed to become the new Northwest PTT.

12 Feb. 1992: Deployed Central Discus. This was the other complete buoy which had been assembled and tested at Woods Hole. After it was restarted the PTT began to occasionally cease transmitting but then restart. A complete system power cycle would always return it to proper operation but it would again cease after a few hours. The PTT which had been recovered from the Southwest and had worked properly for the last 8 months was prepared, reprogrammed and installed. No further ARGOS problems were noted.

Pre-deployment checks of modules, disk operation and tension were all good.

Post deployment via ARGOS showed a good intercomparison with VAWR and meteorological observations. The tension appeared high however.

15 Feb. 1992: Recovered the Northeast Discus. ARGOS transmissions since last October seemed to indicate the LOPACS was resetting itself at irregular intervals. Analysis of the optical disk showed some files missing followed by short files in a manner which indicated that disk drive hangups were causing the resets. This, however, did not result in much data lost and all of the modules performed through to the end.

The LOPACS time was $1 \mathrm{~min} .52$ secs behind the standard time. There were no signs of corrosion or damage to the LOPACS. This buoy was to be redeployed as the Northeast. The optical disk drive and controller board were replaced in the LOPACS in addition to the previously mentioned turn around requirements.

The on deck tension check indicated a problem with the system. A shorting plug was installed at the input to the LOPACS a/d and the signal via ARGOS did go to 0 . When the cable from the buoy well to the tension cell itself was rung out an open was found in the common lead. The cable was replaced but tension was still not responding properly. Temporarily connected the spare cell with good results. The old cell was removed and replaced with the spare.

General: $\quad$ Sensor J-box was clean and dy.

Solar J-box had about same amount of water as Centrals.

Again there were no obvious paths for water entry.

Gel Cells: Voltages were between 12.25 and 12.40 .

This buoy was redeployed $20 \mathrm{Feb}$. The shipboard meteorological observations compared well with the ARGOS transmitted IMET data.

(23 Feb. 1992: Deployed Northwest Discus)

General Notes: As with the previously returned Southwest toroid all the buoy hardware was in good shape. The solar panels were secure and undamaged as were any exposed cables. None of the brackets showed any cracked welds or loose fastenings. 


\section{Appendix 4 \\ Wind Direction Comparison Tests}

Part of the preparation of the meteorological packages includes checking the wind direction sensors. This consists of placing each buoy on a test station that can be rotated through $360^{\circ}$ and directing the wind vane to a fixed target at $60^{\circ}$ intervals. The direction is then computed from the instrument compass and vane direction data.

The test site in Woods Hole was located at the southern corner of the Clark - South Laboratory parking area. This site showed little horizontal or vertical spatial variation in the magnetic field. The tower tops ( 3 of which were on buoys) were mounted each in turn on a wooden and masonite turntable, and the direction of a tree near the Clark building was measured from six orientations. At each of the six positions the wind vane was aligned to the tree by eye and locked in position. The data was then read directly from the instrument. In the case of the VAWR the compass and vane positions are added to obtain the wind vane direction in oceanographic convention (i.e. the wind direction of flow from the north is $180^{\circ}$ ). The magnetic bearing to the tree from the test site is $309.0^{\circ}$. Figures A4-1 to A4-5 show the results of those spin tests for the Subduction 2 VAWR and IMET direction sensors. 
Figure A4-1. Wind Direction Comparison Test for Subduction 2

Southwest Buoy.

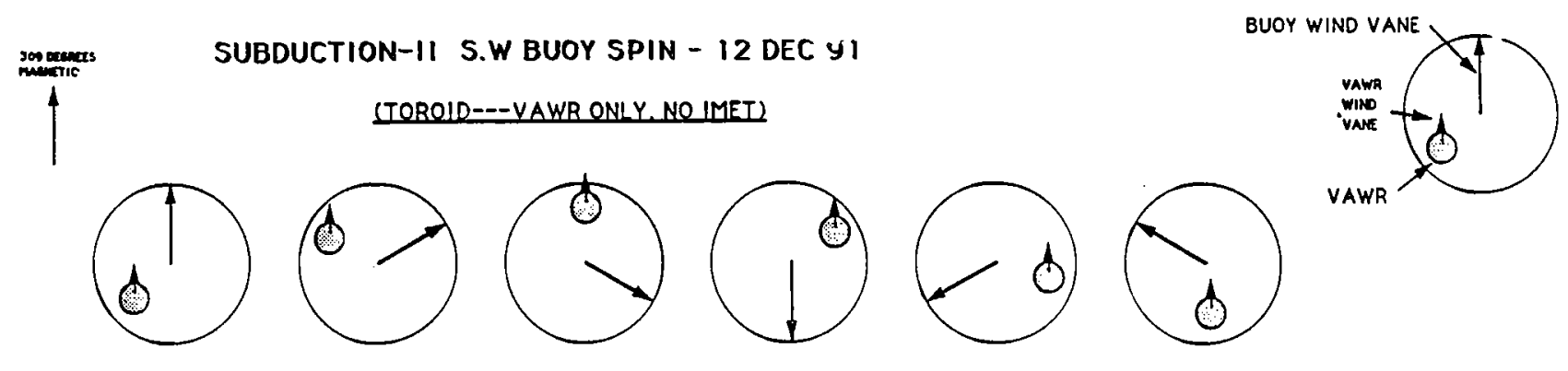

-BEARING - ALGEBRAIC SUM OF INST ANTANEOUS COMPASS AND VANE

VAWR MAG. BEARING

(DEGREES

320

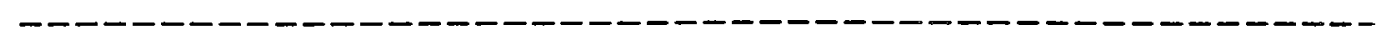

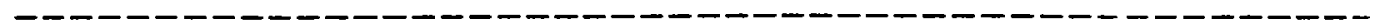

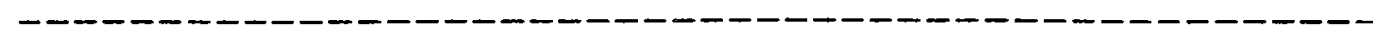

310

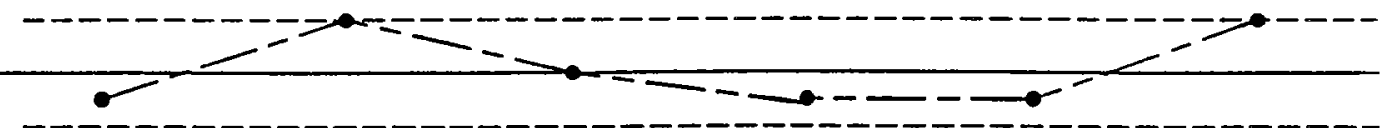$$
-
$$

300

a.rumen 17 axe 9 
Figure A4-2. Wind Direction Comparison Test for Subduction 2 Southeast Buoy.

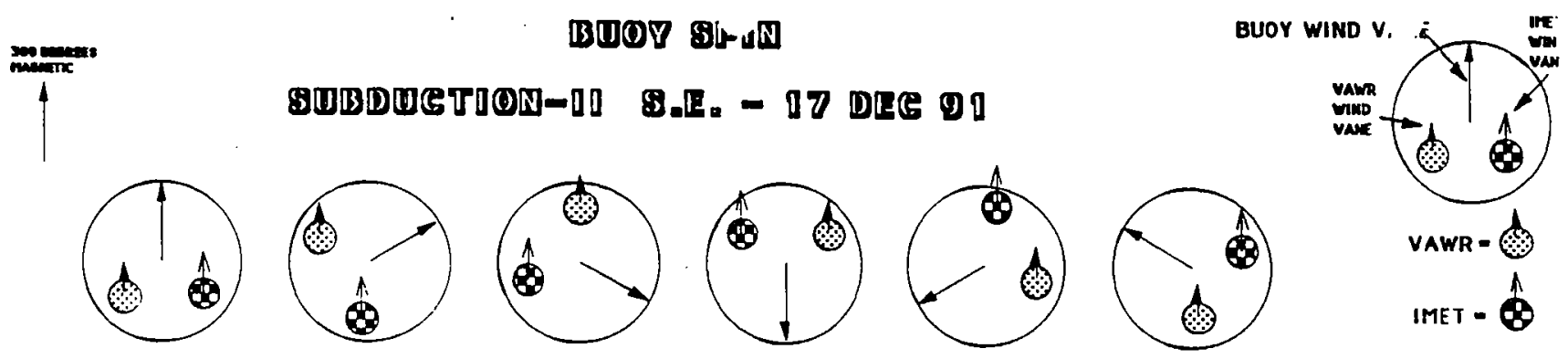

-BEARING - ALgebraIC SUM OF INSTANTANEOUS COMPASS AND VANE

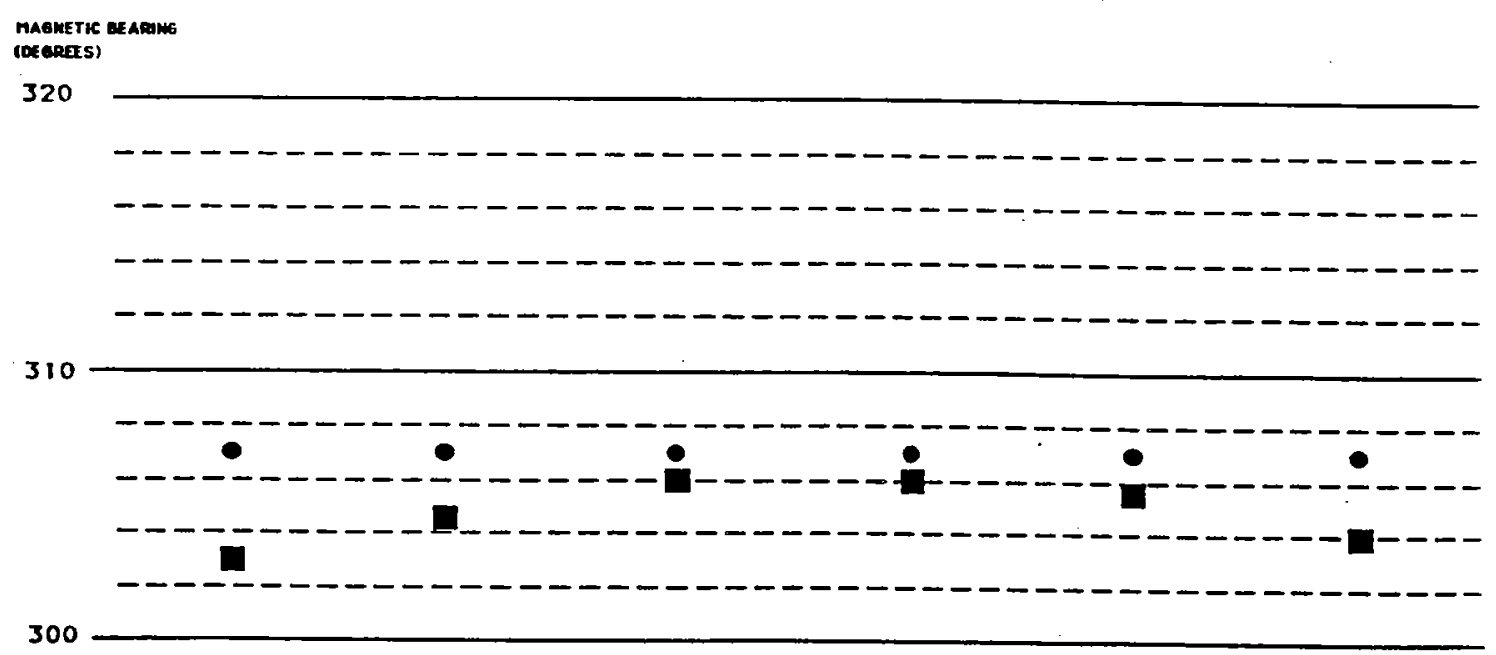


Figure A4-3. Wind Direction Comparison Test for Subduction 2

\section{Central Buoy.}

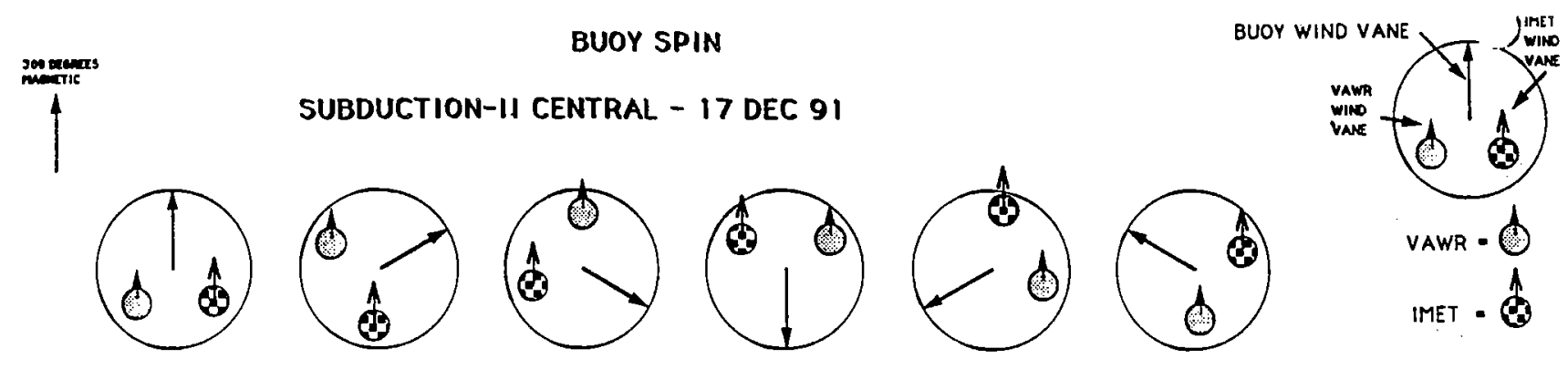

-BEARING - ALGEBRAIC SUM OF INSTANTANEOUS COMPASS AND VANE

MAGNETIC BEARING

(DEEAEES)

320

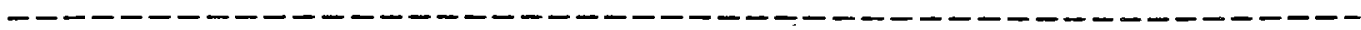

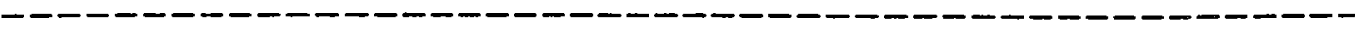

- - - - - - - - - - - - - - - - - - - - - - - -

- vawr data

- - - - - - - - - - - - - - - - - - - - - - - - - - - - - - -

D- IMET DATA

310

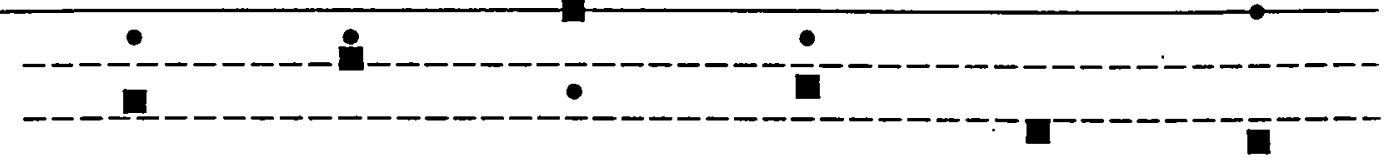

300

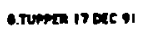


Figure A4-4. Wind Direction Comparison Test for Subduction 2 Northeast Buoy.
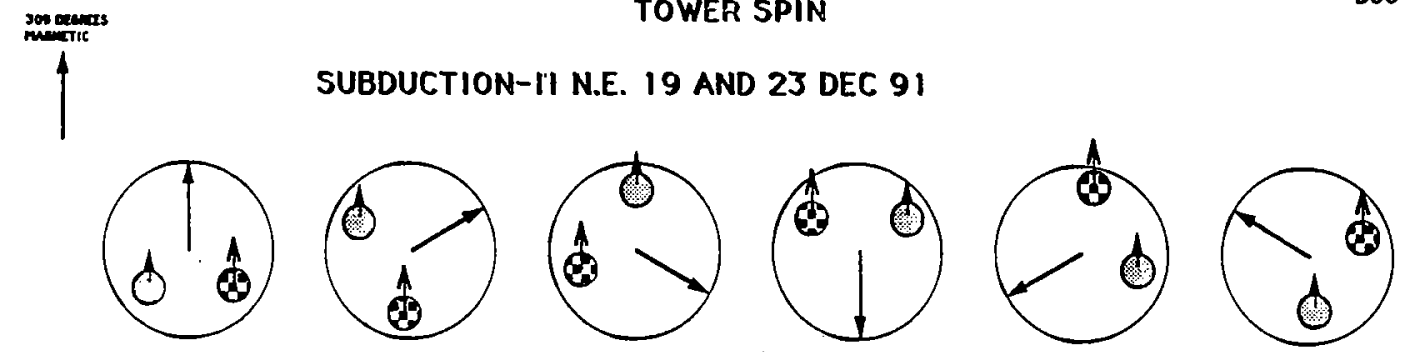

NOTE - VAWR DATA WAS BAD ON THE FIRST SPIN DONE ON 19 DEC 91 . THE VANE FOLLOWER WAS REPLACED AND THE TOWER SPUN AGAIN ON 23 DEC. THE IMET DATA IS FROM I9 DEC, THE VAWR FROM THE 23RD.

-BEARING = ALGEBRAIC SUM OF INSTANTANEOUS COMPA5S AND VANE

\section{maGmetic DeARING}

CDEcress)

320

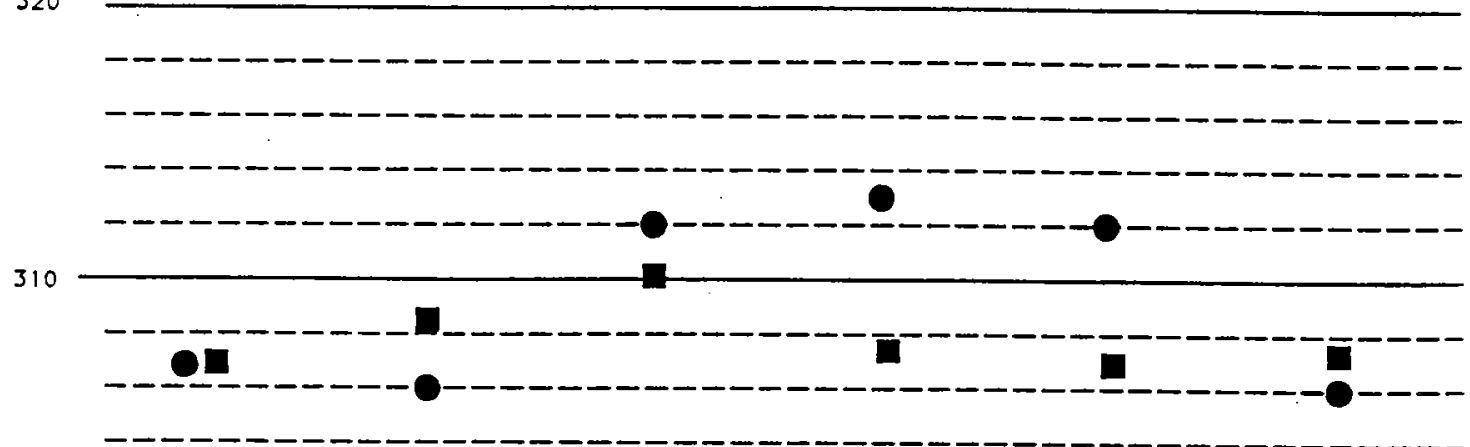

300 -imet data 19 DeE 91

-vawh data 23 dec 9 
Figure A4-5. Wind Direction Comparison Test for Subduction 2

Northwest Buoy.

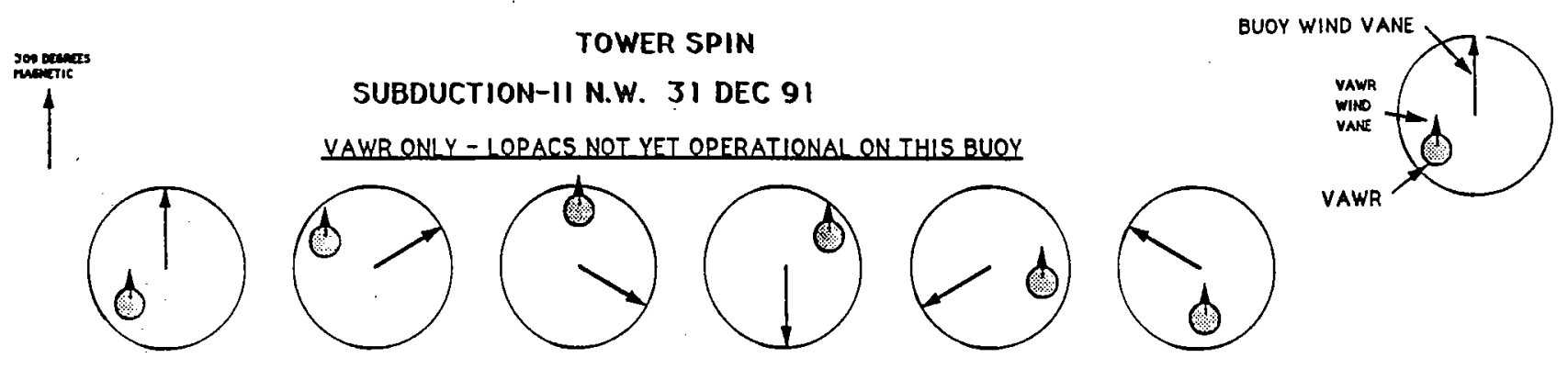

"BEARING - ALGEBRAIC SUM OF INSTANTANEOUS COMPASS AND VANE

VAWR MAG. BEARING

(OEGREES)

320
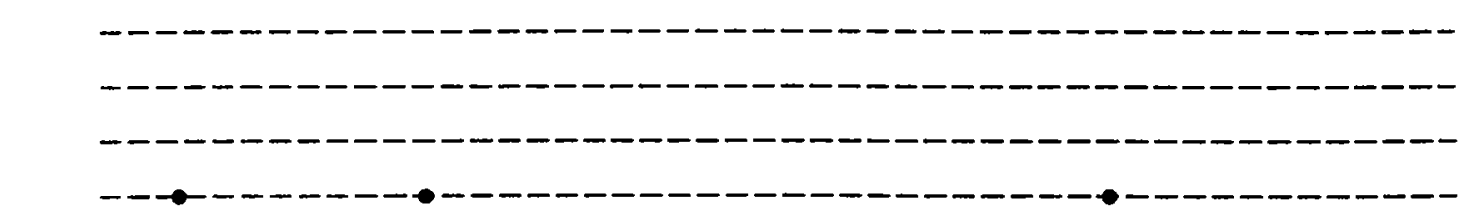

310
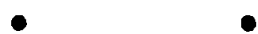

-

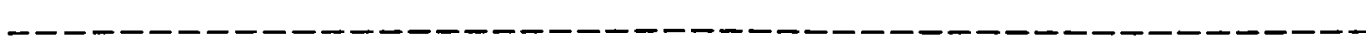

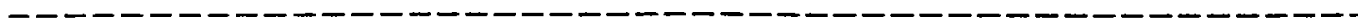

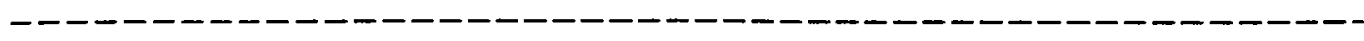

300

B.พA= נI Xec Q1 


\title{
Appendix 5 \\ ALACE Deployments
}

\begin{abstract}
ALACE (Autonomous LAgrangian Circulation Explorer) is a freely drifting body that has been ballasted to be neutrally buoyant at a depth of about 400 meters. Periodically it pumps oil from an internal bladder to an external bladder, changing its displacement and causing it to rise to the surface. Any data taken during the previous dive is then relayed to shore using the ARGOS satellite system. Estimates of the average current experienced by the buoy while submerged are computed from ARGOS fixes of the buoy's positions at the start and end of a dive. The. buoy remains at the surface transmitting for one day. After retracting the external bladder, it sinks back to its resting depth. Between 50 and 100 dive cycles can be repeated before the batteries are exhausted.
\end{abstract}

The ALACE's deployed during Oc-250 were of two different types. 'Ten instruments were deployed which measured the profile of temperature versus depth with a vertical resolution of about 10 meters and a temperature resolution of .02 degree Celsius. These ALACEs repeated their dive cycle every 10 days. A prototype of a "CTD" ALACE was also deployed during Oc-250. It had improved electronics for measuring pressure and temperature and incorporated an inductive cell to measure water conductivity. The vertical resolution was 5 meters near the surface and increased to 10 meters below about 200 meters. The temperature resolution was several millidegrees Celsius. Conductivity and temperature were processed onboard to estimate salinity. Profiles of temperature, pressure, and salinity were transmitted via ARGOS every 14 days. Three ALACEs were deployed along a ray extending from the Central mooring to the Northeast mooring. The other eight instruments were deployed along the ship's track from the Northeast mooring to the Northwest mooring. Table A5-1 details the ALACE units deployed, variables measured, and the time and position of deployment.

Table A5-1

ALACE Deployment Information

Serial No. Data Time of Deployment

Deployed Position Latitude Longitude

\begin{tabular}{|c|c|c|c|}
\hline 46 & $\mathrm{~T}, \mathrm{P}$ & 13 Feb $1319 Z$ & $2727.580 \mathrm{~N} 2706.920^{\prime} \mathrm{W}$ \\
\hline 101 & $\mathrm{~T}, \mathrm{P}$ & 14 Feb $0116 Z$ & 2924.140 'N $2523.931^{\prime} \mathrm{W}$ \\
\hline 98 & $\mathrm{~T}, \mathrm{P}$ & 14 Feb $1328 Z$ & $3124.180^{\prime} \mathrm{N} 2330.533^{\prime} \mathrm{W}$ \\
\hline 100 & $T, P$ & $21 \mathrm{Feb} 0413 Z$ & 3300.642 N $2328.465^{\prime} \mathrm{W}$ \\
\hline 97 & $\mathrm{~T}, \mathrm{P}$ & 21 Feb $1010 Z$ & $3259.368^{\prime} \mathrm{N} 2450.382^{\prime} \mathrm{W}$ \\
\hline 103 & $\mathrm{~T}, \mathrm{P}$ & 21 Feb $1613 Z$ & $3259.396^{\prime} \mathrm{N} 2613.393^{\prime} \mathrm{W}$ \\
\hline 59 & $\mathrm{~T}, \mathrm{P}, \mathrm{C}$ & 21 Feb $1615 Z$ & 3259.396 'N 2613.393 V \\
\hline 102 & $\mathrm{~T}, \mathrm{P}$ & 21 Feb $2211 Z$ & $3259.5466^{\prime} \mathrm{N} 2734.365^{\prime} \mathrm{W}$ \\
\hline 99 & $\mathrm{~T}, \mathrm{P}$ & 22 Feb $0411 \mathrm{Z}$ & 58.331 N 2853.129 ' \\
\hline 44 & $\mathrm{~T}, \mathrm{P}$ & 22 Feb $1207 Z$ & $3257.350^{\prime} \mathrm{N} 3038.513^{\prime}$ \\
\hline 96 & $\mathrm{~T}, \mathrm{P}$ & 22 Feb $2006 Z$ & $3256.675^{\prime} \mathrm{N} \quad 3225.669^{\prime} \mathrm{V}$ \\
\hline
\end{tabular}




\section{Appendix 6 \\ XBT Data}

Three hundred and twelve XBTs were deployed during Oc-250. The T-7 probes were purchased from Sparton of Canada Ltd. The XBT data was logged on a NEC APC IV which had a Spartan data acquisition microprocessor card installed. The digital data was simultaneously logged in memory and plotted on the screen.

Figure A6-1 (a through dd) shows the XBT profiles in groups of ten. Table A6-1 contains the positions and time of the XBTs. Figure A6-2a shows the ship track where the hourly XBTs were dropped. Figure A6-2b through A6-2d are contour plots of XBT temperatures at the surface, 200 meters depth, and 500 meters depth respectively. Figure A6-3 details the location of the XBT sections that appear in Figures A6-4a and A6-4b.

Numbering of XBTs jumps from 223 to 234. 
Figure A6-1a. Overplot of XBT Profiles 1-9

Successive Profiles are offset by $1^{\circ} \mathrm{C}$.

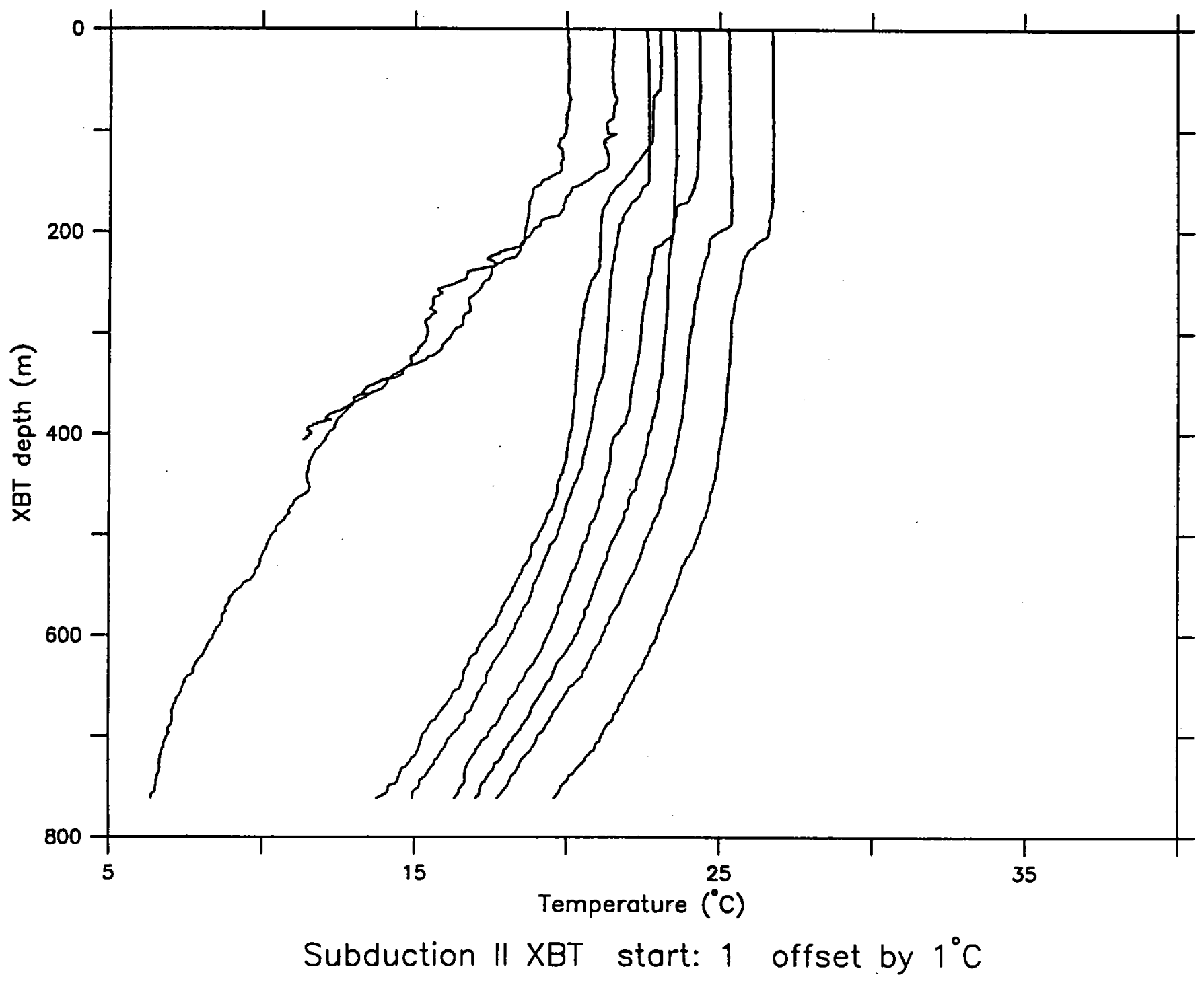


Figure A6-1b. Overplot of XBT Profiles 10-19

Successive Profiles are offset by $1^{0} \mathrm{C}$.

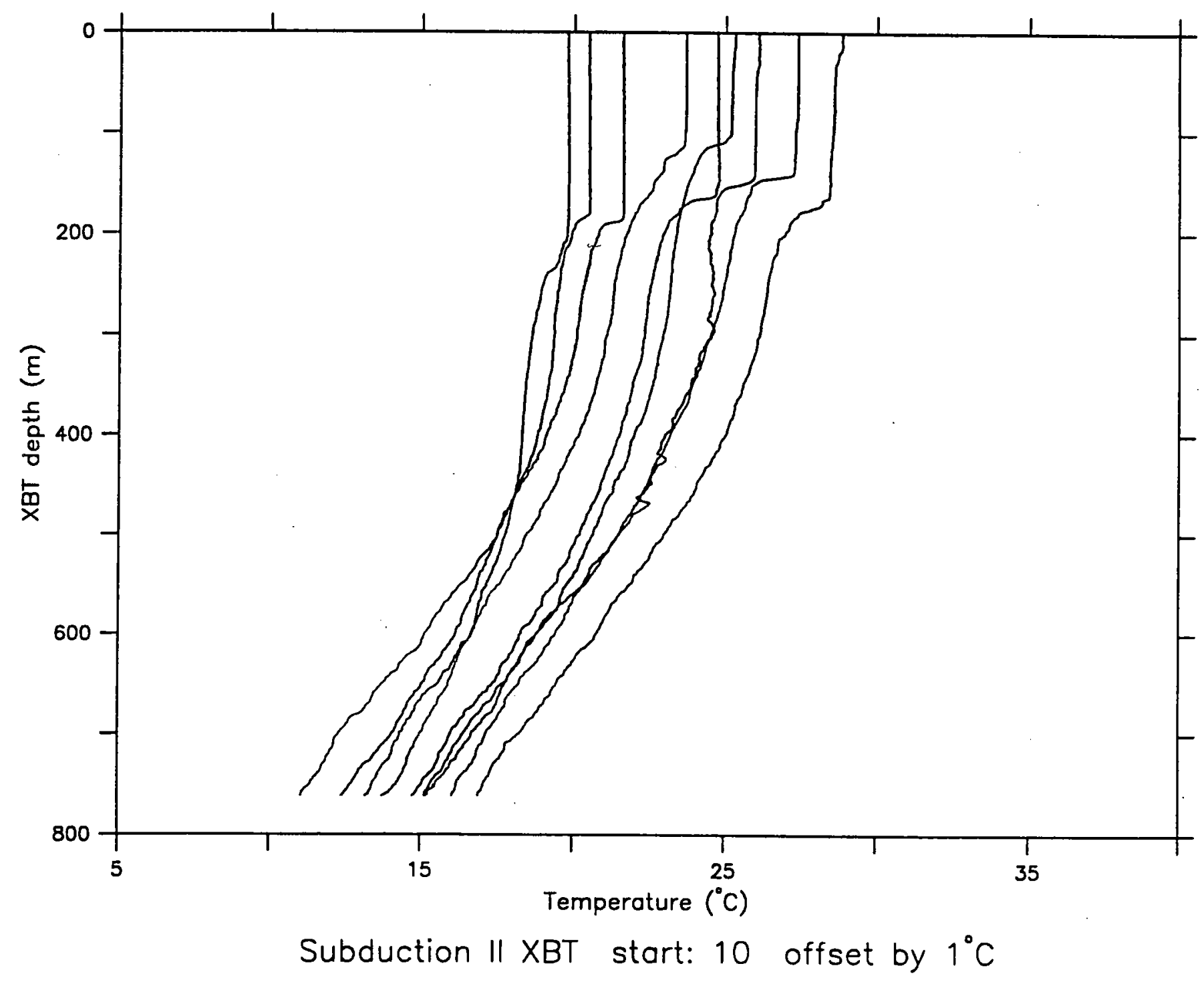


Figure A6-1c. Overplot of XBT Profiles 20-29

Successive Profiles are offset by $1^{\circ} \mathrm{C}$.

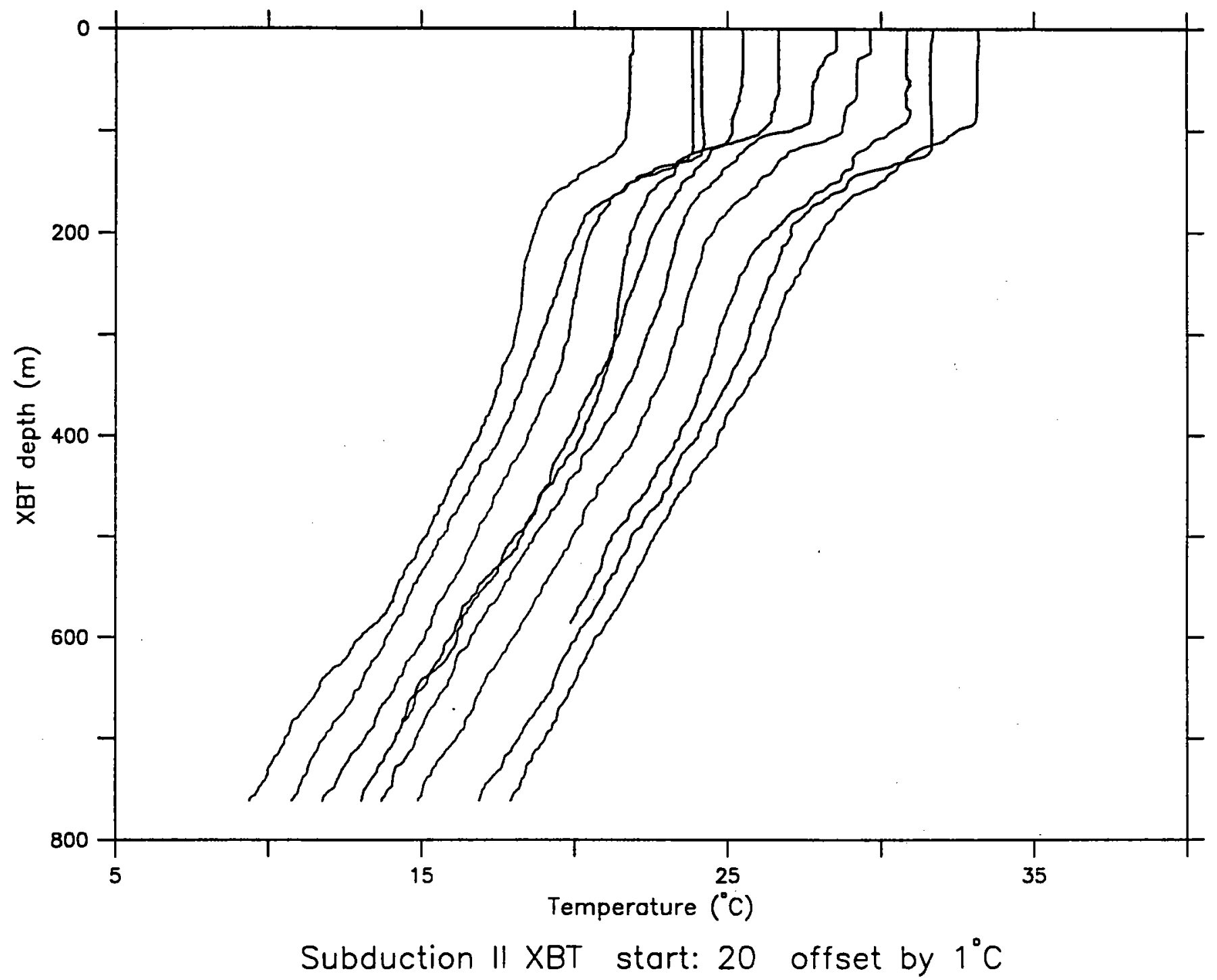


Figure A6-1d. Overplot of XBT Profiles 30-39

Successive Profiles are offset by $1^{0} \mathrm{C}$.

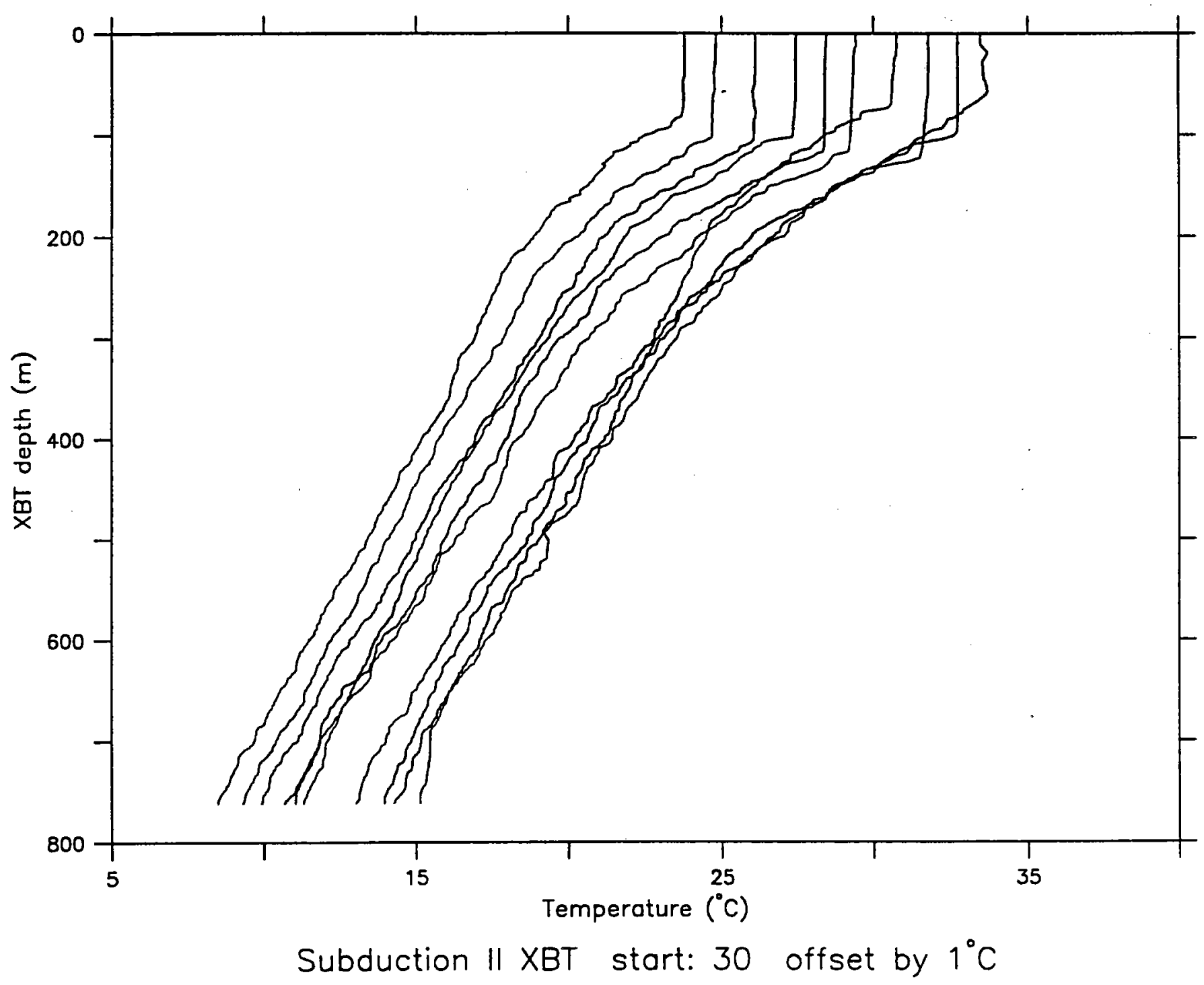


Figure A6-1e. Overplot of XBT Profiles 40-49

Successive Profiles are offset by $1^{\circ} \mathrm{C}$.

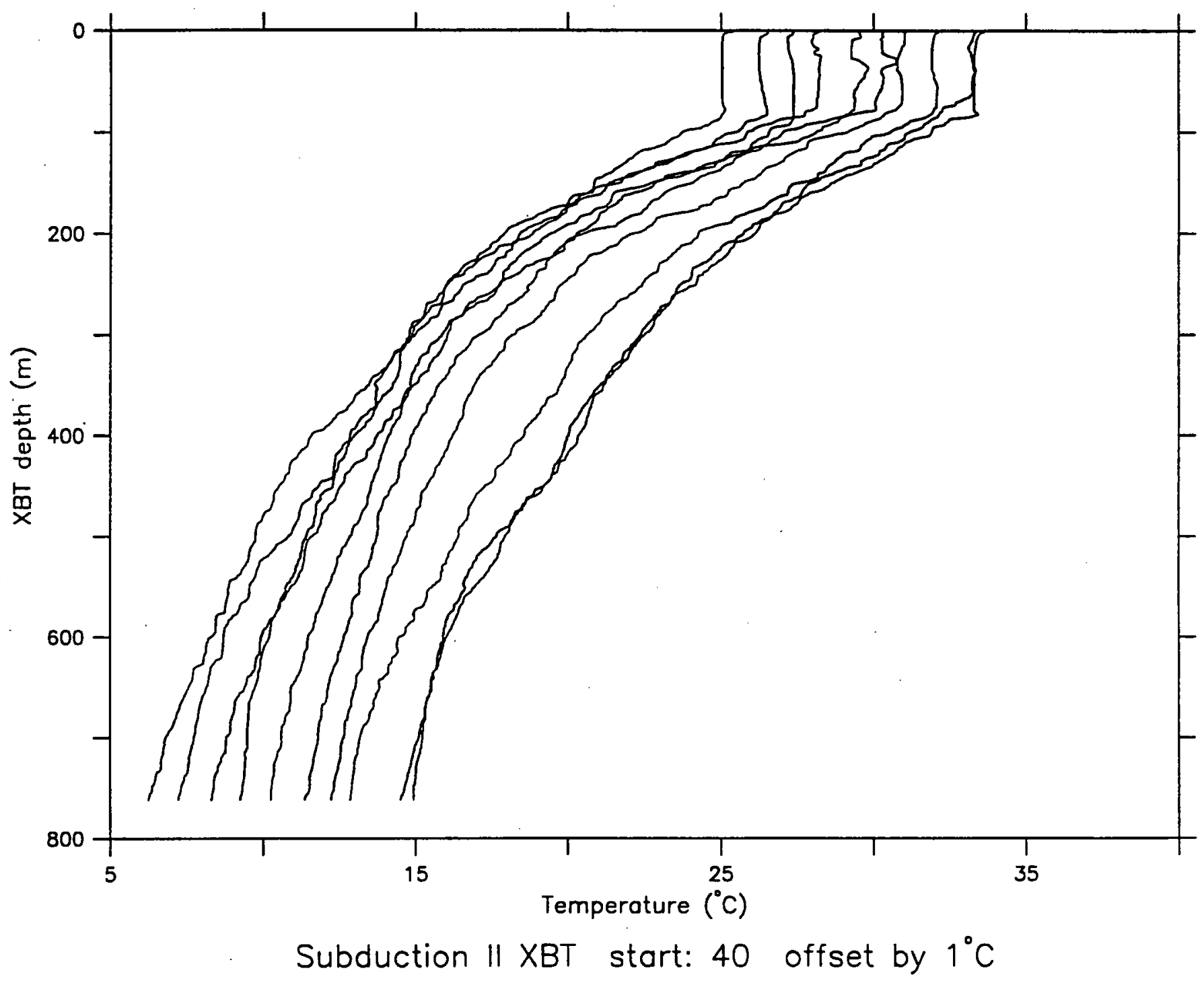


Figure A6-1f. Overplot of XBT Profiles 50-59

Successive Profiles are offset by $1^{\circ} \mathrm{C}$.

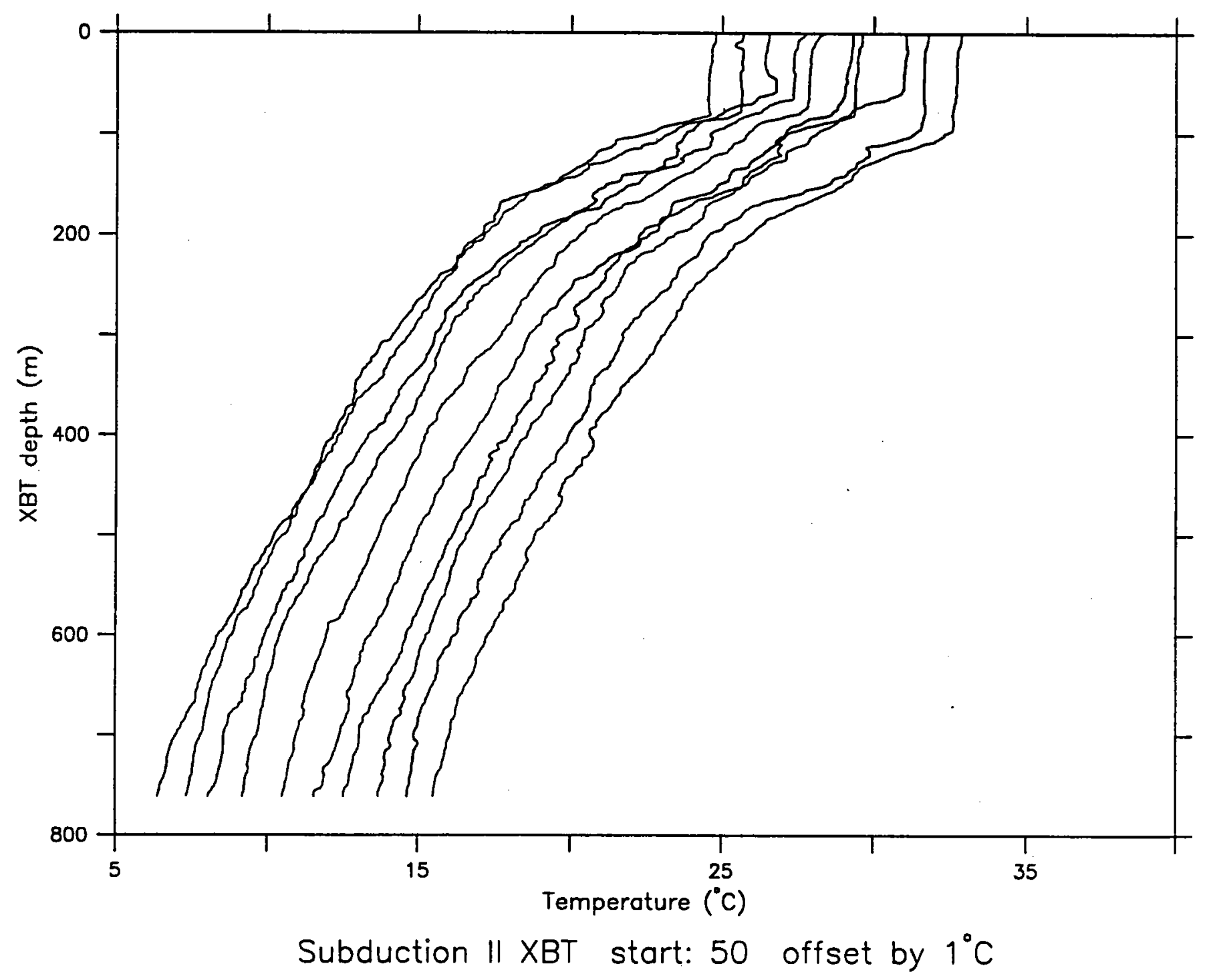


Figure A6-1g. Overplot of XBT Profiles 60-69

Successive Profiles are offset by $1^{\circ} \mathrm{C}$.

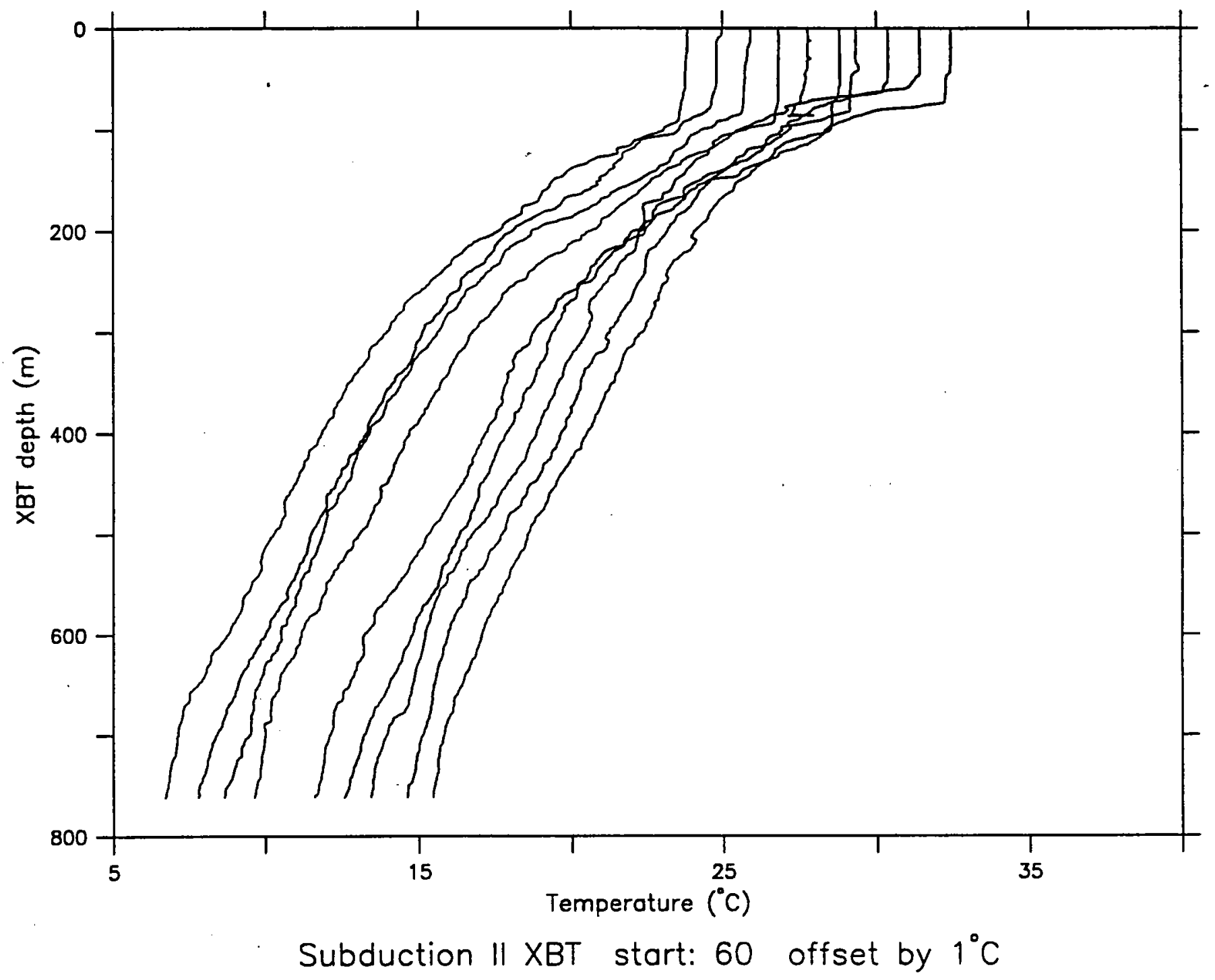


Figure A6-1h. Overplot of XBT Profiles 70-79

Successive Profiles are offset by $1^{\circ} \mathrm{C}$.

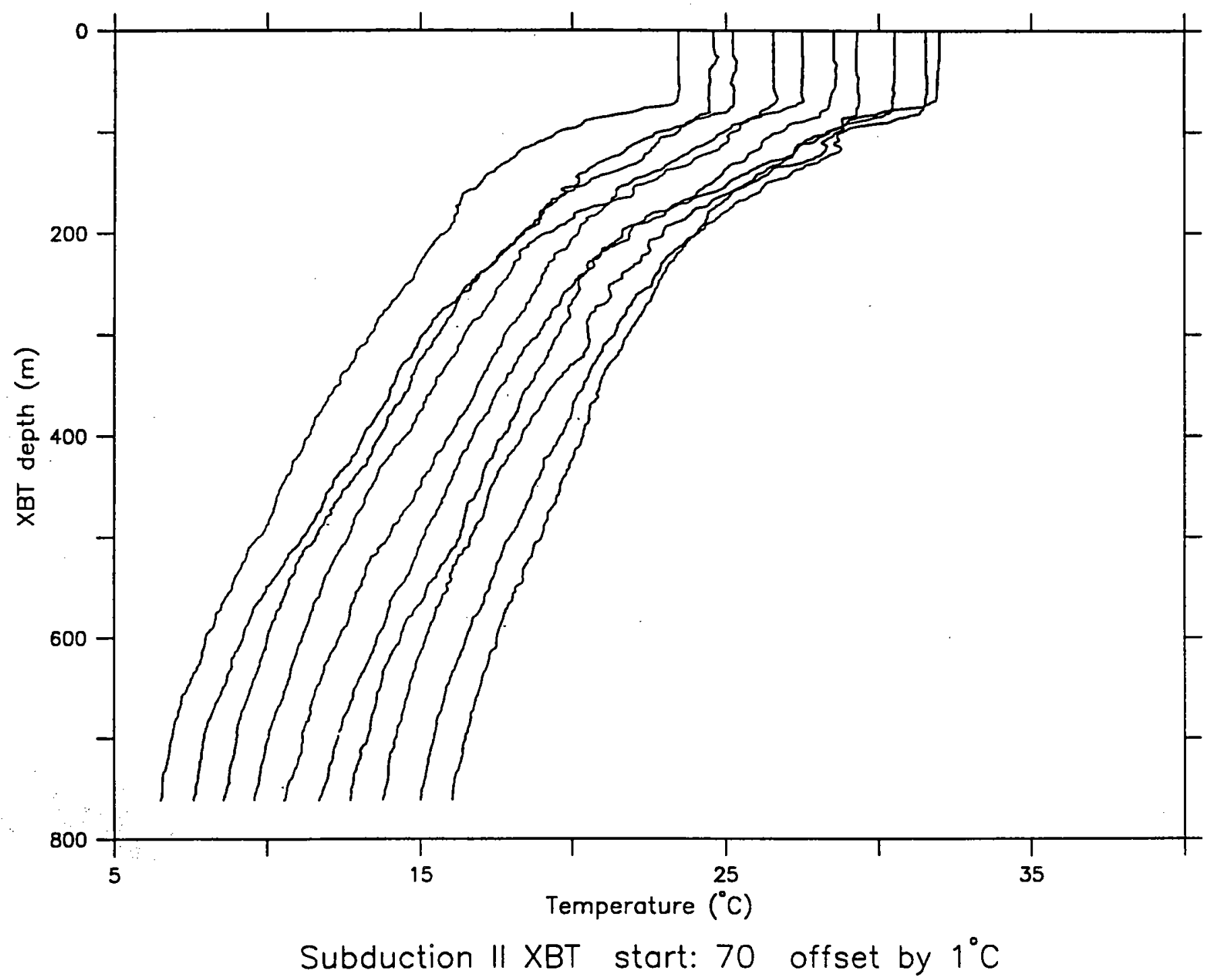


Figure A6-1i. Overplot of XBT Profiles 80-89

Successive Profiles are offset by $1^{\circ} \mathrm{C}$.

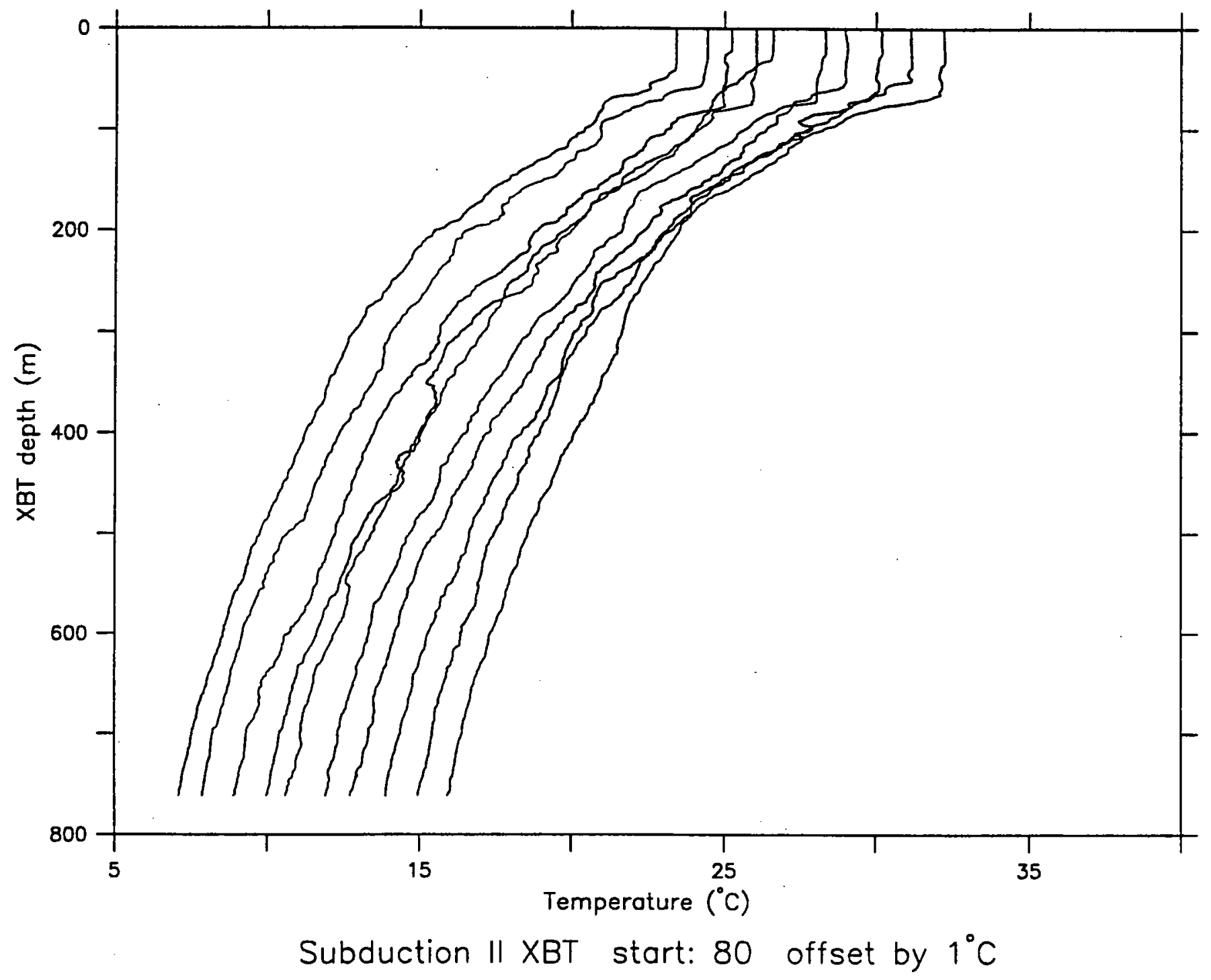


Figure A6-1j. Overplot of XBT Profiles 90-99

Successive Profiles are offset by $1^{0} \mathrm{C}$.

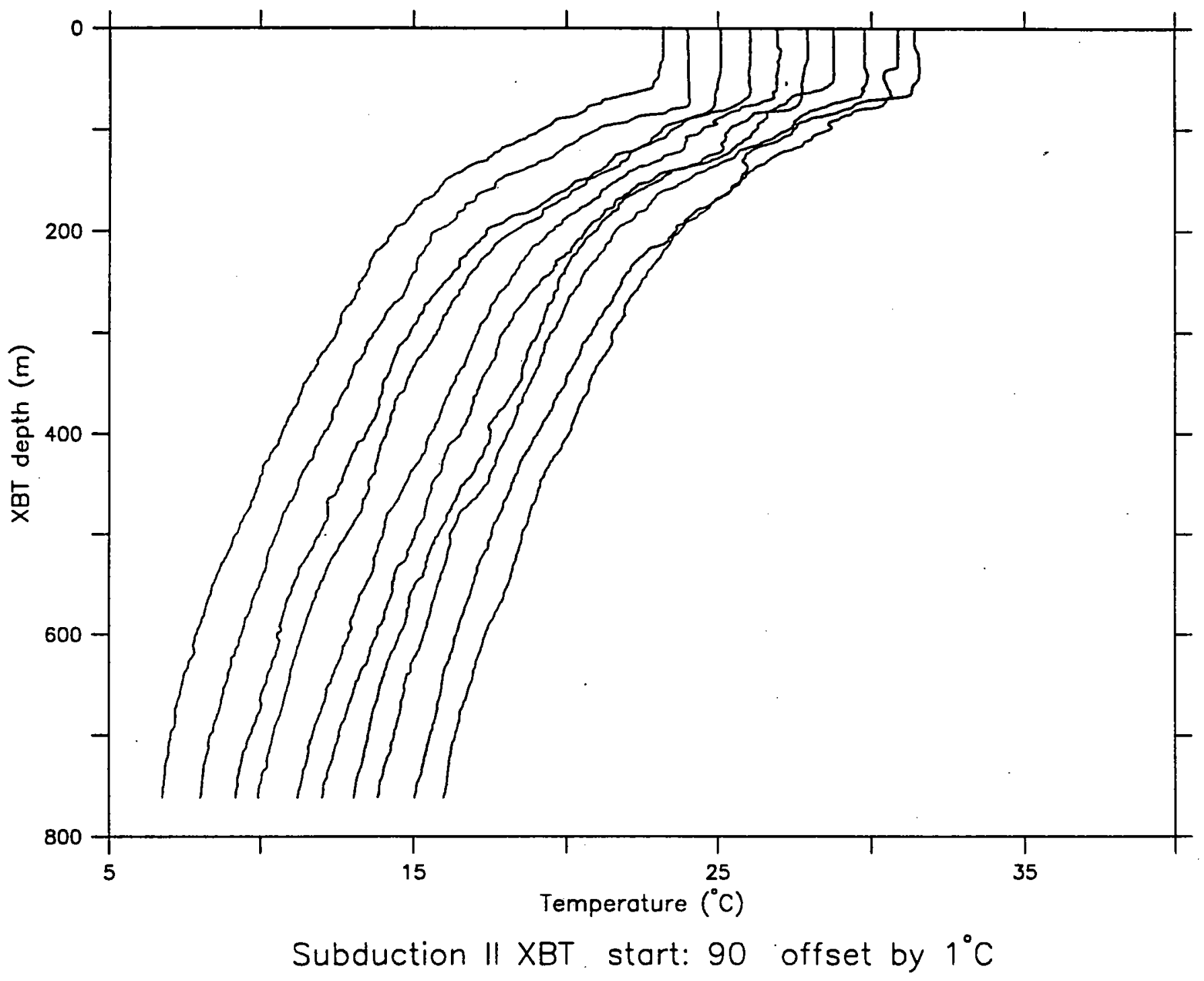


Figure A6-1k. Overplot of XBT Profiles 100-109

Successive Profiles are offset by $1^{\circ} \mathrm{C}$.

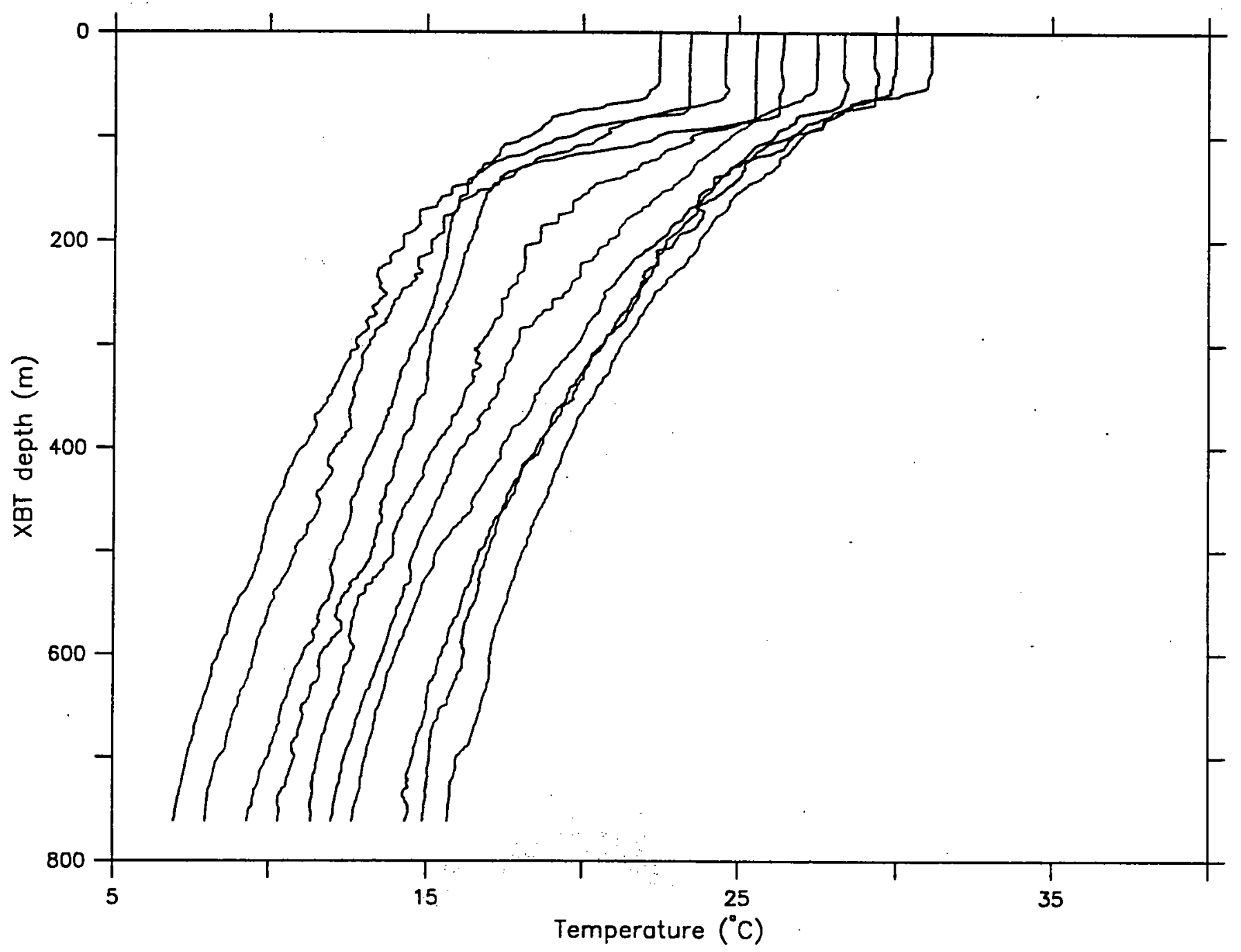

Subduction II XBT start: 100 offset by $1^{\circ} \mathrm{C}$ 
Figure A6-11. Overplot of XBT Profiles 110-119

Successive Profiles are offset by $1^{0} \mathrm{C}$.

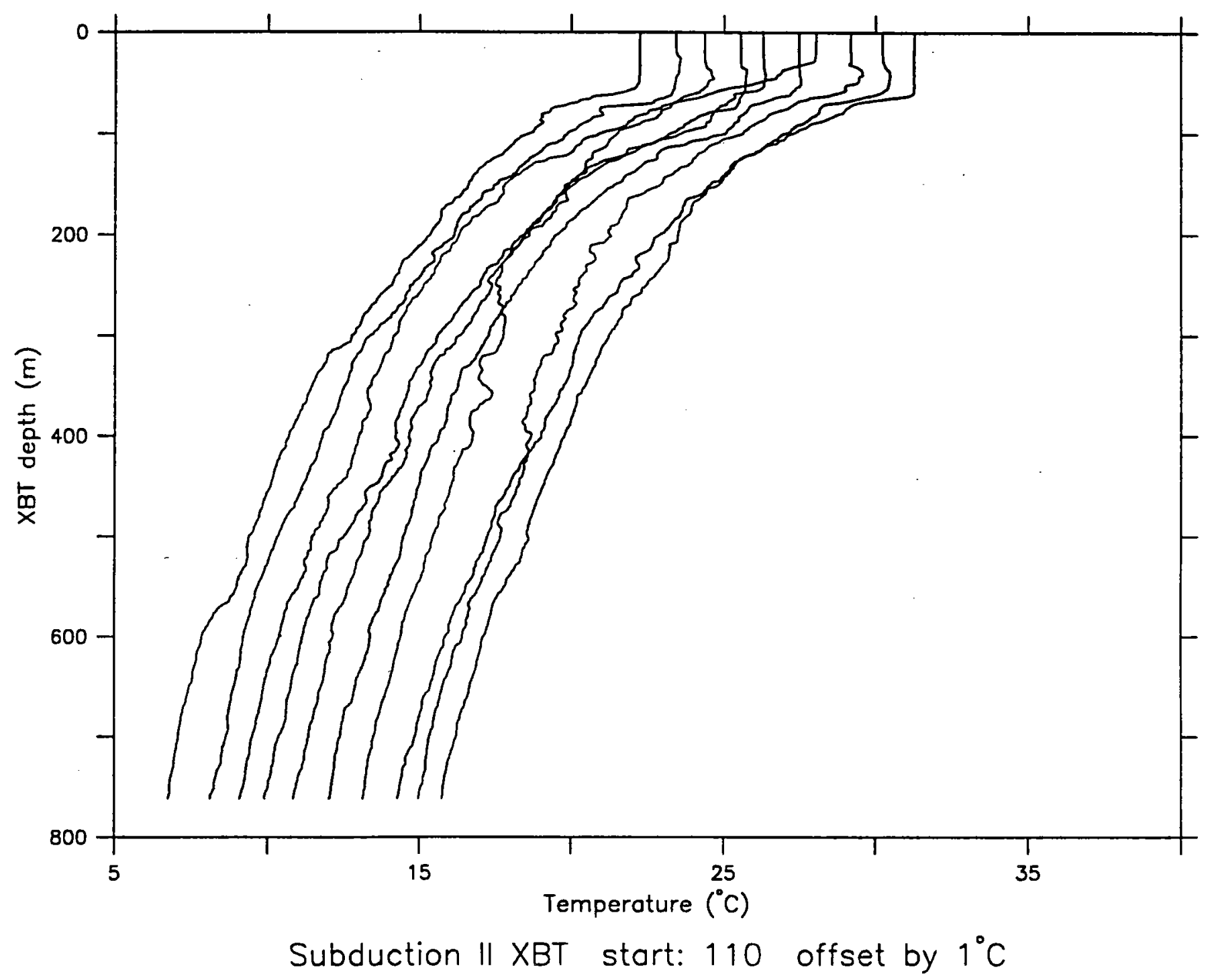


Figure A6-1m. Overplot of XBT Profiles 120-129

Successive Profiles are offset by $1^{\circ} \mathrm{C}$.

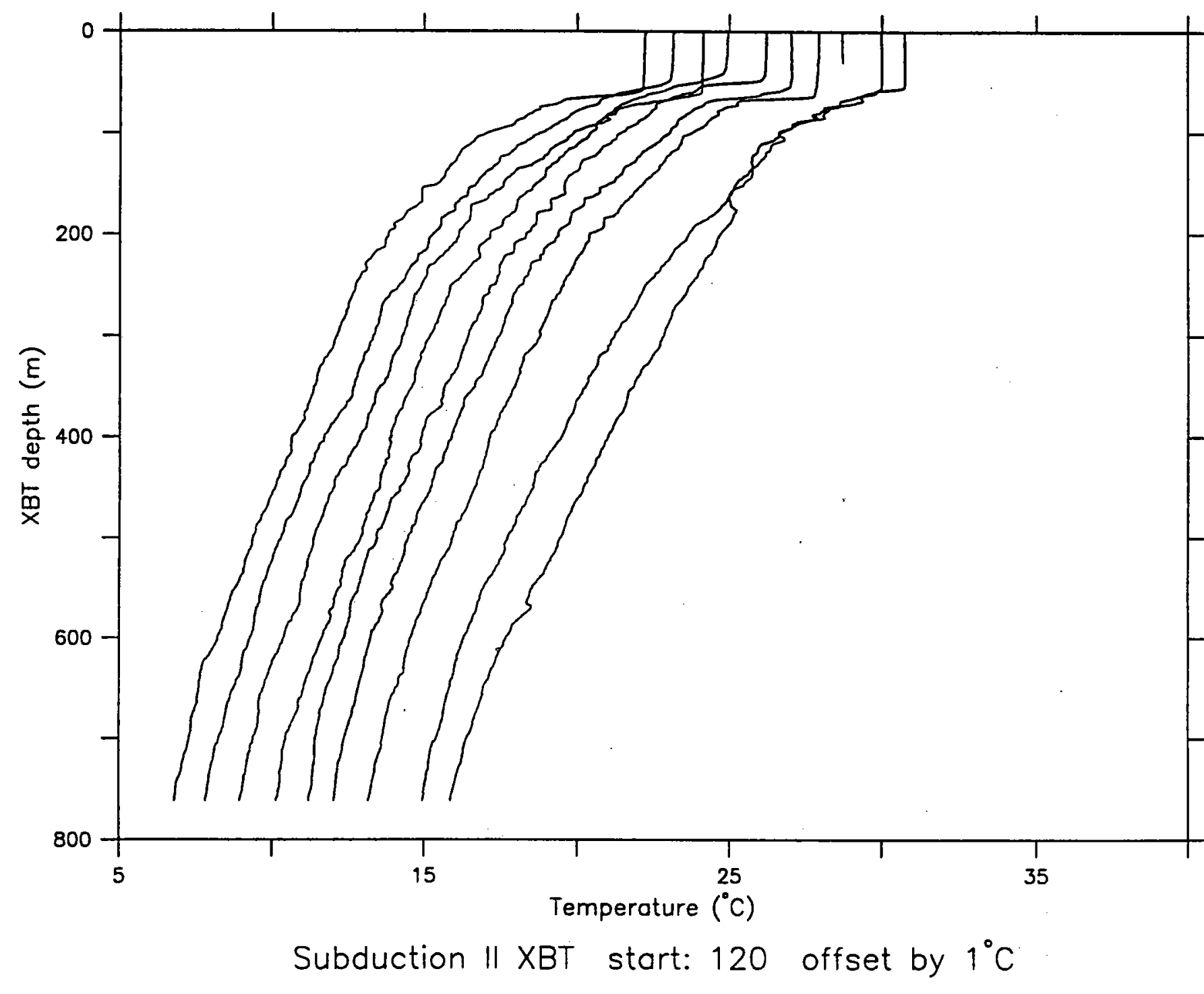


Figure A6-1n. Overplot of XBT Profiles 130-139

Successive Profiles are offset by $1^{0} \mathrm{C}$.

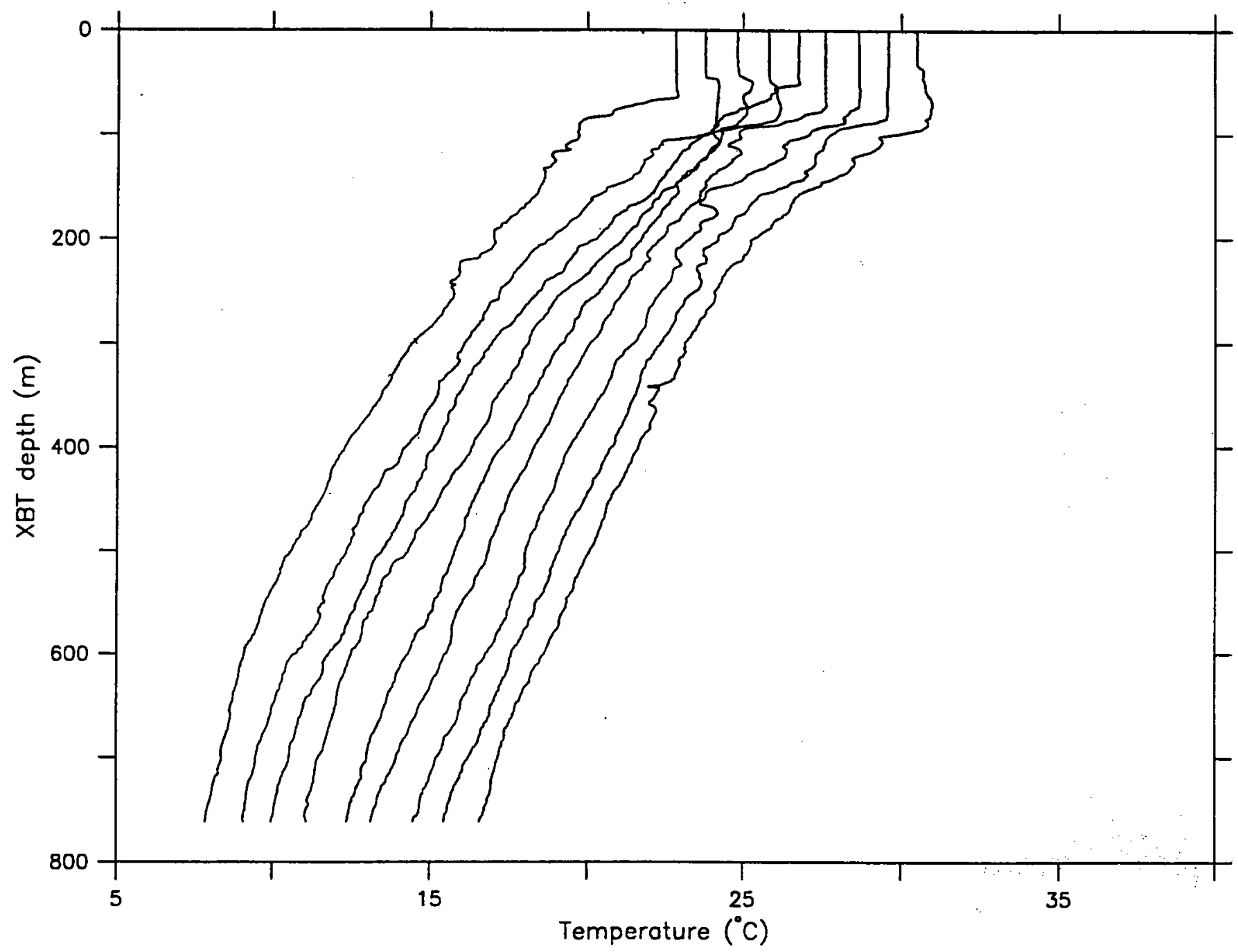

Subduction II XBT start: 130 offset by $1^{\circ} \mathrm{C}$ 
Figure A6-10. Overplot of XBT Profiles 140-149

Successive Profiles are offset by $1^{0} \mathrm{C}$.

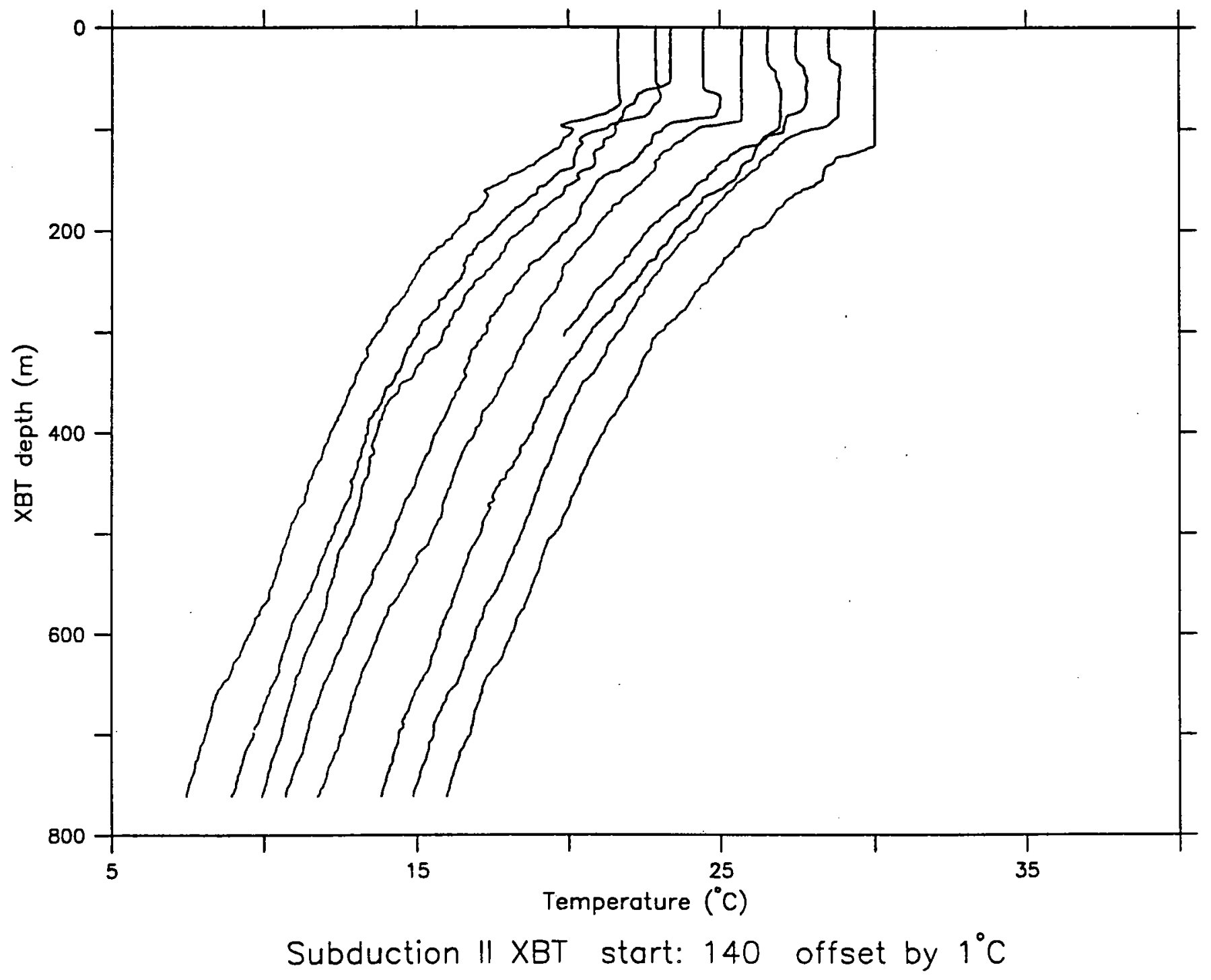


Figure A6-1p. Overplot of XBT Profiles 150-159

Successive Profiles are offset by $1^{\circ} \mathrm{C}$.

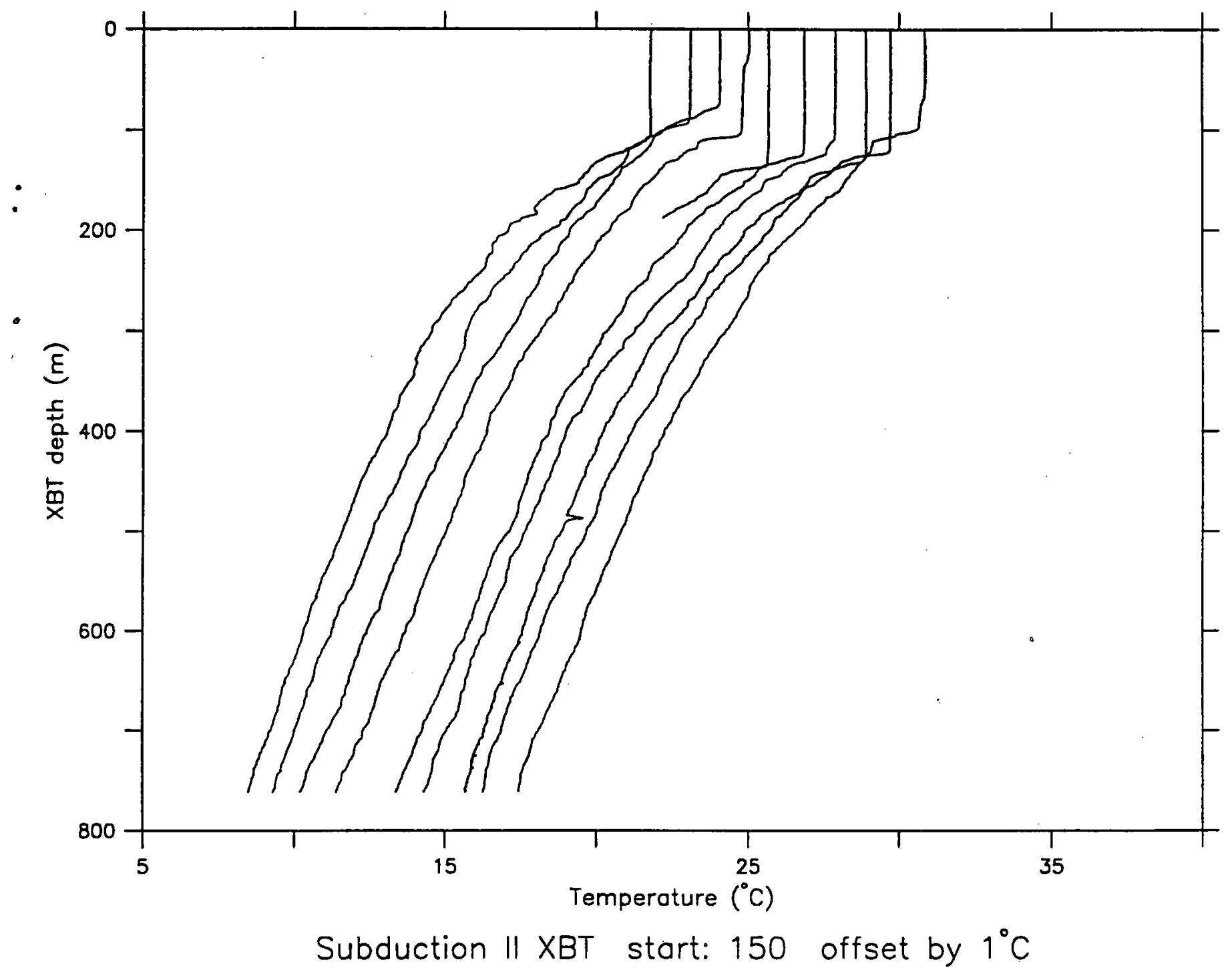


Figure A6-1q. Overplot of XBT Profiles 160-169

Successive Profiles are offset by $1^{0} \mathrm{C}$.

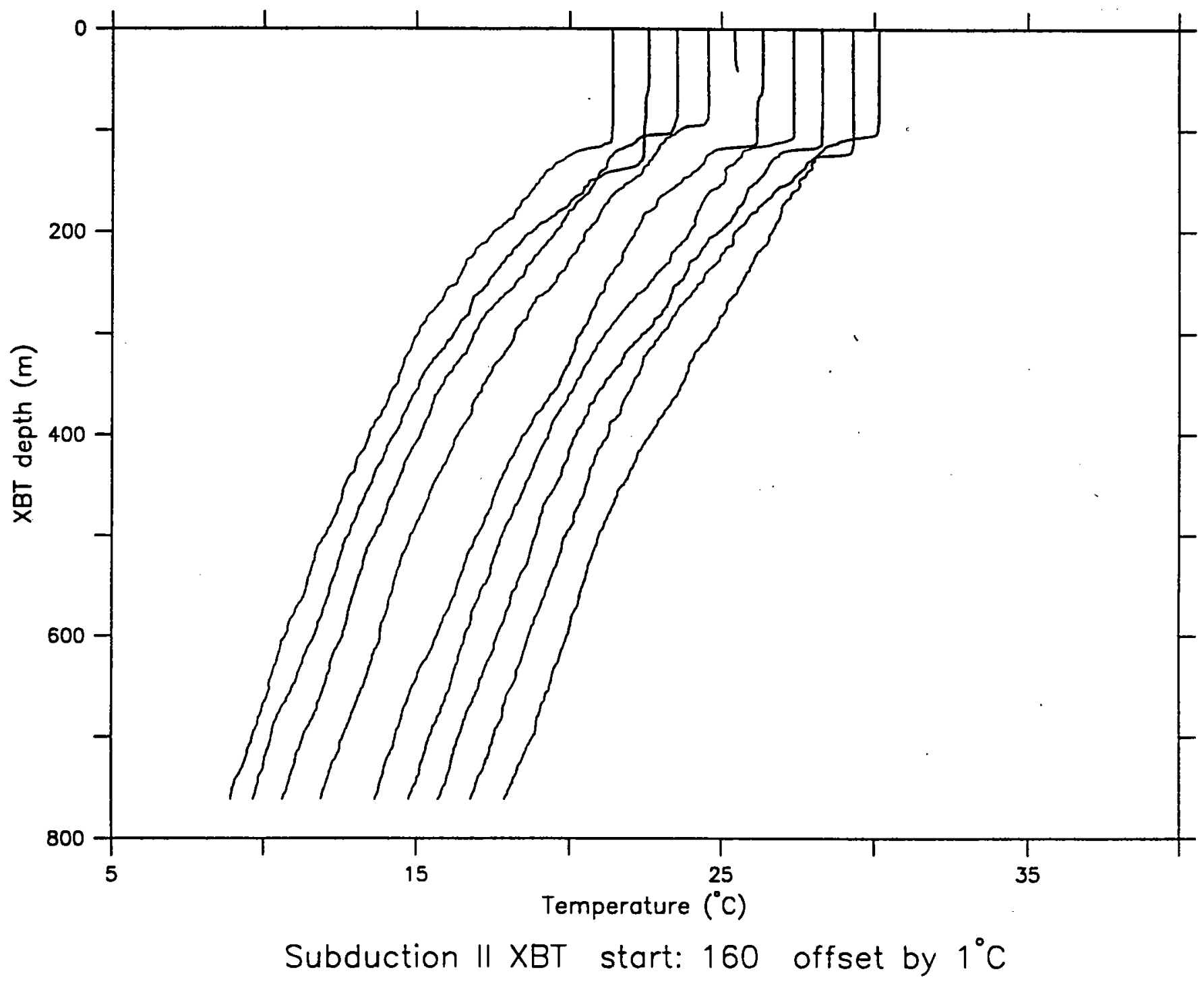


Figure A6-1r. Overplot of XBT Profiles 170-179

Successive Profiles are offset by $1^{\circ} \mathrm{C}$.

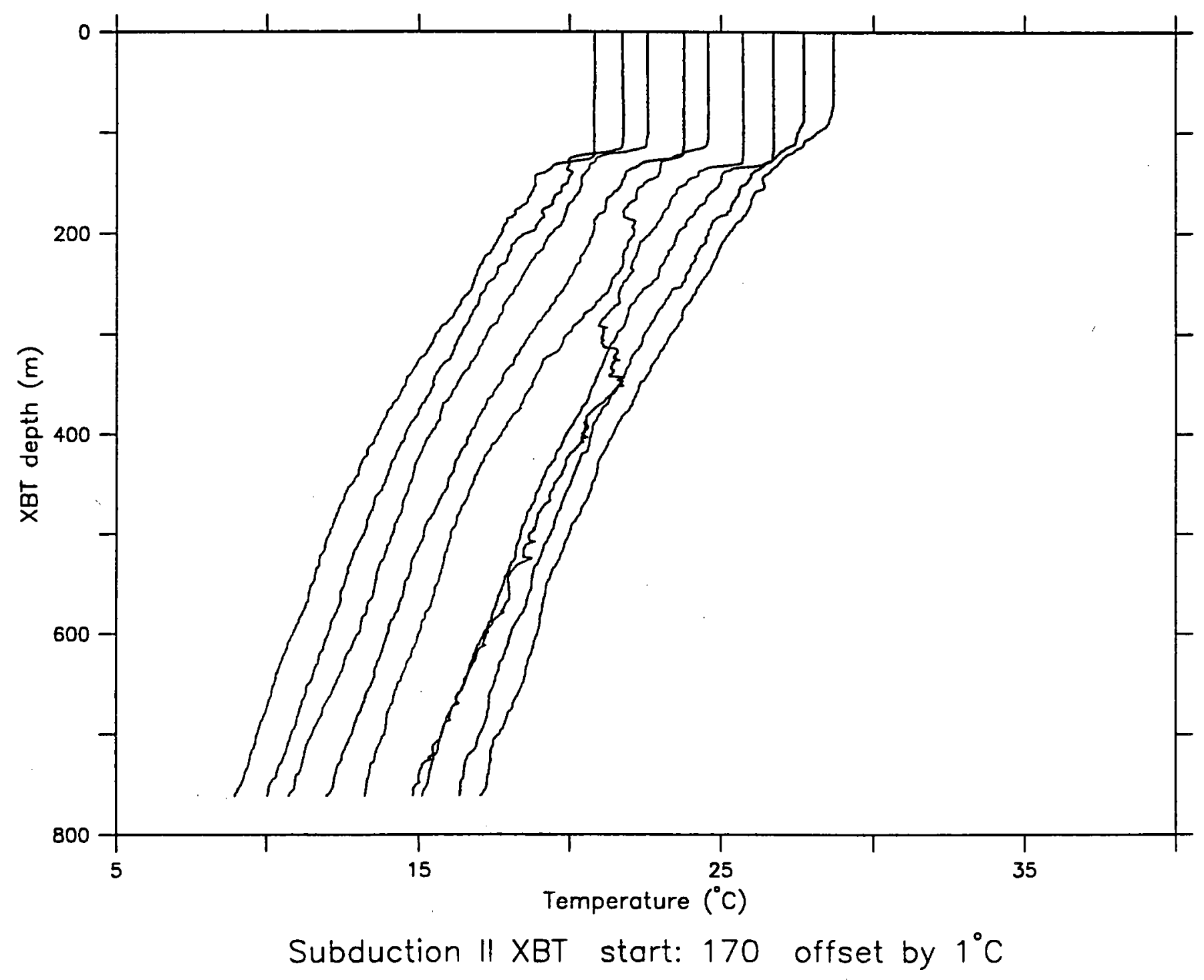


Figure A6-1s. Overplot of XBT Profiles 180-189

Successive Profiles are offset by $1^{\circ} \mathrm{C}$.

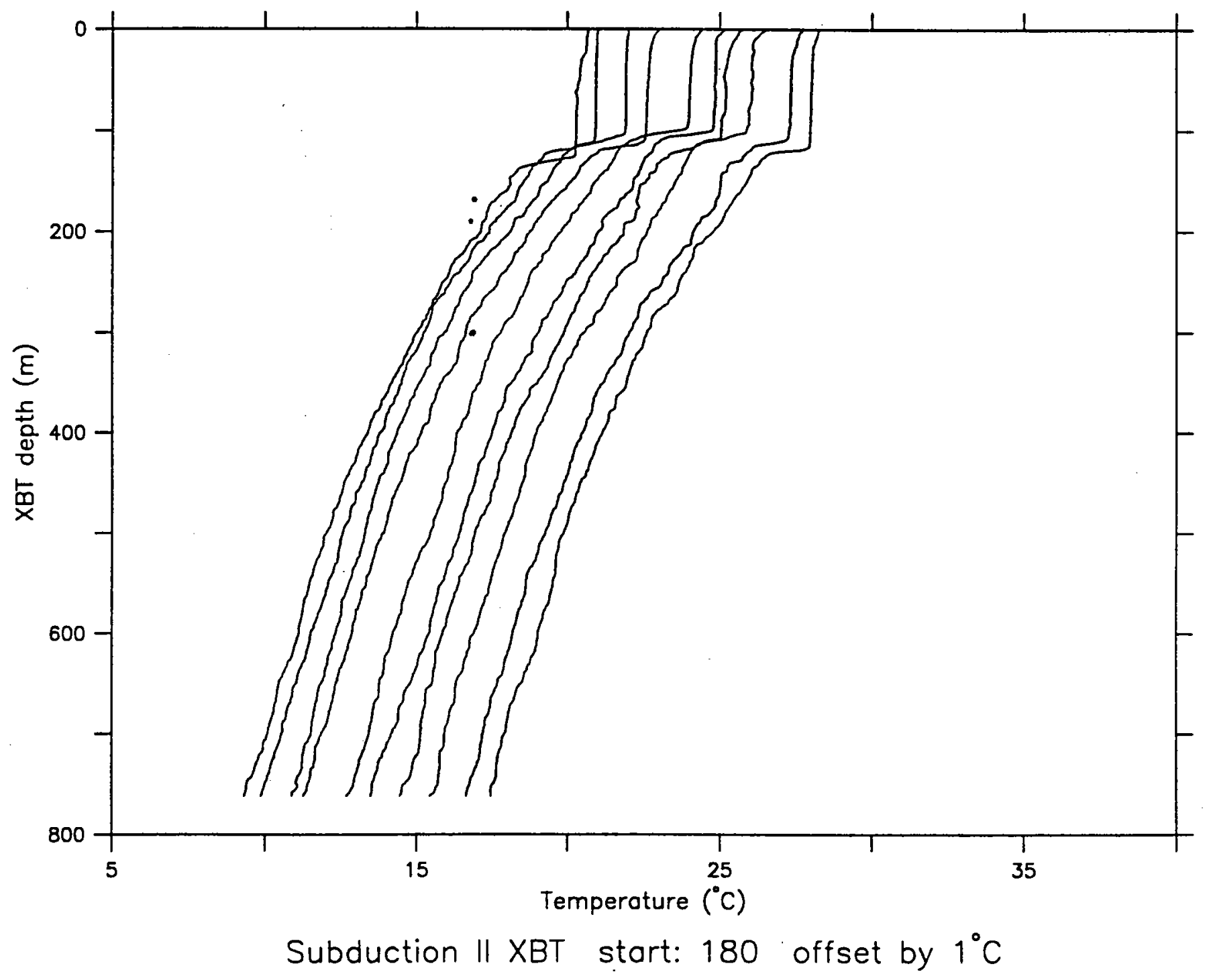


Figure A6-1t. Overplot of XBT Profiles 190-199

Successive Profiles are offset by $1^{\circ} \mathrm{C}$.

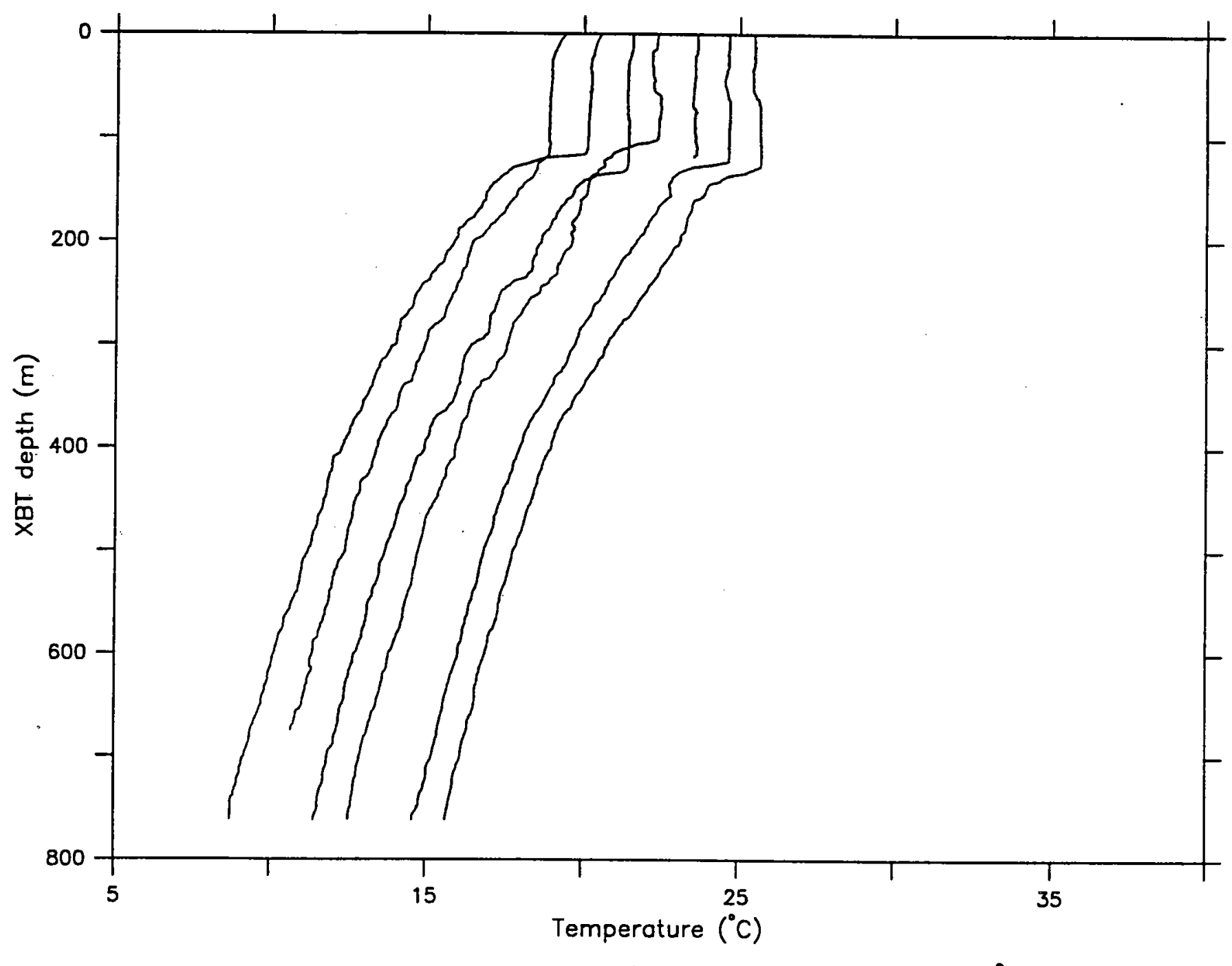

Subduction II XBT start: 190 offset by $1^{\circ} \mathrm{C}$ 
Figure A6-1u. Overplot of XBT Profiles 200-209

Successive Profiles are offset by $1^{0} \mathrm{C}$.

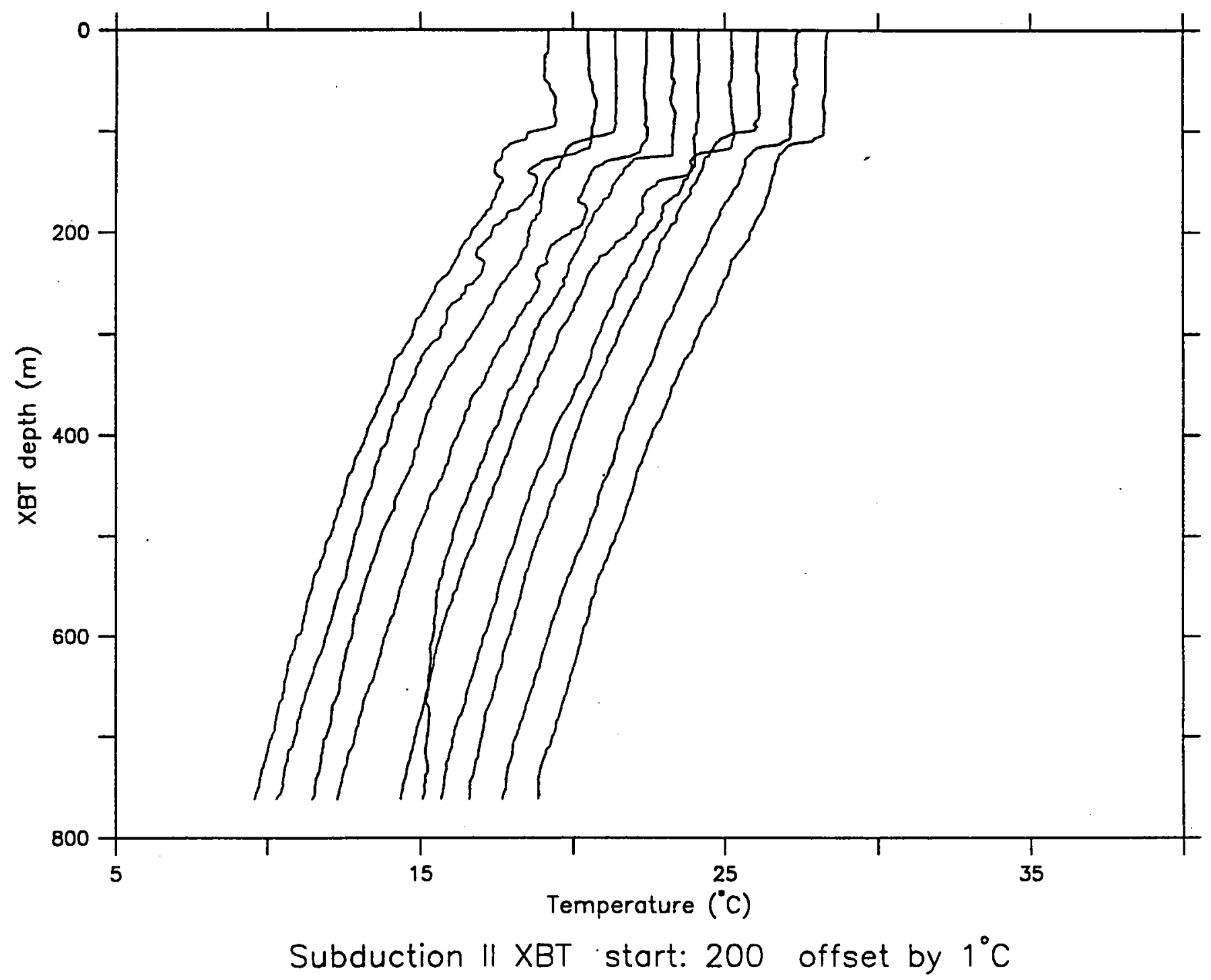


Figure A6-1v. Overplot of XBT Profiles 210-219 Successive Profiles are offset by $1^{0} \mathrm{C}$.

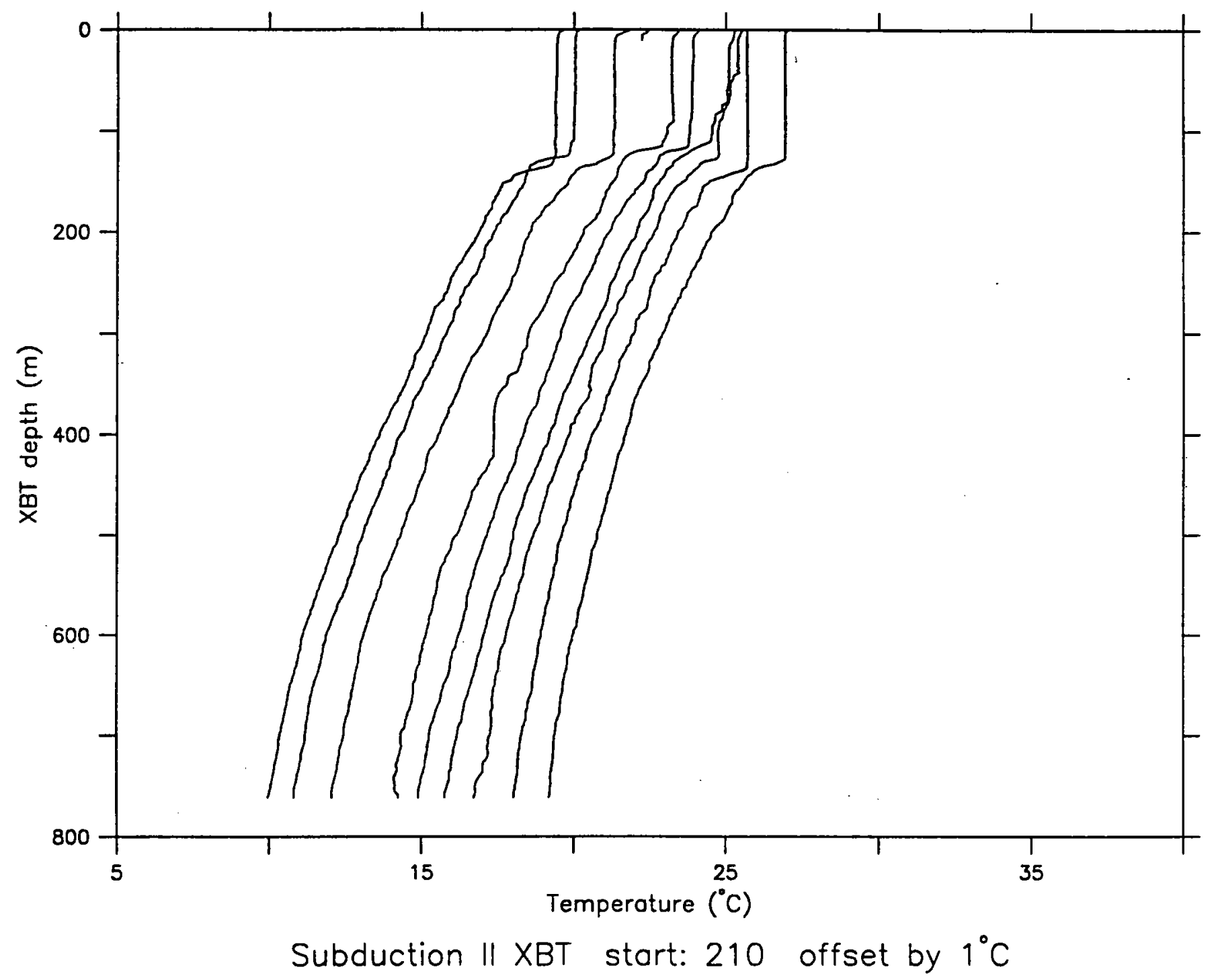


Figure A6-1w. Overplot of XBT Profiles 220-229

Successive Profiles are offset by $1^{0} \mathrm{C}$.

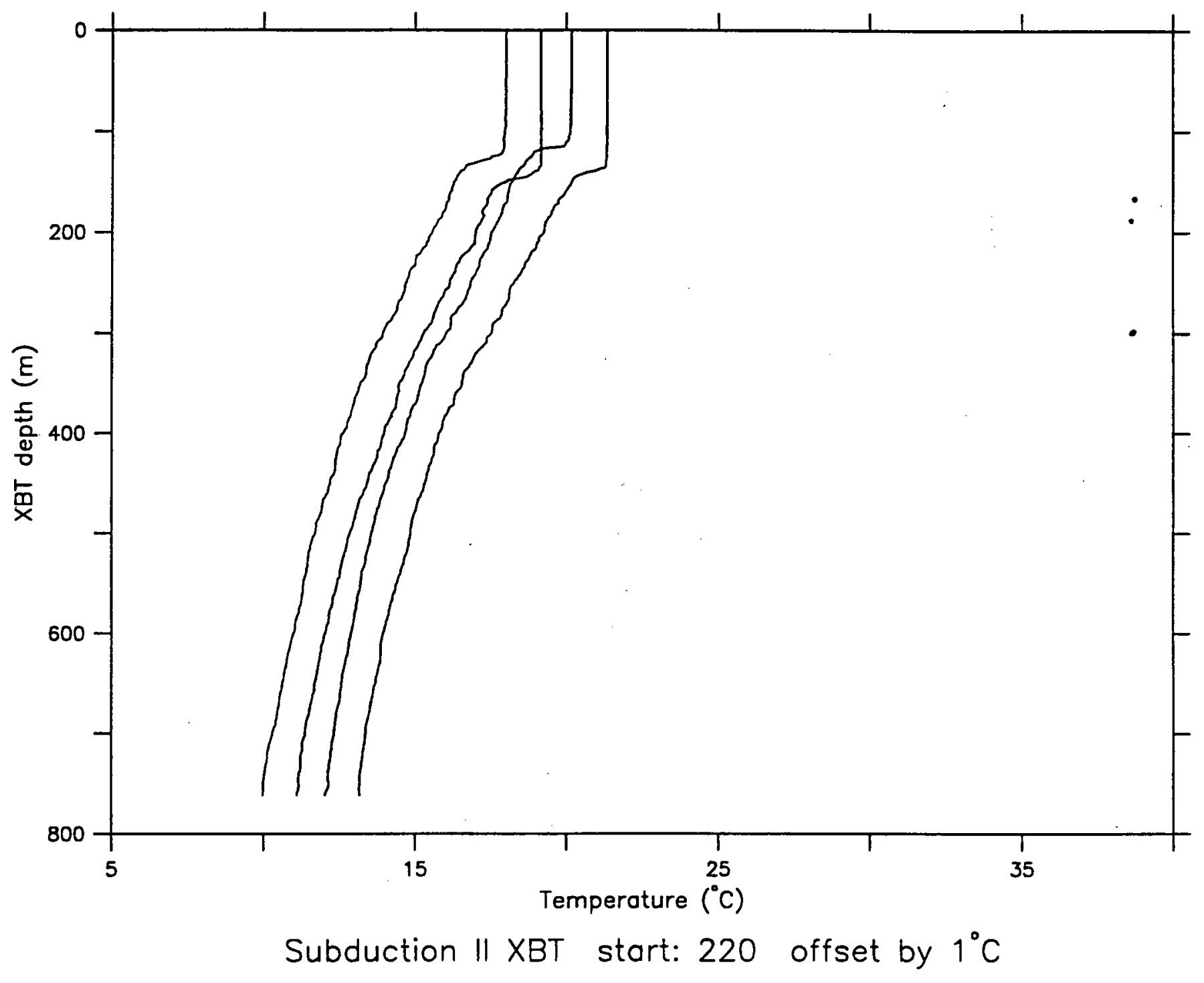


Figure A6-1x. Overplot of XBT Profiles 230-239

Successive Profiles are offset by $1^{0} \mathrm{C}$.

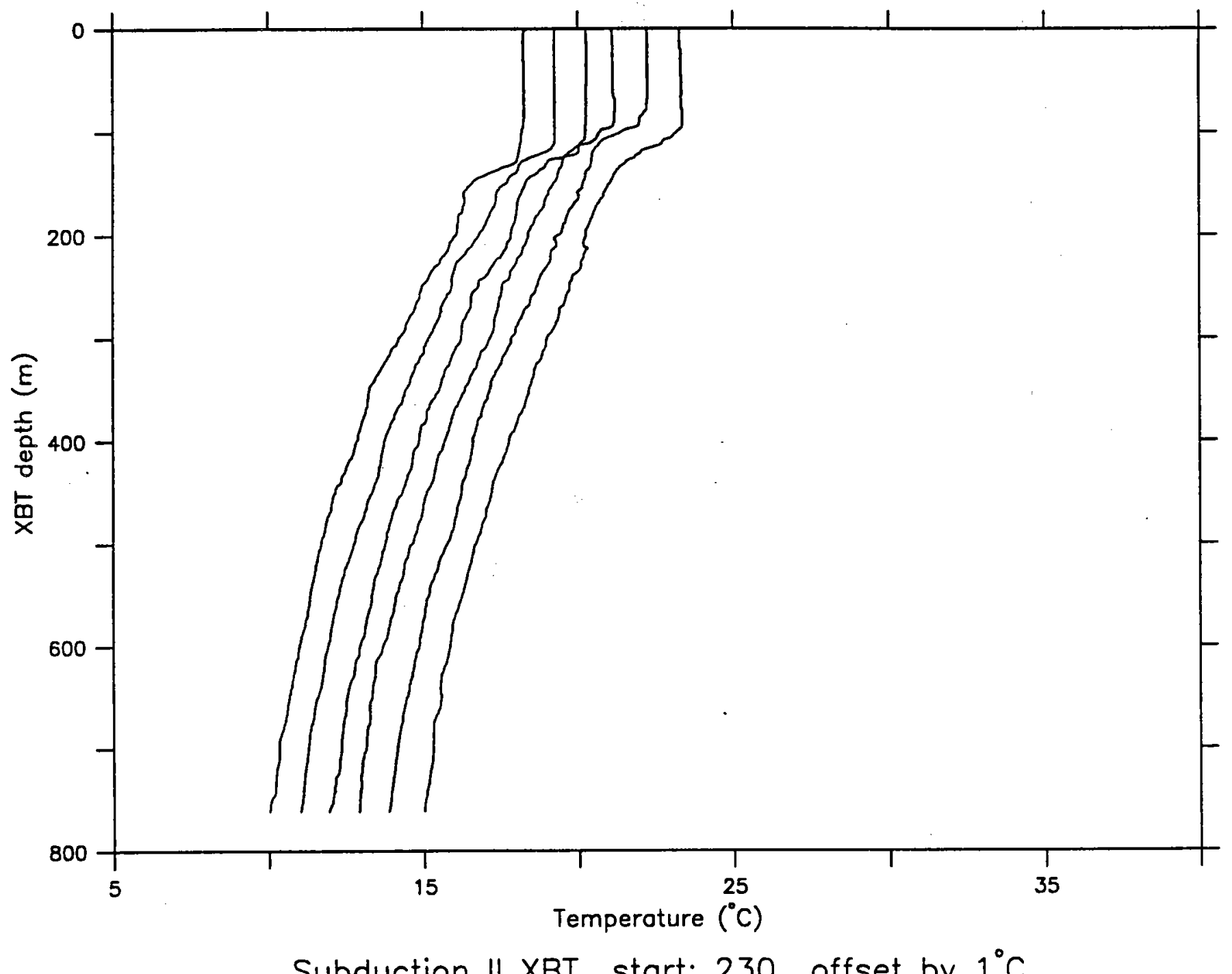

Subduction II XBT start: 230 offset by $1^{\circ} \mathrm{C}$ 
Figure A6-1y. Overplot of XBT Profiles 240-249

Successive Profiles are offset by $1^{0} \mathrm{C}$.

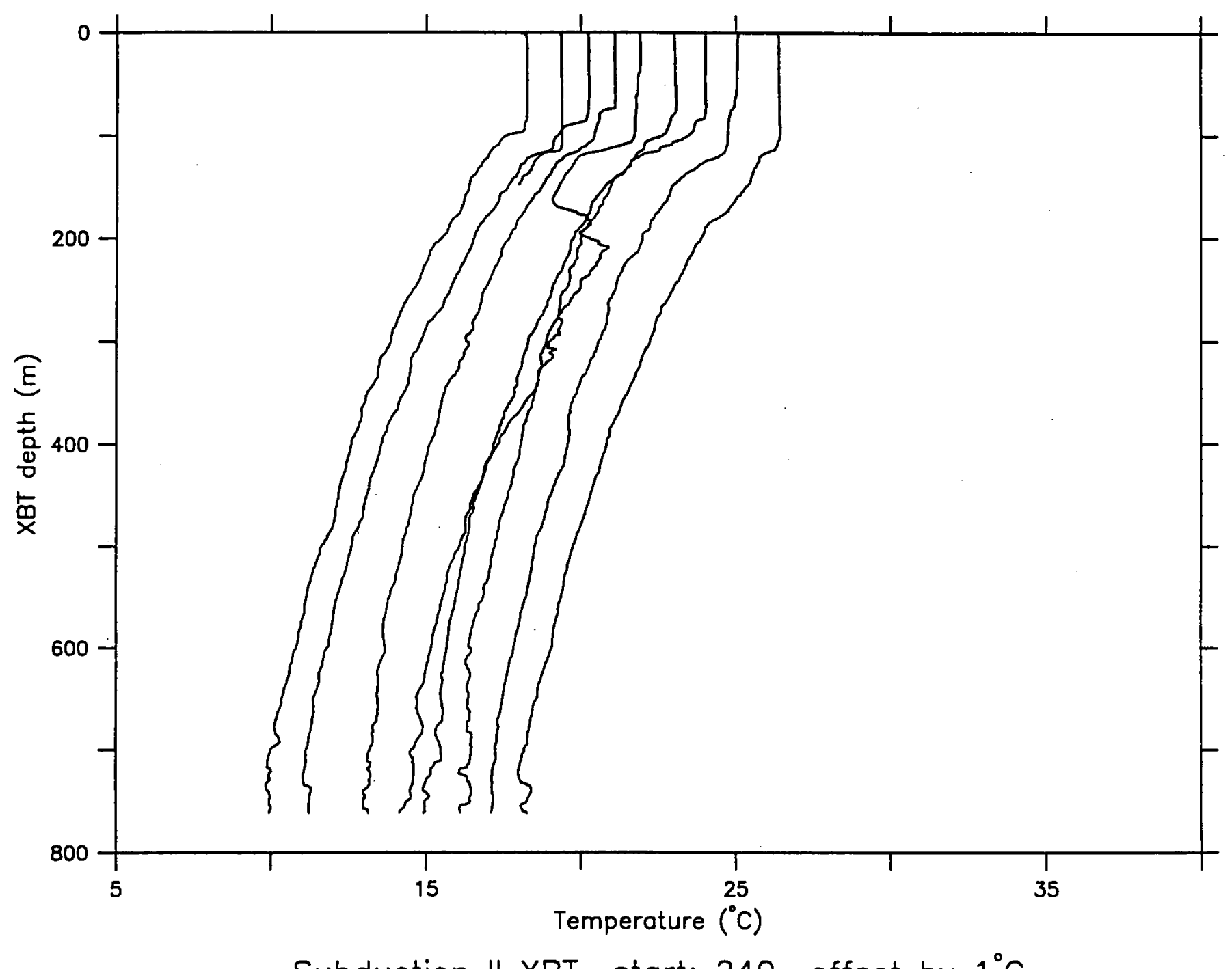

Subduction II XBT start: 240 offset by $1^{\circ} \mathrm{C}$ 
Figure A6-1z. Overplot of XBT Profiles 250-259

Successive Profiles are offset by $1^{0} \mathrm{C}$.

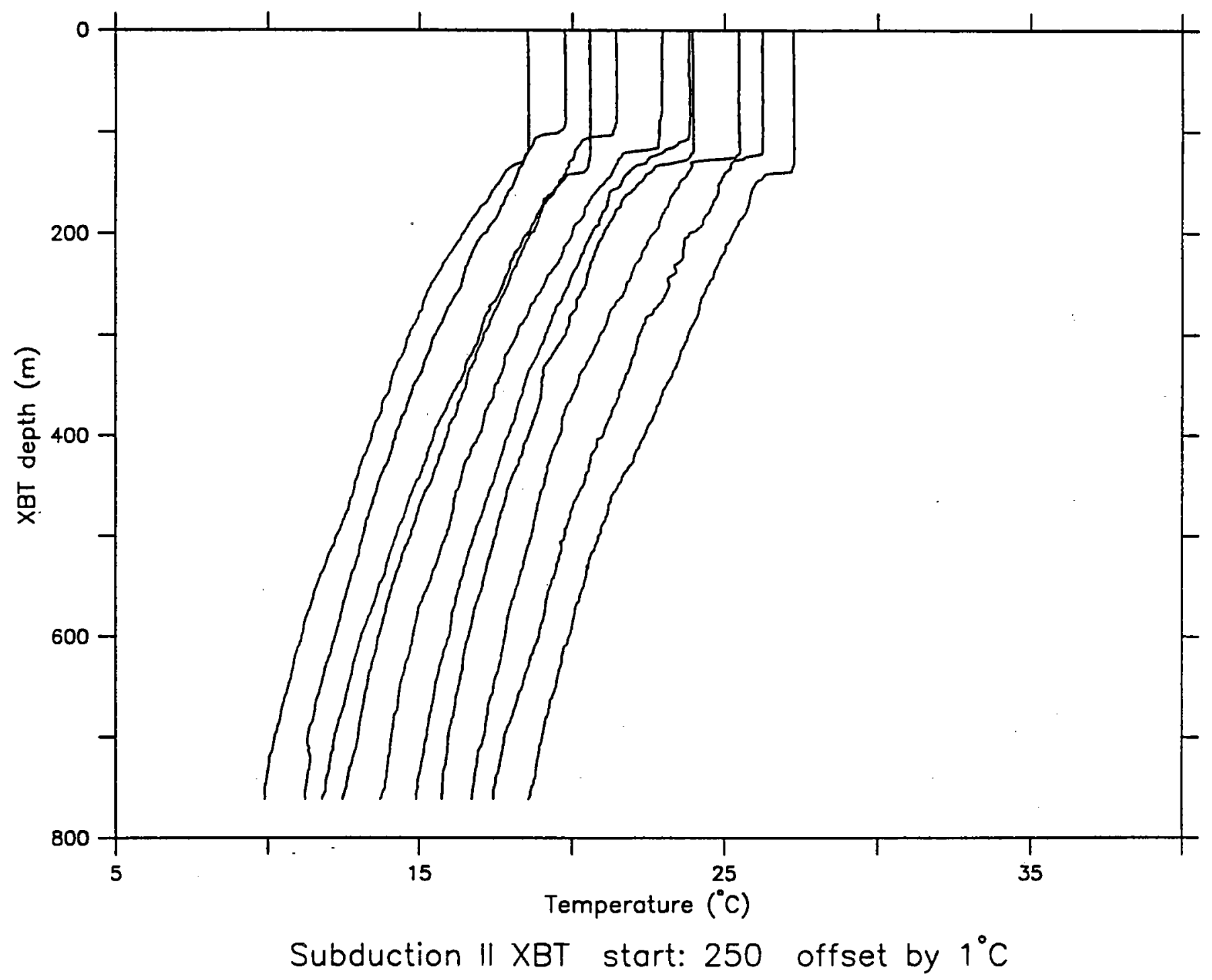


Figure A6-1aa. Overplot of XBT Profiles 260-269

Successive Profiles are offset by $1^{0} \mathrm{C}$.

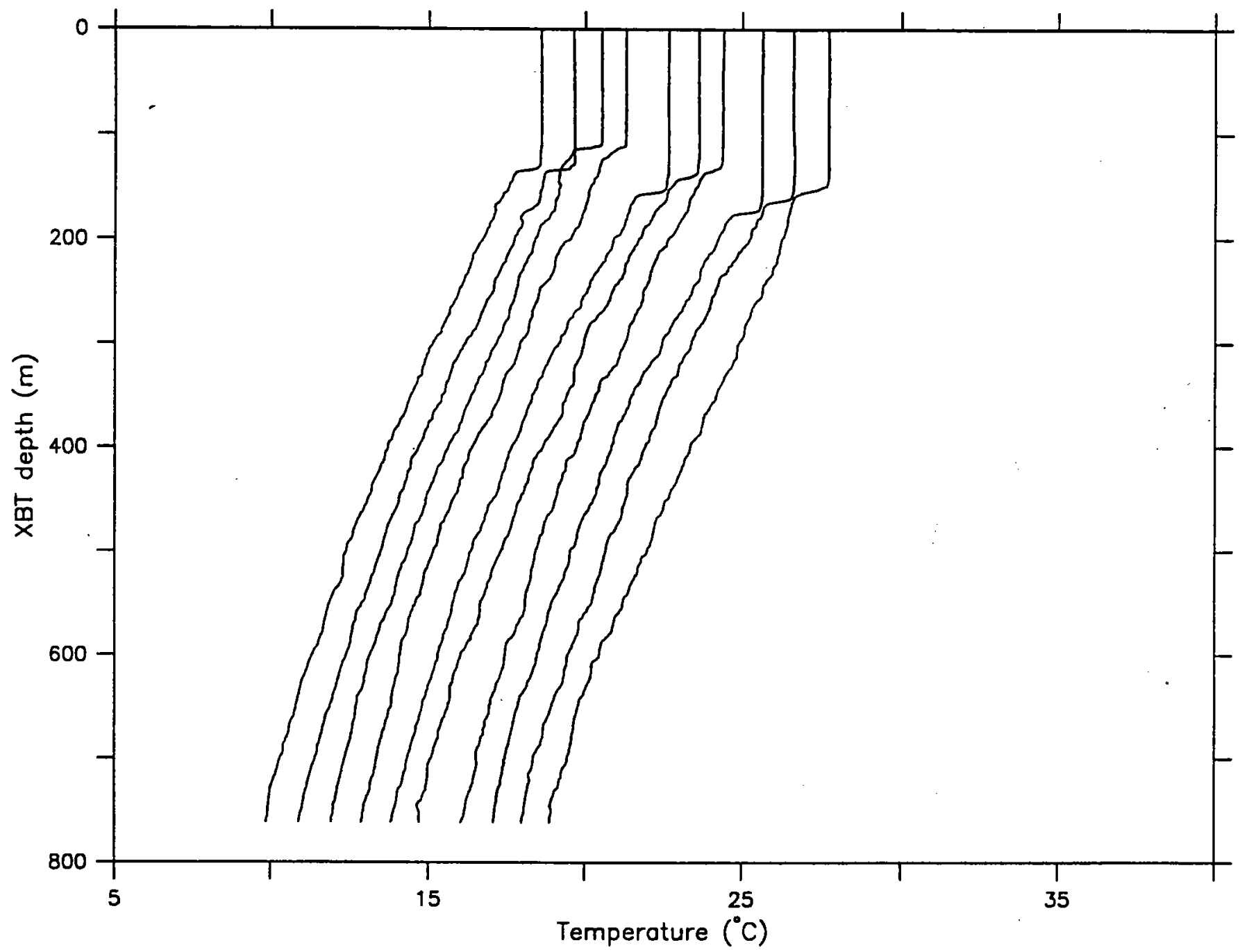

Subduction II XBT start: 260 offset by $1{ }^{\circ} \mathrm{C}$ 
Figure A6-1bb. Overplot of XBT Profiles 270-279

Successive Profiles are offset by $1^{\circ} \mathrm{C}$.

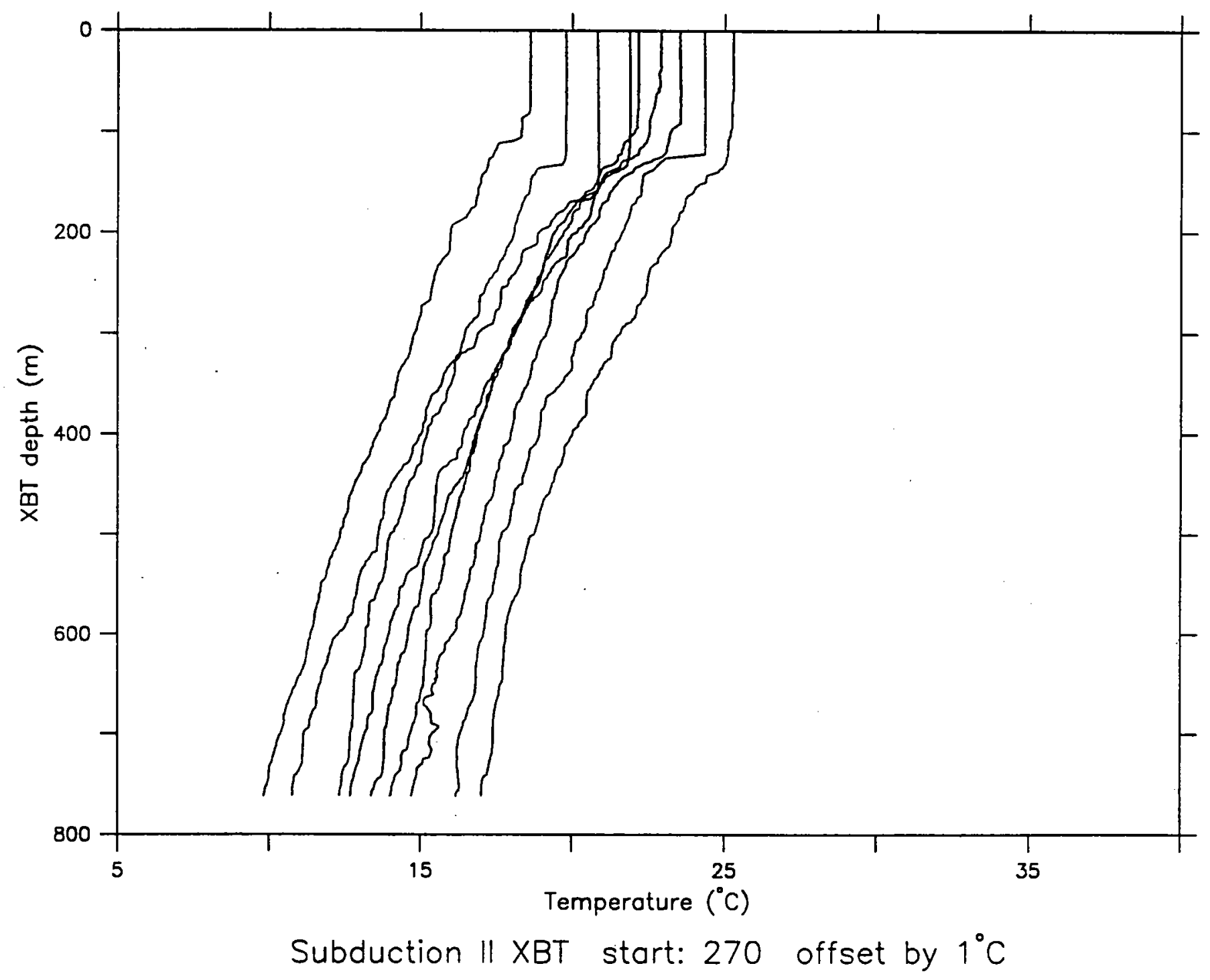


Figure A6-1cc. Overplot of XBT Profiles 280-289

Successive Profiles are offset by $1^{\circ} \mathrm{C}$.

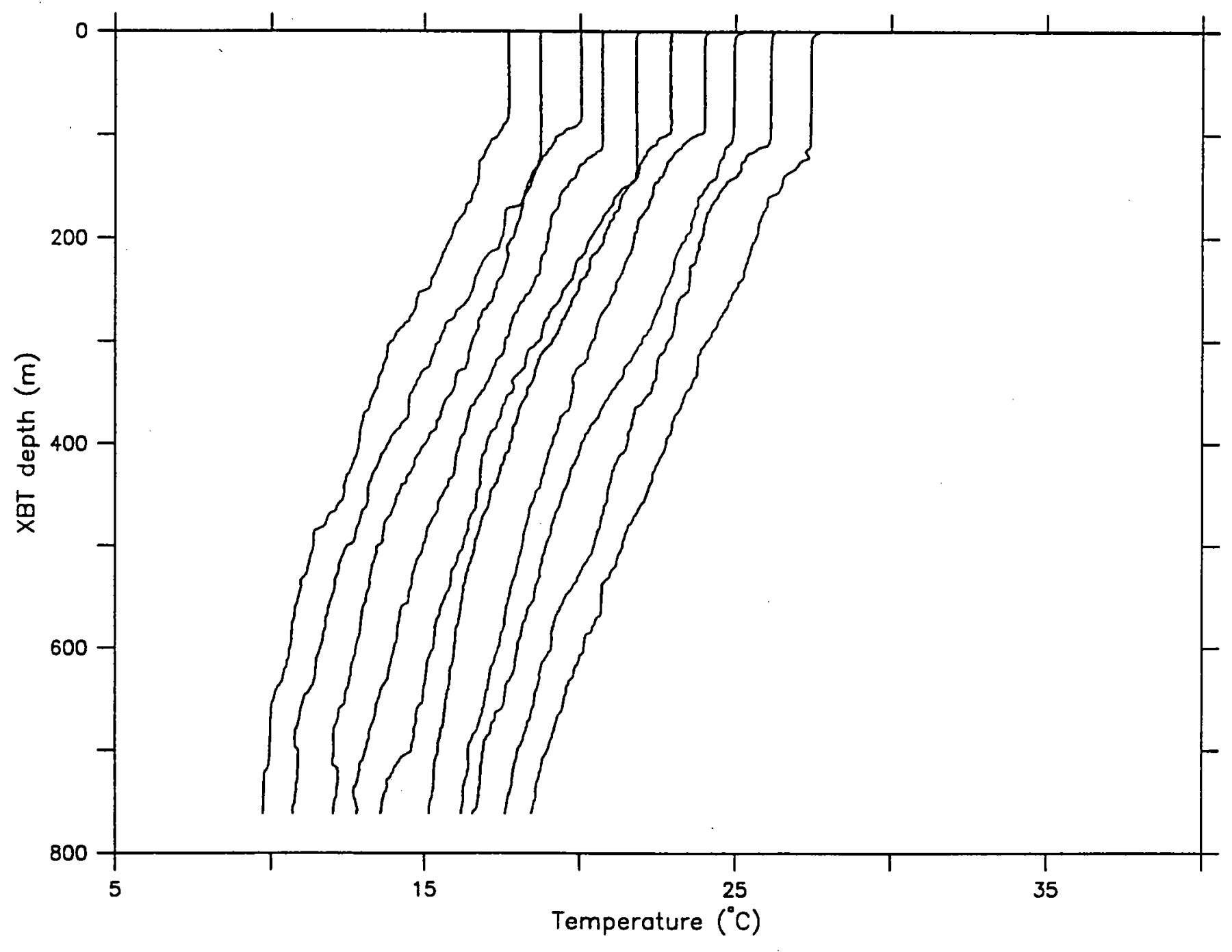

Subduction II XBT start: 280 offset by $1^{\circ} \mathrm{C}$ 
Figure A6-1dd. Overplot of XBT Profiles 290-299

Successive Profiles are offset by $1^{0} \mathrm{C}$.

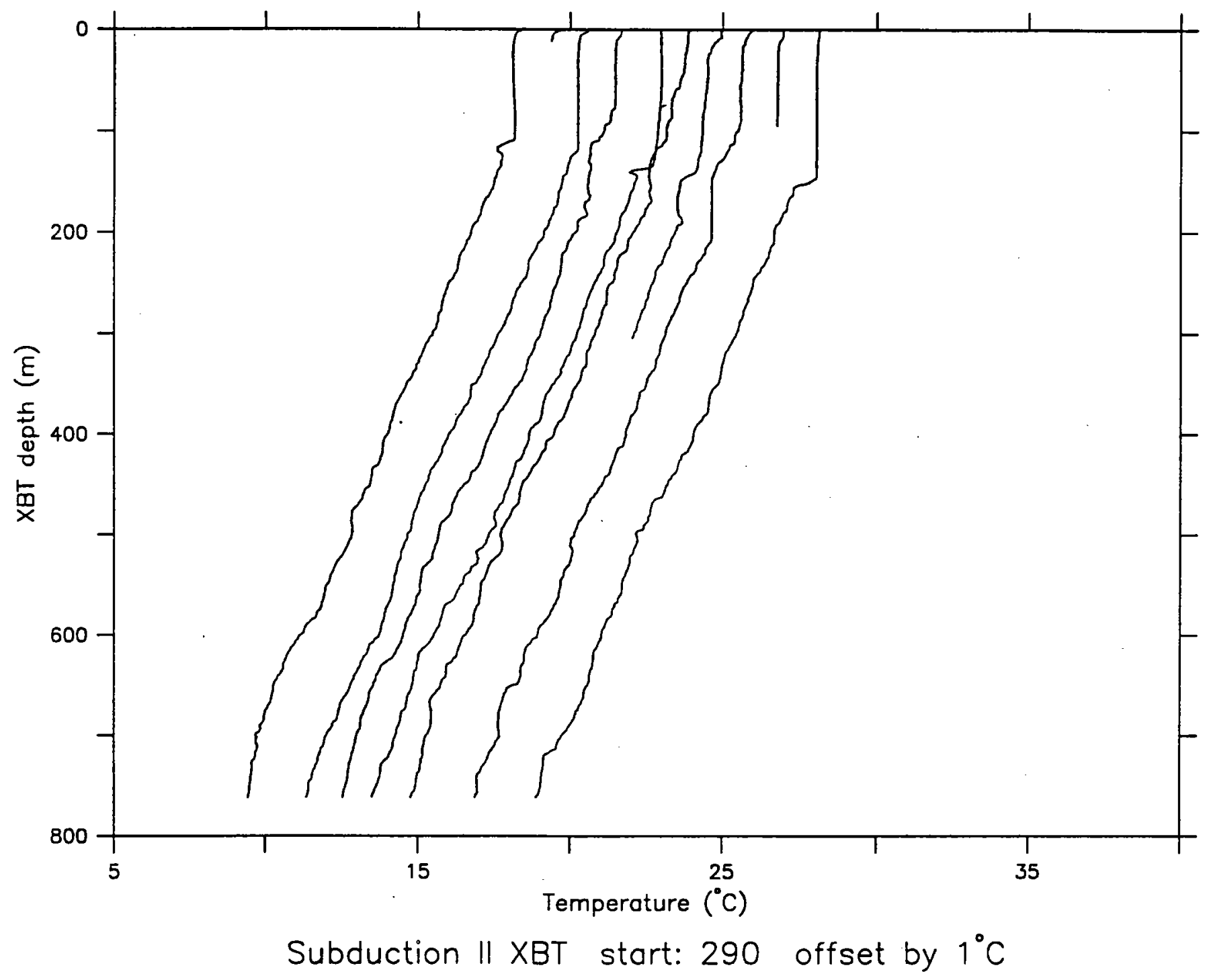


Figure A6-1ee. Overplot of XBT Profiles 300-309

Successive Profiles are offset by $1^{\circ} \mathrm{C}$.

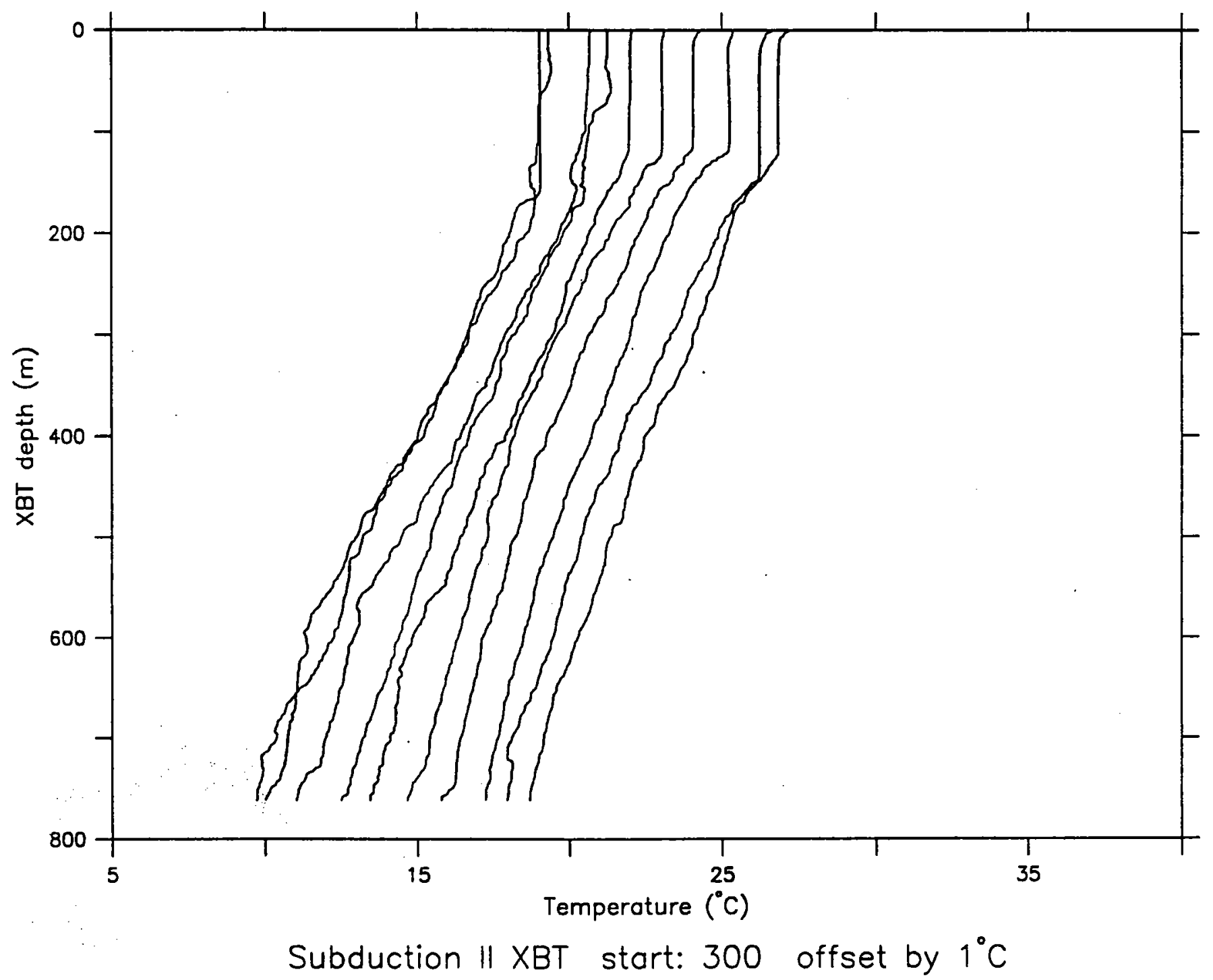




\section{Table A6-1 XBT Positions}

\begin{tabular}{|c|c|c|c|c|}
\hline & $\begin{array}{l}\text { No. } \\
\text { (1992) }\end{array}$ & $\begin{array}{l}\text { Time } \\
\text { (UTC) }\end{array}$ & $\begin{array}{l}\text { Position (GPS } \\
\text { Latitude (N) }\end{array}$ & Longitude (W) \\
\hline 2 & 26 January & 1505 & $36^{\circ} 58.13^{\prime}$ & $68^{\circ} \quad 38.76^{\prime}$ \\
\hline 3 & & 1900 & $36^{\circ} 23.48^{\prime}$ & $67051.20^{\prime}$ \\
\hline 4 & & 2300 & $35^{\circ} 52.49^{\prime}$ & $67^{\circ} 18.52^{\prime}$ \\
\hline 5 & 27 January & 0300 & $\begin{array}{ll}35^{\circ} & 20.00^{\prime}\end{array}$ & $66^{\circ} \quad 46.41^{\prime}$ \\
\hline 7 & & 0600 & $34^{\circ} 58.89^{\prime}$ & $\begin{array}{ll}66^{\circ} & 23.79^{\prime}\end{array}$ \\
\hline 8 & & 1000 & $34^{\circ} 33.51^{\prime}$ & $\begin{array}{ll}66^{\circ} & 04.55^{\prime}\end{array}$ \\
\hline 9 & & 1400 & $34^{\circ} \quad 04.79^{\prime}$ & $\begin{array}{ll}65^{\circ} & 28.75^{\prime}\end{array}$ \\
\hline 10 & & 1800 & $33^{\circ} 36.71^{\prime}$ & $65^{\circ} \quad 28.77^{\prime}$ \\
\hline 11 & & 2200 & $33^{\circ} 08.41^{\prime}$ & $64^{\circ} \quad 30.86^{\prime}$ \\
\hline 12 & 28 January & 0200 & $32^{\circ} 30.19^{\prime}$ & $63^{\circ} \quad 49.85^{\prime}$ \\
\hline 13 & & 0600 & $31^{\circ} 57.15^{\prime}$ & $63^{\circ} 00.98^{\prime}$ \\
\hline 14 & & 1000 & $\begin{array}{ll}31^{\circ} & 25.21^{\prime}\end{array}$ & $62^{\circ} \quad 27.39^{\prime}$ \\
\hline 15 & & 1400 & $30^{\circ} 53.01^{\prime}$ & $61^{\circ} \quad 46.04^{\prime}$ \\
\hline 16 & & 1800 & $30^{\circ} \quad 19.38^{\prime}$ & $61^{\circ} \quad 46.04^{\prime}$ \\
\hline 17 & & 2200 & $290 \quad 46.74^{\prime}$ & $60^{\circ} 29.82^{\prime}$ \\
\hline 18 & 29 January & 0200 & $290 \quad 09.02^{\prime}$ & $590 \quad 47.76^{\prime}$ \\
\hline 19 & & 0600 & $28^{\circ} 32.43^{\prime}$ & $\begin{array}{lll}59^{\circ} & 08.44^{\prime}\end{array}$ \\
\hline 20 & & 1000 & $27^{\circ} \quad 58.54^{\prime}$ & $58^{\circ} \quad 33.60^{\prime}$ \\
\hline 21 & & 1400 & $27^{\circ} \quad 26.06^{\prime}$ & $57^{\circ} \quad 58.51^{\prime}$ \\
\hline 22 & & 1800 & $26^{\circ} 51.81^{\prime}$ & $57^{\circ} \quad 23.39^{\prime}$ \\
\hline 23 & & 2200 & $26^{\circ} \quad 18.09^{\prime}$ & $56^{\circ} \quad 48.59^{\prime}$ \\
\hline 24 & 30 January & 0200 & $25^{\circ} \quad 44.98^{\prime}$ & $56^{\circ} \quad 12.29^{\prime}$ \\
\hline 25 & & 0600 & $25^{\circ} \quad 11.05^{\prime}$ & $55^{\circ} \quad 34.59^{\prime}$ \\
\hline 26 & & 1000 & $24^{\circ} 35.07^{\prime}$ & $54^{\circ} \quad 58.25^{\prime}$ \\
\hline 27 & & 1400 & $24^{\circ} 01.27^{\prime}$ & $54^{\circ} \quad 24.93^{\prime}$ \\
\hline 28 & & 1800 & $23^{\circ} 27.51^{\prime}$ & $53^{\circ} \quad 49.63^{\prime}$ \\
\hline 29 & & 2200 & $22^{\circ} 53.60^{\prime}$ & $53^{\circ} \quad 14.80^{\prime}$ \\
\hline 30 & 31 January & 0200 & $22^{\circ} \quad 17.24^{\prime}$ & $52^{\circ} \quad 39.30^{\prime}$ \\
\hline 31 & & 0500 & $21^{\circ} 52.02^{\prime}$ & $52^{\circ} \quad 13.71^{\prime}$ \\
\hline 32 & & 0900 & $21^{\circ} \quad 17.29^{\prime}$ & $51^{\circ} \quad 36.35^{\prime}$ \\
\hline 33 & & 1300 & $20^{\circ} \quad 40.20^{\prime}$ & $50^{\circ} \quad 57.31^{\prime}$ \\
\hline 34 & & 1700 & $20^{\circ} \quad 04.69^{\prime}$ & $50^{\circ} 21.64^{\prime}$ \\
\hline 35 & & 2100 & $19028.57^{\prime}$ & $49^{\circ} \quad 46.05^{\prime}$ \\
\hline 36 & 1 February & 0100 & $18^{\circ} 54.62^{\prime}$ & $49^{\circ} \quad 07.85^{\prime}$ \\
\hline 37 & & 0400 & $18^{\circ} 31.78^{\prime}$ & $48^{\circ} 39.01^{\prime}$ \\
\hline 38 & & 0800 & $17^{\circ} 59.87^{\prime}$ & $\begin{array}{ll}48^{\circ} & 01.27^{\prime}\end{array}$ \\
\hline 39 & & 1200 & $17^{\circ} 27.97^{\prime}$ & $47^{\circ} 25.11^{\prime}$ \\
\hline 40 & & 1600 & $16^{\circ} 57.61^{\prime}$ & $\begin{array}{ll}46^{\circ} & 48.47^{\prime}\end{array}$ \\
\hline 41 & & 2000 & $16^{\circ} 27.50^{\prime}$ & $\begin{array}{ll}46^{\circ} & 09.89^{\prime}\end{array}$ \\
\hline 42 & 2 February & 0000 & $15^{\circ} 58.13^{\prime}$ & $45^{\circ} \quad 34.24^{\prime}$ \\
\hline 43 & & 0400 & $15^{\circ} 23.13^{\prime}$ & $44^{\circ} 56.93^{\prime}$ \\
\hline 44 & & 0517 & $15^{\circ} \quad 13.09^{\prime}$ & $44^{\circ} \quad 47.48^{\prime}$ \\
\hline
\end{tabular}




\begin{tabular}{|c|c|c|c|c|c|c|}
\hline 45 & & 0800 & $15^{\circ}$ & $15.15^{\prime}$ & $44^{\circ}$ & $42.26^{\prime}$ \\
\hline 46 & & 1200 & $15^{\circ}$ & $28.81^{\circ}$ & $43^{\circ}$ & $53.88^{\prime}$ \\
\hline 47 & & 1600 & $15^{\circ}$ & $43.04^{\prime}$ & $43^{\circ}$ & $03.13^{\prime}$ \\
\hline 48 & & 2000 & $15^{\circ}$ & $55.46^{\prime}$ & $42^{\circ}$ & $15.77^{\prime}$ \\
\hline 49 & 3 February & 0000 & $16^{\circ}$ & $06.50^{\prime}$ & $41^{\circ}$ & $26.40^{\prime}$ \\
\hline 50 & & 0400 & $16^{\circ}$ & $19.39^{\prime}$ & $40^{\circ}$ & $36.78^{\prime}$ \\
\hline 51 & & 0800 & $16^{\circ}$ & $32.81^{\prime}$ & 390 & $46.63^{\prime}$ \\
\hline 52 & & 1200 & $16^{\circ}$ & $46.89^{\prime}$ & $38^{\circ}$ & $55.41^{\prime}$ \\
\hline 53 & & 1600 & $17^{\circ}$ & 01.96 & $38^{\circ}$ & $09.00^{\prime}$ \\
\hline 54 & & 2000 & $17^{\circ}$ & $12.43^{\prime}$ & $37^{\circ}$ & $22.67^{\prime}$ \\
\hline 55 & 4 February & 0000 & $17^{\circ}$ & $23.94^{\prime}$ & $36^{\circ}$ & $30.49^{\prime}$ \\
\hline 56 & & 0400 & $17^{\circ}$ & $35.98^{\prime}$ & $35^{\circ}$ & $39.90^{\prime}$ \\
\hline 57 & & 0800 & $17^{\circ}$ & $47.65^{\prime}$ & $34^{\circ}$ & $50.94^{\prime}$ \\
\hline 58 & & 1900 & $17^{\circ}$ & $59.82^{\prime}$ & 330 & $49.03^{\prime}$ \\
\hline 59 & & 2000 & $17^{\circ}$ & $59.75^{\prime}$ & $33^{\circ}$ & 37.03' \\
\hline 60 & & 2100 & $17^{\circ}$ & $59.40^{\prime}$ & $33^{\circ}$ & $24.92^{\prime}$ \\
\hline 61 & & 2200 & $17^{\circ}$ & $59.39^{\prime}$ & 330 & $12.28^{\prime}$ \\
\hline 62 & & 2300 & $17^{\circ}$ & $59.56^{\circ}$ & $32^{\circ}$ & $59.80^{\prime}$ \\
\hline 63 & 5 February & 0000 & $17^{\circ}$ & $59.61^{\prime}$ & $32^{\circ}$ & $47.51^{\prime}$ \\
\hline 64 & & 0100 & $17^{\circ}$ & $59.48^{\prime}$ & 320 & $35.15^{\circ}$ \\
\hline 65 & & 0200 & $17^{\circ}$ & $59.23^{\prime}$ & $32^{\circ}$ & $21.75^{\circ}$ \\
\hline 66 & & 0300 & $17^{\circ}$ & $59.42^{\prime}$ & 320 & $09.34^{\prime}$ \\
\hline 67 & & 0400 & $17^{\circ}$ & $59.56^{\prime}$ & 310 & $56.80^{\prime}$ \\
\hline 68 & & 0500 & $17^{\circ}$ & $59.85^{\prime}$ & $31^{\circ}$ & $44.32^{\prime}$ \\
\hline 69 & & 0600 & $18^{\circ}$ & $00.19^{\prime}$ & $31^{\circ}$ & $32.07^{\prime}$ \\
\hline 70 & & 0700 & $18^{\circ}$ & $00.31^{\prime}$ & 310 & $19.66^{\prime}$ \\
\hline 71 & & 0800 & $18^{\circ}$ & $00.74^{\prime}$ & $31^{\circ}$ & $07.71^{\prime}$ \\
\hline 72 & & 0900 & $18^{\circ}$ & $01.25^{\prime}$ & $30^{\circ}$ & $55.86^{\prime}$ \\
\hline 73 & & 1000 & $18^{\circ}$ & $01.17^{\prime}$. & $30^{\circ}$ & $43.09^{\prime}$ \\
\hline 74 & & 1100 & $18^{\circ}$ & $09.90^{\circ}$ & $30^{\circ}$ & $31.42^{\prime}$ \\
\hline 75 & & 1200 & $18^{\circ}$ & 01.05' & $30^{\circ}$ & $20.44^{\prime}$ \\
\hline 76 & & 1300 & $18^{\circ}$ & $01.17^{\prime}$ & $30^{\circ}$ & $05.71^{\circ}$ \\
\hline 77 & & 1400 & $18^{\circ}$ & $00.81^{\prime}$ & 290 & $55.06^{\prime}$ \\
\hline 78 & & 1500 & $18^{\circ}$ & $00.43^{\prime}$ & 290 & $42.92^{\prime}$ \\
\hline 79 & & 1600 & $17^{\circ}$ & $59.86^{\prime}$ & 290 & $30.42^{\prime}$ \\
\hline 80 & & 1700 & $17^{\circ}$ & $59.96^{\prime}$ & 290 & $18.58^{\circ}$ \\
\hline 81 & & 1800 & $18^{\circ}$ & $00.10^{\prime}$ & 290 & 08.83' \\
\hline 82 & & 1900 & 180 & $00.13^{\prime}$ & 280 & $56.54^{\prime}$ \\
\hline 83 & & 2000 & $17^{\circ}$ & $59.90^{\prime}$ & 280 & $45.05^{\prime}$ \\
\hline 84 & & 2100 & $17^{\circ}$ & $59.34^{\prime}$ & 280 & $32.59^{\prime}$ \\
\hline 85 & & 2200 & $17^{\circ}$ & $59.44^{\prime}$ & 280 & $20.44^{\prime}$ \\
\hline 86 & & 2300 & $17^{\circ}$ & $59.41^{\prime}$ & 280 & $08.41^{\prime}$ \\
\hline 87 & 6 February & 0000 & $17^{\circ}$ & $59.52^{\prime}$ & $27^{\circ}$ & $56.61^{\prime}$ \\
\hline 88 & & 0100 & $17^{\circ}$ & $59.56^{\prime}$ & $27^{\circ}$ & $44.58^{\prime}$ \\
\hline 89 & & 0200 & $17^{\circ}$ & $59.86^{\prime}$ & $27^{\circ}$ & $31.38^{\prime}$ \\
\hline 90 & & 0300 & $18^{\circ}$ & $00.07^{\prime}$ & $27^{\circ}$ & $19.21^{\prime}$ \\
\hline
\end{tabular}




\begin{tabular}{|c|c|c|c|c|c|c|}
\hline 91 & & 0400 & $18^{\circ}$ & $00.14^{\prime}$ & $27^{\circ}$ & $07.00^{\prime}$ \\
\hline 92 & & 0500 & $18^{\circ}$ & $00.43^{\prime}$ & $26^{\circ}$ & $54.91^{\prime}$ \\
\hline 93 & & 0600 & $18^{\circ}$ & $00.29^{\prime}$ & $26^{\circ}$ & $43.06^{\prime}$ \\
\hline 94 & & 0700 & $17^{\circ}$ & $59.89^{\prime}$ & $26^{\circ}$ & $30.34^{\prime}$ \\
\hline 95 & & 0800 & $17^{\circ}$ & $59.64^{\prime}$ & $26^{\circ}$ & $17.45^{\prime}$ \\
\hline 96 & & 0900 & $17^{\circ}$ & $59.51^{\prime}$ & $26^{\circ}$ & $05.14^{\prime}$ \\
\hline 97 & & 1000 & $17^{\circ}$ & $59.29^{\prime}$ & $25^{\circ}$ & $53.19^{\prime}$ \\
\hline 98 & & 1100 & $17^{\circ}$ & $59.14^{\prime}$ & $25^{\circ}$ & $40.27^{\prime}$ \\
\hline 99 & & 1200 & $17^{\circ}$ & 59.12 & $25^{\circ}$ & $28.37^{\prime}$ \\
\hline 100 & & 1300 & $17^{\circ}$ & $59.47^{\prime}$ & $25^{\circ}$ & $15.92^{\prime}$ \\
\hline 101 & & 1400 & $17^{\circ}$ & $59.87^{\prime}$ & $25^{\circ}$ & $03.55^{\prime}$ \\
\hline 102 & & 1500 & $18^{\circ}$ & $00.07^{\prime}$ & $24^{\circ}$ & $50.95^{\prime}$ \\
\hline 103 & & 1600 & $18^{\circ}$ & $00.18^{\prime}$ & $24^{\circ}$ & $38.78^{\prime}$ \\
\hline 104 & & 1700 & 180 & $00.30^{\prime}$ & $24^{\circ}$ & $27.25^{\prime}$ \\
\hline 105 & & 1800 & $17^{\circ}$ & $59.99^{\prime}$ & $24^{\circ}$ & $14.75^{\prime}$ \\
\hline 106 & & 1900 & $17^{\circ}$ & $59.98^{\prime}$ & $24^{\circ}$ & $02.79^{\prime}$ \\
\hline 107 & & 2000 & $18^{\circ}$ & $00.08^{\prime}$ & 230 & $51.03^{\prime}$ \\
\hline 108 & & 2100 & $18^{\circ}$ & $00.01^{\prime}$ & $23^{\circ}$ & $38.98^{\prime}$ \\
\hline 109 & & 2200 & $17^{\circ}$ & $59.98^{\prime}$ & $23^{\circ}$ & $26.87^{\prime}$ \\
\hline 110 & & 2300 & $18^{\circ}$ & $00.04^{\prime}$ & 230 & $15.09^{\prime}$ \\
\hline 111 & 7 February & 0000 & $18^{\circ}$ & $00.72^{\prime}$ & $23^{\circ}$ & $03.22^{\prime}$ \\
\hline 112 & & 0100 & $18^{\circ}$ & $01.16^{\prime}$ & 220 & $51.43^{\prime}$ \\
\hline 113 & & 0200 & 180 & $00.97^{\prime}$ & 220 & $38.95^{\prime}$ \\
\hline 114 & & 0300 & 180 & $00.63^{\prime}$ & $22^{\circ}$ & $26.73^{\prime}$ \\
\hline 115 & & 0400 & 180 & $00.15^{\prime}$ & 220 & $14.84^{\prime}$ \\
\hline 116 & 9 February & 1000 & $18^{\circ}$ & $09.49^{\prime}$ & 220 & 09.70' \\
\hline 117 & & 1100 & $18^{\circ}$ & $18.16^{\prime}$ & $22^{\circ}$ & $17.06^{\circ}$ \\
\hline 118 & & 1200 & 180 & $27.58^{\prime}$ & 220 & $25.19^{\prime}$ \\
\hline 119 & & 1300 & 180 & $37.20^{\prime}$ & 220 & $33.18^{\prime}$ \\
\hline $120^{\circ}$ & & 1400 & $18^{\circ}$ & $46.18^{\prime}$ & $22^{\circ}$ & $40.96^{\prime}$ \\
\hline 121 & & 1500 & 180 & $55.31^{\prime}$ & $22^{\circ}$ & 49.02' \\
\hline 122 & & 1600 & 190 & $04.52^{\prime}$ & $22^{\circ}$ & $57.37^{\prime}$ \\
\hline 123 & & 1700 & 190 & $12.98^{\prime}$ & $23^{\circ}$ & $05.51^{\prime}$ \\
\hline 124 & & 1800 & 190 & $21.87^{\prime}$ & $23^{\circ}$ & $14.40^{\prime}$ \\
\hline 125 & & 1900 & 190 & $30.59^{\prime}$ & $23^{\circ}$ & $23.05^{\prime}$ \\
\hline 126 & & 2000 & 190 & $39.99^{\prime}$ & $23^{\circ}$ & $32.36^{\prime}$ \\
\hline 127 & & 2100 & $19^{\circ}$ & $48.95^{\prime}$ & $23^{\circ}$ & $40.95^{\prime}$ \\
\hline 128 & & 2200 & 190 & $57.60^{\prime}$ & $23^{\circ}$ & $49.28^{\prime}$ \\
\hline 129 & & 2300 & $20^{\circ}$ & $06.27^{\prime}$ & $23^{\circ}$ & $59.68^{\prime}$ \\
\hline 131 & 10 February & 0000 & $20^{\circ}$ & $14.98^{\prime}$ & $24^{\circ}$ & $05.89^{\prime}$ \\
\hline 132 & & 0100 & $20^{\circ}$ & $24.63^{\prime}$ & 240 & $14.88^{\prime}$ \\
\hline 133 & & 0200 & $20^{\circ}$ & $33.52^{\prime}$ & $24^{\circ}$ & $22.56^{\prime}$ \\
\hline 134 & & 0300 & $20^{\circ}$ & $42.77^{\prime}$ & $24^{\circ}$ & $30.30^{\prime}$ \\
\hline 135 & & 0400 & $20^{\circ}$ & $51.51^{\prime}$ & 240 & $37.84^{\prime}$ \\
\hline 136 & & 0500 & $21^{\circ}$ & $00.33^{\prime}$ & $24^{\circ}$ & $45.47^{\prime}$ \\
\hline 137 & & 0600 & $21^{\circ}$ & 08.90' & $24^{\circ}$ & $53.14^{\prime}$ \\
\hline
\end{tabular}




\begin{tabular}{|c|c|c|c|c|c|c|}
\hline 138 & & 0700 & $21^{\circ}$ & $17.71^{\prime}$ & $25^{\circ}$ & $01.31^{\prime}$ \\
\hline 139 & & 0800 & 210 & $26.64^{\prime}$ & $25^{\circ}$ & $09.42^{\prime}$ \\
\hline 140 & & 0900 & $21^{\circ}$ & $35.61^{\prime}$ & $25^{\circ}$ & $17.65^{\prime}$ \\
\hline 142 & & 1000 & $21^{\circ}$ & $44.53^{\prime}$ & $25^{\circ}$ & $25.64^{\prime}$ \\
\hline 143 & & 1100 & $21^{\circ}$ & $53.34^{\prime}$ & $25^{\circ}$ & $33.93^{\prime}$ \\
\hline 144 & & 1200 & $22^{\circ}$ & $02.78^{\prime}$ & $25^{\circ}$ & $42.92^{\prime}$ \\
\hline 145 & & 1300 & $22^{\circ}$ & $12.24^{\prime}$ & $25^{\circ}$ & $51.62^{\prime}$ \\
\hline 146 & & 1400 & 220 & $21.59^{\prime}$ & $26^{\circ}$ & $00.42^{\prime}$ \\
\hline 147 & & 1500 & $22^{\circ}$ & $30.63^{\prime}$ & $26^{\circ}$ & $08.94^{\prime}$ \\
\hline 149 & & 1600 & $22^{\circ}$ & $39.96^{\prime}$ & $26^{\circ}$ & $17.46^{\prime}$ \\
\hline 150 & & 1700 & $22^{\circ}$ & $48.89^{\prime}$ & $26^{\circ}$ & $25.68^{\prime}$ \\
\hline 151 & & 1800 & $22^{\circ}$ & $58.07^{\prime}$ & $26^{\circ}$ & $33.48^{\prime}$ \\
\hline 152 & & 1900 & $23^{\circ}$ & $07.06^{\prime}$ & $26^{\circ}$ & $41.48^{\prime}$ \\
\hline 153 & & 2000 & $23^{\circ}$ & $16.10^{\prime}$ & $26^{\circ}$ & $49.68^{\prime}$ \\
\hline 155 & & 2100 & $23^{\circ}$ & $25.26^{\prime}$ & $26^{\circ}$ & $57.97^{\prime}$ \\
\hline 156 & & 2200 & $23^{\circ}$ & $34.28^{\prime}$ & $27^{\circ}$ & $06.06^{\circ}$ \\
\hline 157 & & 2300 & $23^{\circ}$ & $43.29^{\prime}$ & $27^{\circ}$ & $14.41^{\prime}$ \\
\hline 158 & 11 February & 0000 & 230 & $52.28^{\prime}$ & $27^{\circ}$ & $22.65^{\prime}$ \\
\hline 159 & & 0100 & $24^{\circ}$ & $01.54^{\prime}$ & $27^{\circ}$ & $31.01^{\circ}$ \\
\hline 160 & & 0200 & $24^{\circ}$ & $10.39^{\prime}$ & $27^{\circ}$ & $39.25^{\prime}$ \\
\hline 161 & & 0300 & $24^{\circ}$ & $19.17^{\prime}$ & $27^{\circ}$ & $47.66^{\prime}$ \\
\hline 162 & & 0400 & $24^{\circ}$ & $28.47^{\prime}$ & $27^{\circ}$ & $56.64^{\prime}$ \\
\hline 163 & & 0500 & $24^{\circ}$ & $37.24^{\prime}$ & 280 & $04.93^{\prime}$ \\
\hline 165 & & 0603 & $24^{\circ}$ & $46.99^{\prime}$ & 280 & $14.38^{\prime}$ \\
\hline 166 & & 0700 & $24^{\circ}$ & $54.97^{\prime}$ & 280 & $22.21^{\prime}$ \\
\hline 167 & & 0800 & $25^{\circ}$ & $03.58^{\prime}$ & 280 & 30.8 \\
\hline 168 & & 0900 & $25^{\circ}$ & $12.47^{\prime}$ & 280 & $39.86^{\prime}$ \\
\hline 169 & & 1000 & $25^{\circ}$ & $21.26^{\prime}$ & $28^{\circ}$ & $48.60^{\prime}$ \\
\hline 170 & 13 February & 0200 & $25^{\circ}$ & $31.82^{\prime}$ & 280 & $57.79^{\prime}$ \\
\hline 171 & & 0300 & $25^{\circ}$ & $50.13^{\prime}$ & 280 & 41.05 \\
\hline 172 & & 0400 & $25^{\circ}$ & $59.70^{\prime}$ & 280 & $31.93^{\prime}$ \\
\hline 173 & & 0500 & $26^{\circ}$ & $08.61^{\prime}$ & 280 & $23.42^{\prime}$ \\
\hline 174 & & 0600 & $26^{\circ}$ & $18.36^{\prime}$ & $28^{\circ}$ & $14.25^{\prime}$ \\
\hline 175 & & 0700 & $26^{\circ}$ & $27.67^{\prime}$ & $28^{\circ}$ & $05.35^{\prime}$ \\
\hline 176 & & 0800 & $26^{\circ}$ & $37.39^{\prime}$ & $27^{\circ}$ & $55.96^{\prime}$ \\
\hline 177 & & 0900 & $26^{\circ}$ & $46.68^{\prime}$ & $27^{\circ}$ & $46.90^{\prime}$ \\
\hline 178 & & 1000 & $26^{\circ}$ & $56.24^{\prime}$ & $27^{\circ}$ & $37.48^{\prime}$ \\
\hline 179 & & 1100 & $27^{\circ}$ & $05.71^{\prime}$ & $27^{\circ}$ & $27.80^{\prime}$ \\
\hline 180 & & 1200 & $27^{\circ}$ & $14.94^{\prime}$ & $27^{\circ}$ & $18.77^{\prime}$ \\
\hline 181 & & 1300 & $27^{\circ}$ & $24.78^{\prime}$ & $27^{\circ}$ & $09.33^{\prime}$ \\
\hline 182 & & 1400 & $27^{\circ}$ & $33.85^{\prime}$ & $27^{\circ}$ & $01.39^{\prime}$ \\
\hline 183 & & 1500 & $27^{\circ}$ & $44.35^{\prime}$ & $26^{\circ}$ & $53.33^{\prime}$ \\
\hline 184 & & 1600 & $27^{\circ}$ & $54.44^{\prime}$ & $26^{\circ}$ & $48.75^{\prime}$ \\
\hline 185 & & 1700 & $28^{\circ}$ & $04.11^{\prime}$ & $26^{\circ}$ & $40.43^{\prime}$ \\
\hline 186 & & 1800 & $28^{\circ}$ & $13.83^{\prime}$ & $26^{\circ}$ & $32.16^{\prime}$ \\
\hline 187 & & 1900 & $28^{\circ}$ & $23.74^{\prime}$ & $26^{\circ}$ & $23.02^{\prime}$ \\
\hline
\end{tabular}




\begin{tabular}{|c|c|c|c|c|c|c|}
\hline 188 & & 2000 & $28^{\circ}$ & $33.44^{\prime}$ & $26^{\circ}$ & $13.50^{\prime}$ \\
\hline 189 & & 2100 & 280 & $42.98^{\prime}$ & $26^{\circ}$ & $04.06^{\prime}$ \\
\hline 191 & & 2200 & 280 & $52.43^{\prime}$ & $25^{\circ}$ & $54.82^{\prime}$ \\
\hline 192 & & 2300 & 290 & 01.99' & $25^{\circ}$ & 45.39' \\
\hline 194 & 14 February & 0020 & 290 & $15.12^{\prime}$ & $25^{\circ}$ & $32.78^{\prime}$ \\
\hline 195 & & 0100 & 290 & $22.02^{\prime}$ & $25^{\circ}$ & $26.05^{\prime}$ \\
\hline 198 & & 0209 & 290 & $32.31^{\prime}$ & $25^{\circ}$ & $16.36^{\prime}$ \\
\hline 199 & & 0300 & 290 & $40.93^{\prime}$ & $25^{\circ}$ & $08.40^{\prime}$ \\
\hline 200 & & 0400 & 290 & $50.54^{\prime}$ & $24^{\circ}$ & $59.38^{\prime}$ \\
\hline 201 & & 0500 & $30^{\circ}$ & $00.57^{\prime}$ & $24^{\circ}$ & $50.04^{\prime}$ \\
\hline 202 & & 0600 & $30^{\circ}$ & $10.29^{\prime}$ & $24^{\circ}$ & $41.15^{\prime}$ \\
\hline 203 & & 0700 & $30^{\circ}$ & $20.15^{\prime}$ & $24^{\circ}$ & $31.95^{\prime}$ \\
\hline 204 & & 0800 & $30^{\circ}$ & $30.19^{\prime}$ & $24^{\circ}$ & $22.52^{\prime}$ \\
\hline 205 & & 0900 & $30^{\circ}$ & $39.70^{\prime}$ & 240 & $13.50^{\prime}$ \\
\hline 206 & & 1000 & $30^{\circ}$ & $49.45^{\prime}$ & $24^{\circ}$ & $04.17^{\prime}$ \\
\hline 207 & & 1100 & $30^{\circ}$ & $59.38^{\prime}$ & $23^{\circ}$ & $54.63^{\prime}$ \\
\hline 208 & & 1200 & 310 & $09.21^{\prime}$ & $23^{\circ}$ & $45.20^{\prime}$ \\
\hline 209 & & 1300 & 310 & $19.23^{\prime}$ & $23^{\circ}$ & $35.33^{\circ}$ \\
\hline 210 & & 1400 & 310 & $29.19^{\prime}$ & 230 & $25.80^{\prime}$ \\
\hline 211 & & 1500 & 310 & $84.84^{\prime}$ & 230 & $16.44^{\prime}$ \\
\hline 212 & & 1600 & $31^{\circ}$ & $49.01^{\prime}$ & $23^{\circ}$ & $06.49^{\prime}$ \\
\hline 213 & & 1700 & $31^{\circ}$ & $58.79^{\prime}$ & 220 & $57.52^{\prime}$ \\
\hline 214 & & 1800 & 320 & $09.06^{\prime}$ & 220 & $47.92^{\prime}$ \\
\hline 215 & & 1900 & $32^{\circ}$ & $18.78^{\prime}$ & $22^{\circ}$ & $38.45^{\prime}$ \\
\hline 216 & & 2000 & $32^{\circ}$ & $28.94^{\prime}$ & $22^{\circ}$ & $28.34^{\prime}$ \\
\hline 217 & & 2100 & $32^{\circ}$ & $38.54^{\prime}$ & 220 & $18.47^{\prime}$ \\
\hline \multicolumn{3}{|c|}{ Madeira } & & 0 & & \\
\hline 218 & 19 February & 1200 & $32^{\circ}$ & $41.16^{\prime}$ & $17^{\circ}$ & $43.91^{\prime}$ \\
\hline 219 & & 1300 & $32^{\circ}$ & $42.66^{\prime}$ & $17^{\circ}$ & $57.06^{\prime}$ \\
\hline 220 & & 1400 & $32^{\circ}$ & $43.97^{\prime}$ & 180 & $10.17^{\prime}$ \\
\hline 221 & & 1500 & $32^{\circ}$ & $45.21^{\prime}$ & $18^{\circ}$ & $23.96^{\circ}$ \\
\hline 222 & & 1600 & $32^{\circ}$ & $46.41^{\prime}$ & $18^{\circ}$ & 37.47 \\
\hline 223 & & 1700 & $32^{\circ}$ & $47.21^{\prime}$ & 180 & $49.43^{\prime}$ \\
\hline 234 & & 1800 & $32^{\circ}$ & $49.12^{\prime}$ & 190 & $00.29^{\prime}$ \\
\hline 235 & & 1900 & $32^{\circ}$ & $50.58^{\prime}$ & 190 & $12.60^{\circ}$ \\
\hline 236 & & 2000 & $32^{\circ}$ & $52.79^{\prime}$ & 190 & $29.25^{\prime}$ \\
\hline 237 & & 2100 & $32^{\circ}$ & $53.81^{\prime}$ & 190 & $40.43^{\prime}$ \\
\hline 238 & & 2200 & $32^{\circ}$ & $55.05^{\prime}$ & 190 & $53.40^{\prime}$ \\
\hline 239 & & 2300 & $32^{\circ}$ & $56.28^{\prime}$ & $20^{\circ}$ & $06.92^{\prime}$ \\
\hline 240 & 20 February & 0000 & $32^{\circ}$ & $57.32^{\prime}$ & $20^{\circ}$ & $20.37^{\prime}$ \\
\hline 241 & & 0100 & $32^{\circ}$ & $58.30^{\prime}$ & $20^{\circ}$ & $34.73^{\prime}$ \\
\hline 244 & & 0200 & $32^{\circ}$ & $59.45^{\prime}$ & $20^{\circ}$ & $50.74^{\prime}$ \\
\hline 245 & & 0300 & $32^{\circ}$ & $59.94^{\prime}$ & $21^{\circ}$ & $02.80^{\prime}$ \\
\hline 246 & & 0400 & 330 & $00.28^{\prime}$ & $21^{\circ}$ & $17.56^{\prime}$ \\
\hline
\end{tabular}




\begin{tabular}{|c|c|c|c|c|c|c|}
\hline 247 & & 0500 & 330 & $00.62^{\prime}$ & $21^{\circ}$ & $31.67^{\prime}$ \\
\hline 248 & & 2300 & $33^{\circ}$ & $00.73^{\prime}$ & 220 & $15.90^{\prime}$ \\
\hline 249 & 21 February & 0000 & 330 & $00.10^{\prime}$ & $22^{\circ}$ & 30.55 \\
\hline 250 & & 0100 & $33^{\circ}$ & $00.03^{\prime}$ & 220 & 44.9 \\
\hline 251 & & 0200 & 330 & $00.26^{\prime}$ & 220 & 58.57 \\
\hline 252 & & 0300 & 330 & $00.56^{\prime}$ & $23^{\circ}$ & 12.1 \\
\hline 253 & & 0400 & $33^{\circ}$ & $00.54^{\prime}$ & $23^{\circ}$ & 25.57 \\
\hline 254 & & 0500 & 330 & $00.77^{\prime}$ & 230 & 38.1 \\
\hline 255 & & 0600 & $33^{\circ}$ & $01.05^{\prime}$ & 230 & 52.47 \\
\hline 256 & & 0700 & $33^{\circ}$ & $01.10^{\prime}$ & $24^{\circ}$ & 07.1 \\
\hline 257 & & 0800 & 330 & $00.87^{\prime}$ & $24^{\circ}$ & 20.3 \\
\hline 258 & & 0900 & $33^{\circ}$ & $00.16^{\prime}$ & $24^{\circ}$ & 34.1 \\
\hline 259 & & 1000 & $32^{\circ}$ & $59.43^{\prime}$ & $24^{\circ}$ & $48.1^{\prime}$ \\
\hline 260 & & 1100 & 320 & $59.13^{\prime}$ & $25^{\circ}$ & 01.5 \\
\hline 261 & & 1200 & $32^{\circ}$ & $58.97^{\prime}$ & $25^{\circ}$ & 15.1 \\
\hline 262 & & 1300 & $32^{\circ}$ & $58.81^{\prime}$ & $25^{\circ}$ & 29.1 \\
\hline 263 & & 1400 & 320 & $59.05^{\prime}$ & $25^{\circ}$ & $43.01^{\prime}$ \\
\hline 264 & & 1500 & $32^{\circ}$ & $59.48^{\prime}$ & $25^{\circ}$ & 56.77 \\
\hline 265 & & 1600 & $32^{\circ}$ & $59.43^{\prime}$ & $26^{\circ}$ & $10.67^{\prime}$ \\
\hline 266 & & $1700^{\circ}$ & 320 & $59.84^{\prime}$ & $26^{\circ}$ & $23.32^{\prime}$ \\
\hline 267 & & 1800 & $32^{\circ}$ & $59.89^{\prime}$ & $26^{\circ}$ & $36.9^{\prime}$ \\
\hline 268 & & 1900 & 320 & $59.89^{\prime}$ & $26^{\circ}$ & 50.86 \\
\hline 269 & & 2000 & $32^{\circ}$ & $59.68^{\prime}$ & $27^{\circ}$ & 05.1 \\
\hline 270 & & 2100 & $32^{\circ}$ & $59.48^{\prime}$ & $27^{\circ}$ & 18.35 \\
\hline 271 & & 2200 & $32^{\circ}$ & $59.52^{\prime}$ & $27^{\circ}$ & 31.8 \\
\hline 272 & & 2300 & $32^{\circ}$ & $59.68^{\prime}$ & $27^{\circ}$ & 44.55 \\
\hline 273 & February 22 & 0000 & 320 & $59.67^{\prime}$ & $27^{\circ}$ & 57.6 \\
\hline 274 & & 0100 & $32^{\circ}$ & $59.87^{\prime}$ & 280 & 11.1 \\
\hline 275 & & 0200 & 320 & $59.63^{\prime}$ & 280 & 24.53 \\
\hline 276 & & 0300 & $32^{\circ}$ & $59.29^{\prime}$ & $28^{\circ}$ & 37.61 \\
\hline 277 & & 0400 & $32^{\circ}$ & $58.50^{\prime}$ & 280 & 50.6 \\
\hline 278 & & 0500 & 320 & $57.69^{\prime}$ & 290 & 03.48 \\
\hline 279 & & 0600 & $32^{\circ}$ & $57.11^{\prime}$ & 290 & 16.0 \\
\hline 280 & & 0700 & $32^{\circ}$ & $56.13^{\prime}$ & 290 & 30.32 \\
\hline 281 & & 0800 & $32^{\circ}$ & $55.92^{\prime}$ & 290 & 43.4 \\
\hline 282 & & 0900 & 320 & $55.85^{\prime}$ & 290 & 55.68 \\
\hline 283 & & 1000 & $32^{\circ}$ & $56.18^{\prime}$ & $30^{\circ}$ & 09.2 \\
\hline 284 & & 1100 & 320 & $56.82^{\prime}$ & 300 & 22.80 \\
\hline 285 & & 1200 & $32^{\circ}$ & $57.29^{\prime}$ & $30^{\circ}$ & 36.5 \\
\hline 286 & & 1300 & $32^{\circ}$ & $58.02^{\prime}$ & $30^{\circ}$ & 50.36 \\
\hline 287 & & 1400 & 320 & $58.16^{\prime}$ & $31^{\circ}$ & 04.1 \\
\hline 288 & & 1500 & $32^{\circ}$ & $57.65^{\prime}$ & $31^{\circ}$ & 17.8 \\
\hline 289 & & 1600 & $32^{\circ}$ & $56.88^{\prime}$ & $31^{\circ}$ & 31.3 \\
\hline 290 & & 1700 & 320 & $57.68^{\prime}$ & $31^{\circ}$ & 44.15 \\
\hline 292 & & 1800 & $32^{\circ}$ & $57.98^{\prime}$ & $31^{\circ}$ & 57.18 \\
\hline 293 & & 1900 & $32^{\circ}$ & $57.39^{\prime}$ & $32^{\circ}$ & 10.24 \\
\hline
\end{tabular}




\begin{tabular}{|c|c|c|c|c|c|c|}
\hline 294 & & 2000 & 320 & $56.80^{\prime}$ & $32^{\circ}$ & 23.91' \\
\hline 295 & & 2100 & 320 & $56.07^{\prime}$ & 320 & $36.69^{\prime}$ \\
\hline 296 & & 2200 & $32^{\circ}$ & $55.38^{\prime}$ & 320 & $49.96^{\prime}$ \\
\hline 297 & & 2300 & $32^{\circ}$ & $55.27^{\prime}$ & $32^{\circ}$ & $51.88^{\prime}$ \\
\hline 299 & 23 February & 0000 & $32^{\circ}$ & $54.29^{\prime}$ & $33^{\circ}$ & $17.44^{\prime}$ \\
\hline 300 & & 0100 & $32^{\circ}$ & $54.49^{\prime}$ & $33^{\circ}$ & $31.81^{\prime}$ \\
\hline 301 & 24 February & 0900 & $33^{\circ}$ & $15.55^{\prime}$ & $33^{\circ}$ & $15.89^{\prime}$ \\
\hline 302 & & 1000 & 330 & $22.88^{\prime}$ & 330 & $03.69^{\prime}$ \\
\hline 303 & & 1100 & 330 & $29.87^{\prime}$ & $32^{\circ}$ & $51.66^{\prime}$ \\
\hline 304 & & 1200 & $33^{\circ}$ & $36.25^{\prime}$ & $32^{\circ}$ & $40.60^{\prime}$ \\
\hline 305 & & 1300 & $33^{\circ}$ & $42.22^{\prime}$ & 320 & $30.76^{\prime}$ \\
\hline 306 & & 1400 & $33^{\circ}$ & $47.84^{\prime}$ & $32^{\circ}$ & $21.58^{\prime}$ \\
\hline 307 & & 1500 & $33^{\circ}$ & $53.38^{\prime}$ & $32^{\circ}$ & $12.28^{\prime}$ \\
\hline 308 & & 1600 & $33^{\circ}$ & $59.37^{\prime}$ & $32^{\circ}$ & $02.56^{\prime}$ \\
\hline 309 & & 1700 & $34 \mathrm{c}$ & $05.06^{\prime}$ & $31^{\circ}$ & $53.17^{\prime}$ \\
\hline 310 & & 1800 & 340 & $10.86^{\prime}$ & $31^{\circ}$ & $43.56^{\prime}$ \\
\hline 311 & & 1900 & 340 & $16.68^{\prime}$ & 310 & $33.63^{\prime}$ \\
\hline 312 & & 2000 & $34^{\circ}$ & $22.62^{\prime}$ & 310 & 24.32 \\
\hline
\end{tabular}


Figure A6-2 (a-d). XBT survey area during OCEANUS 250 and contour plots.

(a) SUBDUCTION Mooring positions Oceanus 250
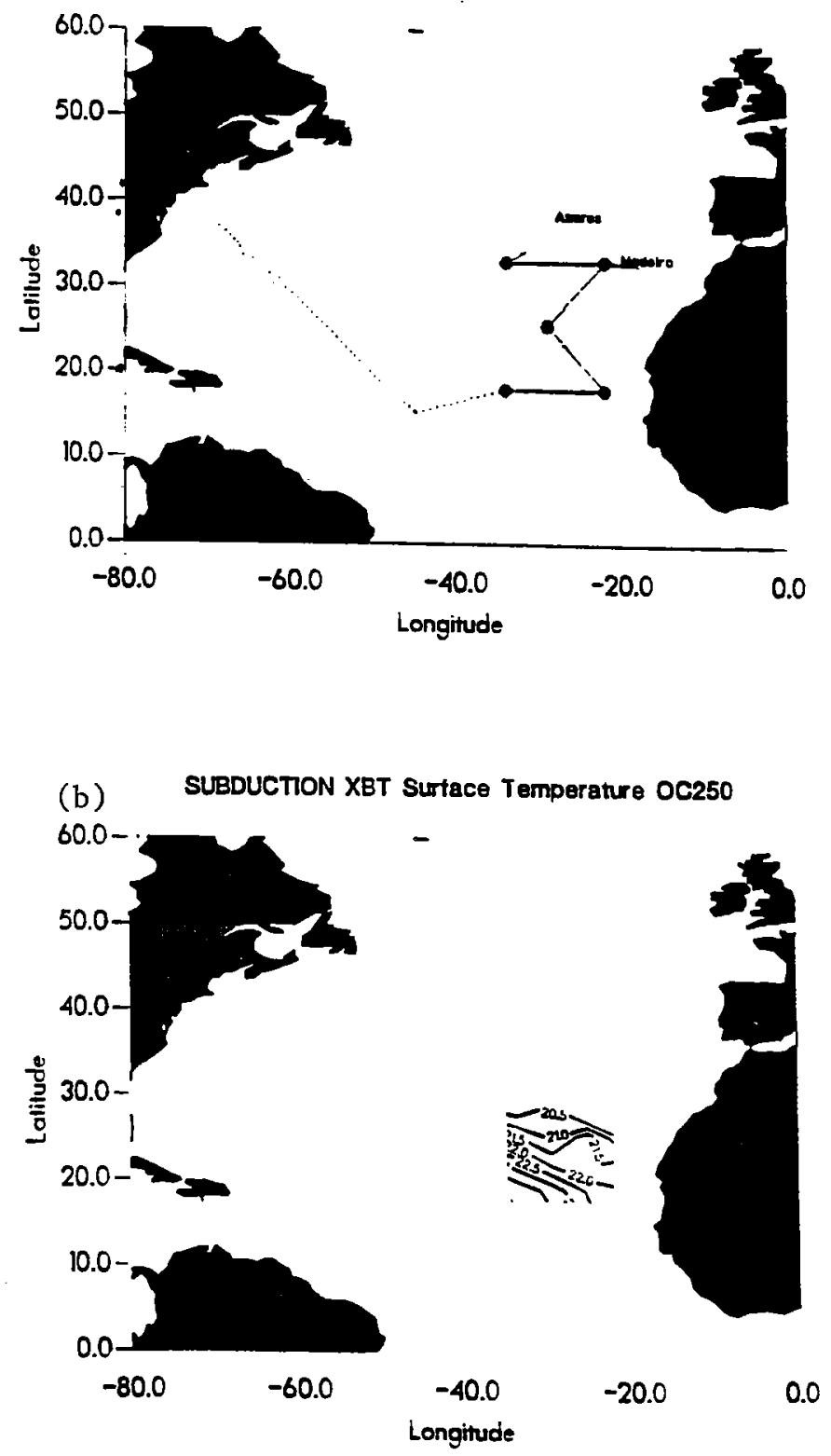

(c) SUBDUCTION $200 \mathrm{~m}$ Temperature OC250

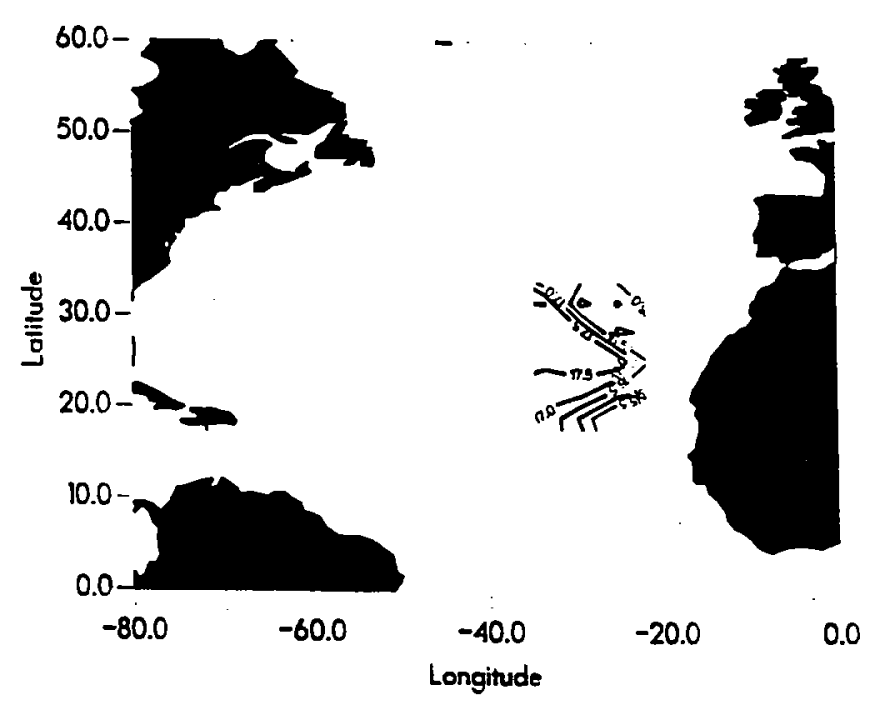

(d) SUBDUCTION $500 \mathrm{~m}$ Temperature OC250

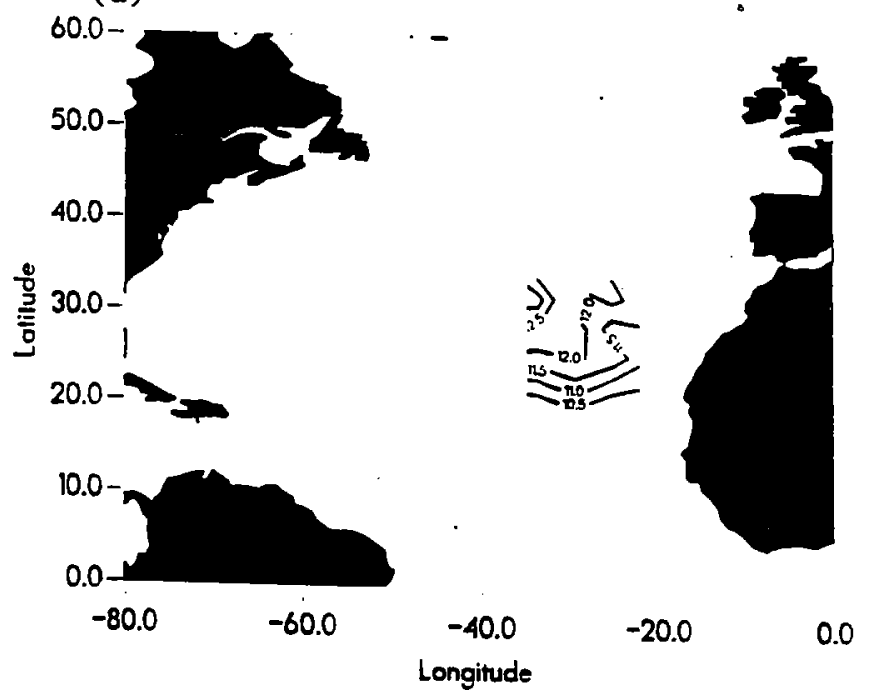


Figure A6-3. XBT section locations.

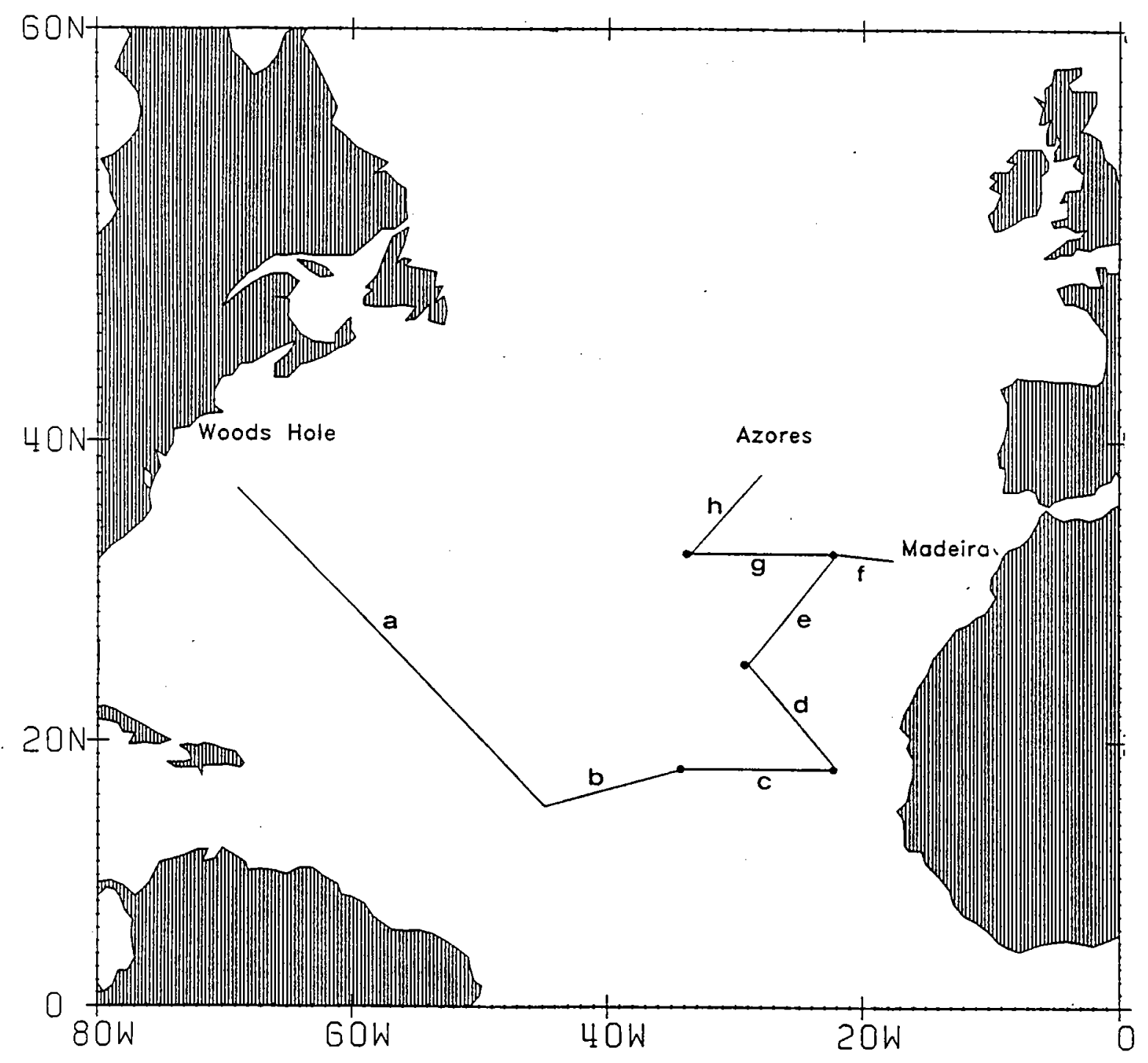

Section Location

Woods Hole to SW drifting buoy SW drifting buoy to SW anchor site SW anchor site to SE anchor site SE anchor site to $C$ anchor site $C$ anchor site to NE anchor site Madeira to NE anchor site NE anchor site to NW anchor site NW anchor site towards. Ponta Delgada
Section letter

$a$
$b$
$c$
$d$
$e$
$f$
$g$

XBTS included

$1 \cdot 44$

$45-57$

$58-115$

$116 \cdot 169$

$170-217$

218-246

$247-300$

$300-312$ 
Figure A6-4a. Contoured XBT sections in Subduction array area.
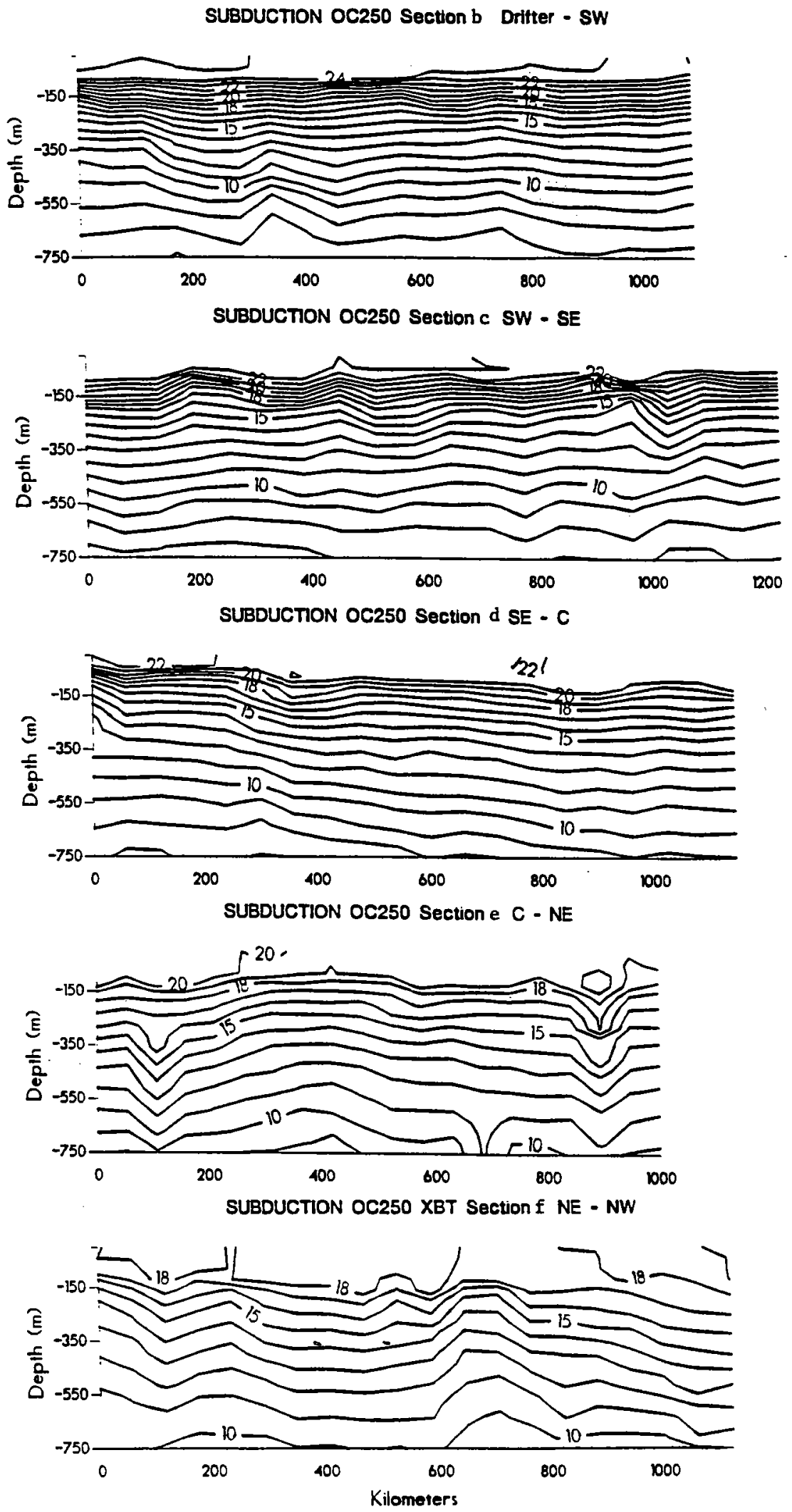
Figure A6-4b . Contoured XBT sections in Subduction transit areas.
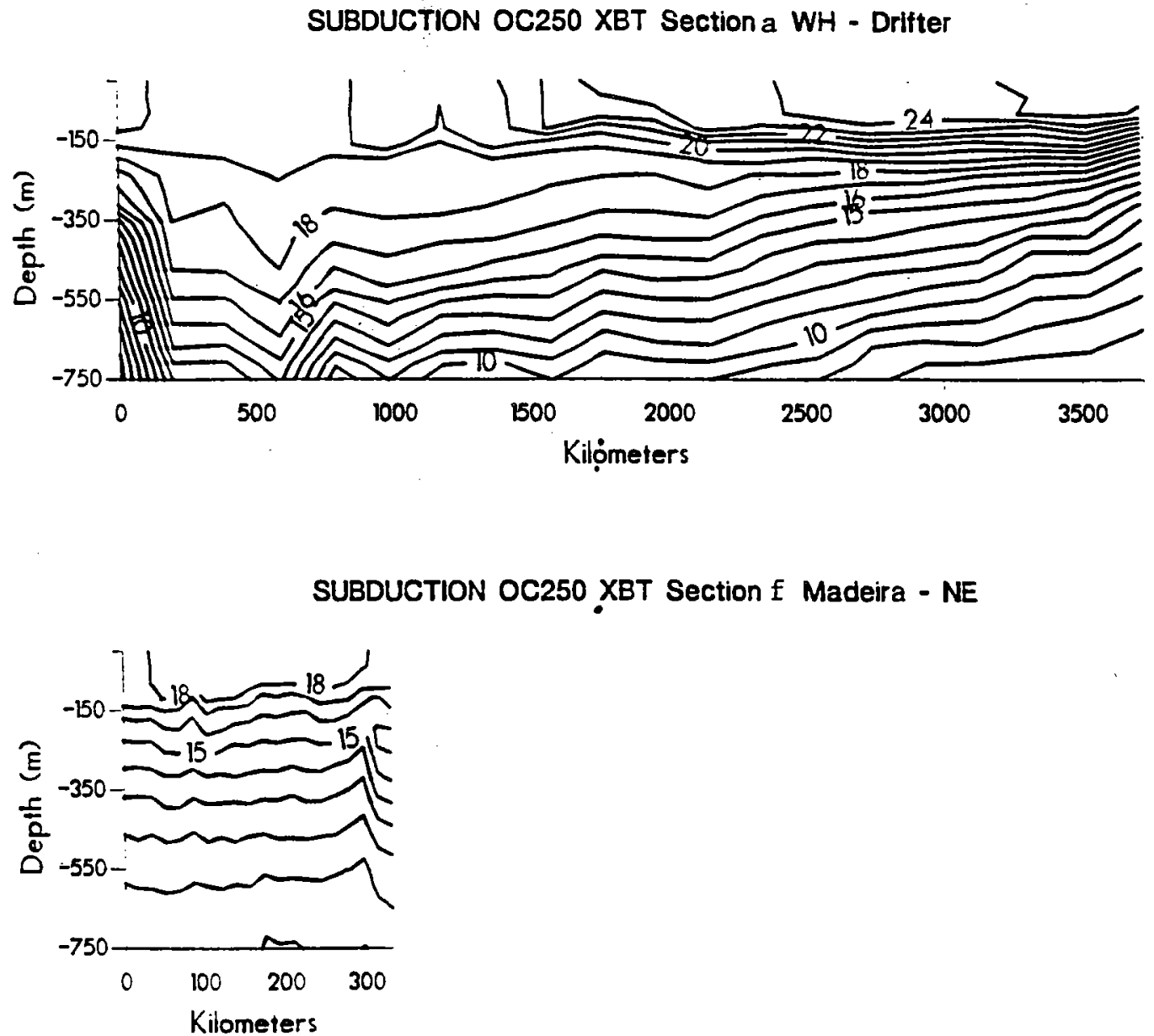

SUBDUCTION OC250 XBT Section h NW - Azores

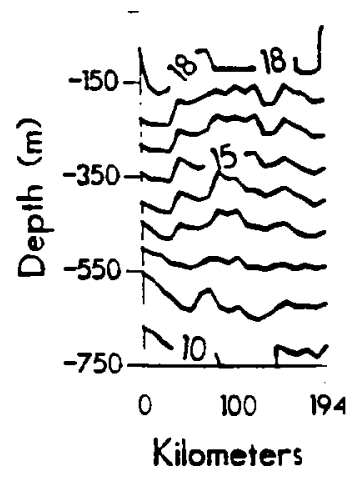




\section{Appendix 7 \\ IMET Shipbọard System Comparison with Manual Observations}

The following selected data were gathered on Oc-250 to compare the shipboard IMET system with manual observations taken by watch standers. The data are from the transit from Woods Hole to the Subduction SW buoy pickup site at $15^{\circ} 13^{\prime} \mathrm{N}, 44048^{\prime} \mathrm{W}$. Hand held meteorological measurements (dashed line) were made routinely during this time and compared to the IMET data (solid line). Within the accuracy limits of the hand held instruments and sampling locations on Oceanus, the correlation between the data sets is very good. Other short term comparisons between the Oceanus IMET and buoy IMET and VAWR were excellent. The IMET wind sensor measures wind direction relative to magnetic north and later processing will permit direction comparison plots from this unit. 
Figure A7-1. IMET Shipboard System Comparison with Manual Observations
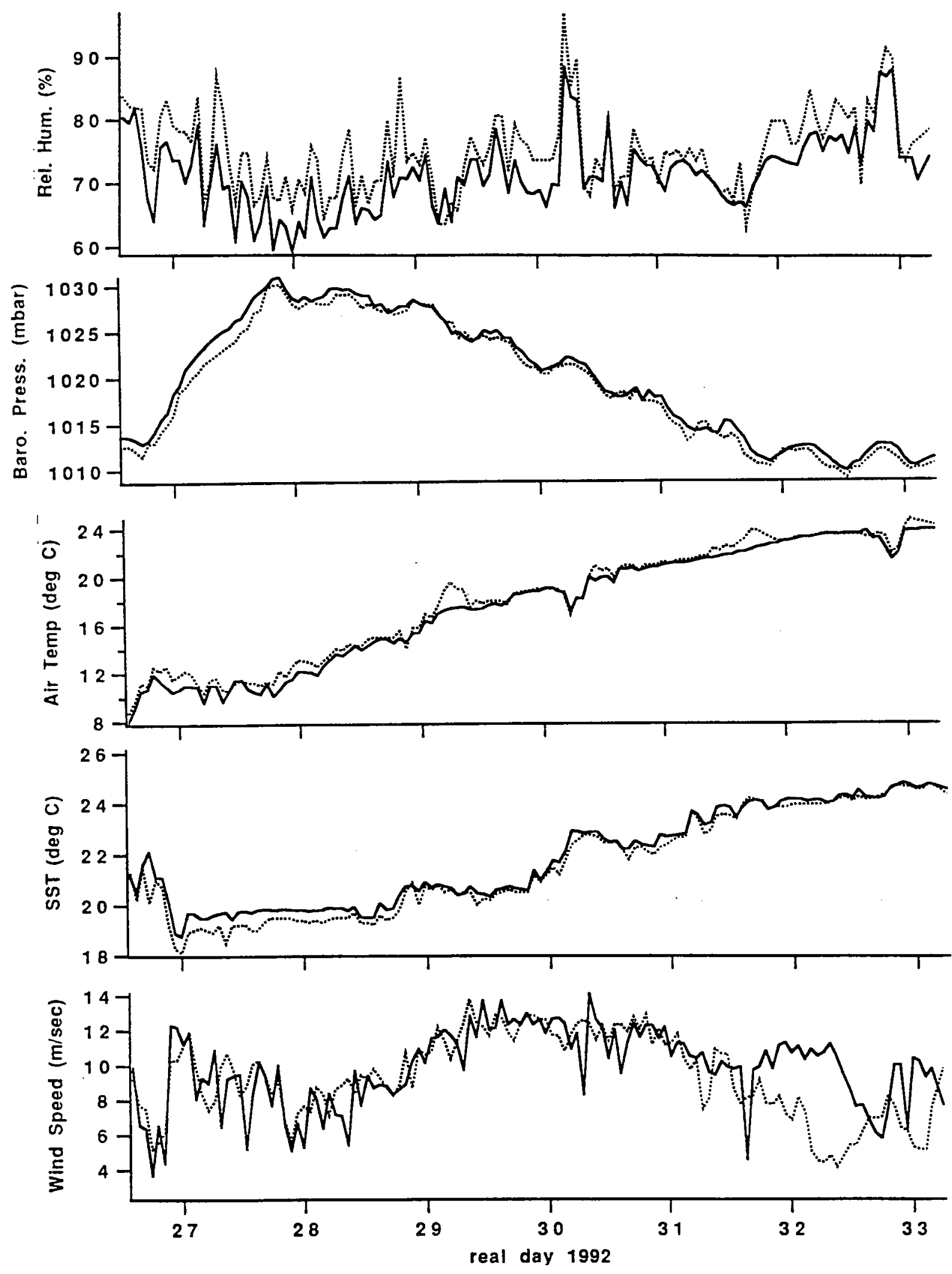


\section{Appendix 8}

\section{ADCP Data Files}

ADCP data was collected continuously during the Subduction II cruise. Processing and plotting of this data will take place in Woods Hole. Note that beginning with adcp.11, the pitch angle was set to 45 .

Data were collected on $51 / 4$ inch floppy diskettes.

Table A8-1

\begin{tabular}{llll} 
File & \multicolumn{2}{l}{ Creation Date and Time } & Size(bytes) \\
& & & \\
adcp.0 & Jan 25 & $15: 24$ & 320000 \\
adcp.1 & Jan 26 & $12: 14$ & 320256 \\
adcp.2 & Jan 27 & $09: 06$ & 320768 \\
adcp.3 & Jan 27 & $23: 16$ & 217856 \\
adcp.4 & Jan 28 & $20: 43$ & 320512 \\
adcp.5 & Jan 29 & $17: 33$ & 320256 \\
adcp.6 & Jan 30 & $14: 23$ & 320256 \\
adcp.7 & Jan 31 & $06: 38$ & 249856 \\
adcp.8 & Jan 31 & $12: 48$ & 93696 \\
adcp.9 & Feb 1 & $09: 38$ & 320256 \\
adcp.10 & Feb 2 & $05: 44$ & 308992 \\
adcp.11 & Feb 3 & $02: 40$ & 320256 \\
adcp.12 & Feb 3 & $23: 30$ & 320256 \\
adcp.13 & Feb 4 & $15: 40$ & 248576 \\
adcp.14 & Feb 5 & $12: 30$ & 320256 \\
adcp.15 & Feb 6 & $09: 20$ & 320256 \\
adcp.16 & Feb 7 & $06: 10$ & 320256 \\
adcp.17 & Feb 7 & $21: 55$ & 242176 \\
adcp.18 & Feb 8 & $18: 45$ & 320256 \\
adcp.19 & Feb 9 & $15: 35$ & 320256 \\
adcp.20 & Feb 10 & $12: 25$ & 320256 \\
adcp.21 & Feb 10 & $20: 55$ & 130816 \\
adcp.22 & Feb 11 & $17: 45$ & 320256 \\
adcp.23 & Feb 12 & $14: 35$ & 320256 \\
adcp.24 & Feb 13 & $11: 25$ & 320256 \\
adcp.25 & Feb 14 & $03: 40$ & 249856 \\
adcp.26 & Feb 15 & $00: 35$ & 320256 \\
adcp.27 & Feb 19 & $16: 40$ & 320768 \\
adcp.28 & Feb 19 & $19: 20$ & 320512 \\
adcp.29 & Feb 20 & $06: 25$ & 170496 \\
adcp.30 & Feb 21 & $03: 15$ & 320256 \\
adcp.31 & Feb 22 & $00: 05$ & 320256 \\
adcp.32 & Feb 22 & $20: 55$ & 320256 \\
adcp.33 & Feb 23 & $06: 50$ & 152576 \\
& & &
\end{tabular}




\section{Appendix 9 \\ Chronological Log of RV Oceanus Cruise 250}

Jan 25

01130

Jan 26

1400

1500

1600

Feb 2

0600

0631-0727

0730

0800

Feb 4

1158

$1430-1843$

1900

2200

Feb 5

1318

$1330-1530$

1747

1800

Feb 7

0949

1413

1630

Oceanus sails heading to drifting SW buoy - approx. $15 \mathrm{~N}, 45 \mathrm{~W}$

Underway watch begins

Hourly XBT started

Fire and Boat Drill

Arrive at drifting SW mooring

$15^{\circ} 13.09 \mathrm{~N}, 44^{\circ} 47.78 \mathrm{~W}$

Recover upper $110 \mathrm{~m}$ of mooring

Underway to SW anchor position

Start up XBT and met watch

On station for SW mooring recovery

Lower portion of the SW mooring recovered

Begin preparation for redeployment

Release test

Unspooling and respooling wire rope and nylon

Check for surface current

Begin deployment

Anchor over for Subduction II mooring SW $17^{\circ} 59.978^{\prime} \mathrm{N}, 34^{\circ} 00.513^{\prime} \mathrm{W}$

Intensive meteorological comparison

Underway to SE mooring

XBT and met watch started

Recovery of lower section of SE mooring

Release test

Begin preparation for redeployment

Unspooling and respooling wire rope and nylon

Check for surface currents

Feb 8-9

2241-0244

0315-0715

Deployment Subduction II SE

$17^{\circ} 59.72^{\prime} \mathrm{N}, 22^{\circ} 00.92^{\prime} \mathrm{W}$

0731-0846

0900

Intensive Met Observations by buoy

Release survey

1000

Underway to C

$\mathrm{XBT}$ and met watch resumed 
Feb 11

1040

$1044-1746$

1900
C Buoy sighted

Recover Central mooring

Begin preparation for redeployment

Unspooling and respooling wire rope and nylon

Checking for ship drift

\section{Feb 12}

1111-1916

2006-2049

Deployment Subduction II Central mooring $25^{\circ} 31.95^{\prime} \mathrm{N}, 28^{\circ} 57.23^{\prime} \mathrm{W}$

Release survey

\section{5-Feb 13}

0045

0100

0200

1319

Feb 14

0116

1328

2247

Intensive Meteorological observations

Underway to NE mooring

Resume underway met obs and XBTs

Deployed ALACE \# 46

$27^{\circ} 27.41^{\prime} \mathrm{N}, 27^{\circ} 06.98^{\prime} \mathrm{W}$

Deployed ALACE \#101

Deployed ALACE \#98

NE Buoy sighted

$29^{\circ} 24.140^{\prime} \mathrm{N}, 25^{\circ} 23.931^{\prime} \mathrm{W}$

$31^{\circ} 24.180^{\prime} \mathrm{N}, 23^{\circ} 30.533^{\prime} \mathrm{W}$

2352-Feb 15

0541

0605

NE mooring recovered

Underway to Madeira

\section{LEG 2}

Feb 19

0800

1000

Leaving Madeira Underway to NE deployment site

1200

Start underway meteorological observations

Start hourly XBT survey

$20 \mathrm{Feb}$

0600

0931-1547

$1747-2147$

2152

2200

2300

Approaching NE anchor site Deployment of Subduction II NE Mooring $33^{\circ} 01.98^{\prime} \mathrm{N}, 22^{\circ} 00.27^{\prime} \mathrm{W}$

Intensive Meteorological Observations

Underway to NW

Resume underway met watch

Resume hourly XBT watch

Feb 21

0413

1010

1613

1615

2211
Deploy ALACE \#100
Deploy ALACE \#97
Deploy ALACE \#103
Deploy ALACE with CTD \#59
Deploy ALACE \#102

$33^{\circ} 00.642^{\prime} \mathrm{N}, 23^{\circ} 28.465^{\prime} \mathrm{W}$

$32^{\circ} 59.368^{\prime} \mathrm{N}, 24^{\circ} 50.382^{\prime} \mathrm{W}$

$32^{\circ} 59.396^{\prime} \mathrm{N}, 26^{\circ} 13.393^{\prime} \mathrm{W}$

$32^{\circ} 59.396^{\prime} \mathrm{N}, 26^{\circ} 13.393^{\prime} \mathrm{W}$

$32^{\circ} 59.546^{\prime} \mathrm{N}, 27^{\circ} 34.365^{\prime} \mathrm{W}$ 
Feb 22

0411

1207

Deploy ALACE \#99

$32^{\circ} 58.331^{\prime} \mathrm{N}, 28^{\circ} 53.129^{\prime} \mathrm{W}$

Deploy ALACE \#44

$32^{\circ} 57.350^{\prime} \mathrm{N}, 30^{\circ} 38.513 \mathrm{~W}$

2006

Deploy ALACE \#96

$32^{\circ} 56.675^{\prime} \mathrm{N}, 32^{\circ} 25.669^{\prime} \mathrm{W}$

Feb 23

0941-1022

$1816-2328$

Recover bottom section of NW mooring

Deployment of Subduction II NW mooring $32^{\circ} 54.42^{\prime} \mathrm{N}, 33^{\circ} 53.35^{\prime} \mathrm{W}$

Feb 24

0024

0145-0545

0545

2000

Release Survey

Intensive Meteorological Observations

Underway to Ponta Delgada

Met and XBT watch suspended

Feb 26

0900

Arrive Ponta Delgada, Azores 


\section{DOCUMENT LIBRARY}

February 5, 1993

\section{Distribution List for Technical Report Exchange}

University of California, San Diego

SIO Library 0175C (TRC)

9500 Gilman Drive

La Jolla, CA 92093-0175

Hancock Library of Biology \& Oceanography

Alan Hancock Laboratory

University of Southern California

University Park

Los Angeles, CA 90089-0371

Gifts \& Exchanges

Library

Bedford Institute of Oceanography

P.O. Box 1006

Dartmouth, NS, B2Y 4A2, CANADA

Office of the International

Ice Patrol

c/o Coast Guard R \& D Center

Avery Point

Groton, CT 06340

NOAA/EDIS Miami Library Center

4301 Rickenbacker Causeway

Miami, FL 33149

Library

Skidaway Institute of Oceanography

P.O. Box 13687

Savannah, GA 31416

Institute of Geophysics

University of Hawaii

Library Room 252

2525 Correa Road

Honolulu, HI 96822

Marine Resources Information Center

Building E38-320

MIT

Cambridge, MA 02139

Library

Lamont-Doherty Geological

Observatory

Columbia University

Palisades, NY 10964

Library

Serials Department

Oregon State University

Corvallis, OR 97331
Pell Marine Science Library

University of Rhode Island

Narragansett Bay Campus

Narragansett, RI 02882

Working Collection

Texas A\&M University

Dept. of Oceanography

College Station, TX 77843

Fisheries-Oceanography Library

151 Oceanography Teaching Bldg.

University of Washington

Seattle, WA 98195

\section{Library}

R.S.M.A.S.

University of Miami

4600 Rickenbacker Causeway

Miami, FL 33149

Maury Oceanographic Library

Naval Oceanographic Office

Stennis Space Center

NSTL, MS 39522-5001

Marine Sciences Collection

Mayaguez Campus Library

University of Puerto Rico

Mayaguez, Puerto Rico 00708

Library

Institute of Oceanographic Sciences

Deacon Laboratory

Wormley, Godalming

Surrey GU8 5UB

UNITED KINGDOM

The Librarian

CSIRO Marine Laboratories

G.P.O. Box 1538

Hobart, Tasmania

AUSTRALIA 7001

Library

Proudman Oceanographic Laboratory

Bidston Observatory

Birkenhead

Merseyside L43 7 RA

UNITED KINGDOM

IFREMER

Centre de Brest

Service Documentation - Publications

BP 7029280 PLOUZANE

FRANCE 



\begin{tabular}{|c|c|c|}
\hline $\begin{array}{l}\text { REPORT DOCUMENTATION } \\
\text { PAGE }\end{array}$ & $\begin{array}{l}\text { 1. REPORT NO. } \\
\text { WHOI-93-13 }\end{array}$ & 3. Recipient's Accession No. \\
\hline \multirow{2}{*}{\multicolumn{2}{|c|}{$\begin{array}{l}\text { 4. Title and Subtitle } \\
\text { The Subduction Experiment - Cruise Report - R/V Oceanus - Cruise Number } 250 \text { Legs } 1 \text { and } \\
2 \text { - Subduction } 2 \text { Mooring Deployment and Recovery Cruise }\end{array}$}} & $\begin{array}{l}\text { 5. Report Date } \\
\text { March } 1993\end{array}$ \\
\hline & & 6. \\
\hline \multicolumn{2}{|c|}{$\begin{array}{l}\text { 7. Author(s) } \\
\text { Richard P. Trask, Nancy J. Brink, Lloyd Regier and Neil McPhee }\end{array}$} & $\begin{array}{l}\text { 8. Performing Organization Rept. No. } \\
\text { WHOI 93-13 }\end{array}$ \\
\hline \multirow{2}{*}{\multicolumn{2}{|c|}{$\begin{array}{l}\text { 9. Performing Organization Name and Address } \\
\text { The Woods Hole Oceanographic Institution } \\
\text { Woods Hole, Massachusetts } 02543\end{array}$}} & 10. Project/TaskWWork Unit No. \\
\hline & & $\begin{array}{l}\text { 11. Contract(C) or Grant(G) No. } \\
\text { (C) N00014-90-J-1490 } \\
\text { (G) }\end{array}$ \\
\hline \multirow{2}{*}{\multicolumn{2}{|c|}{$\begin{array}{l}\text { 12. Sponsoring Organization Name and Address } \\
\text { Funding was provided by the Office of Naval Research. }\end{array}$}} & $\begin{array}{l}\text { 13. Type of Report \& Period Covered } \\
\text { Technical Report }\end{array}$ \\
\hline & & 14. \\
\hline
\end{tabular}

\section{Supplementary Notes}

This report should be cited as: Woods Hole Oceanog. Inst. Tech. Rept., WHOI-93-13.

\section{Abstract (Limit: 200 words)}

Subduction is the mechanism by which water masses formed in the mixed layer and near the surface of the ocean find their way into the upper thermocline. The subduction process and its underlying mechanisms were studied through a combination of Eulerian and Langrangian measurements of velocity, measurements of tracer distributions and hydrographic properties and modeling.

An array of five surface moorings carrying meteorological and oceanographic instrumentation were deployed for a period of two years beginning in June 1991 as part of an Office of Naval Research (ONR) funded Subduction experiment. Three eight month deployments were planned. The initial deployment of five surface moorings took place during the third leg of R/V Oceanus cruise number 240. The moorings were deployed at $18^{\circ} \mathrm{N} 34^{\circ} \mathrm{W}, 18^{\circ} \mathrm{N} 22^{\circ} \mathrm{W}, 25.5^{\circ} \mathrm{N} 29^{\circ} \mathrm{W}, 33^{\circ} \mathrm{N} 22^{\circ} \mathrm{W}$ and $33^{\circ} \mathrm{N} 34^{\circ} \mathrm{W}$.

A Vector Averaging Wind Recorder (VAWR) and an Improved Meteorological Recorder (IMET) collected wind speed and wind direction, sea surface temperature, air temperature, short wave radiation, barometric pressure and relative humidity. The IMET also measured precipitation. The moorings were heavily instrumented below the surface with Vector Measuring Current Meters (VMCM) and single point temperature recorders.

Expendable bathythermograph (XBT) data were collected and meteorological observations were made while transitting between mooring locations.

This report describes the work that took place during R/V Oceanus cruise 250 which was the second scheduled Subduction mooring cruise. During this cruise the first setting of the moorings were recovered and redeployed for a second eight month period. This report includes a description of the instrumentation that was deployed and recovered, has information about the underway measurements (XBT and meteorological observations) that were made including plots of the data and presents a chronology of the cruise events.

\section{Document Analysis a. Descriptors}

1. air-sea interaction

2. moored instruments

3. subduction

b. Identifiers/Open-Ended Terms

c. COSATI Field/Group

18. Availability Statement

Approved for publication; distribution unlimited.

19. Security Class (This Report)

UNCLASSIFIED

20. Security Class (This Page)
21. No. of Pages

106

22. Price 
